\title{
Retention Strategies for Medications for Addiction Treatment in Adults With Opioid Use Disorder: A Rapid Evidence Review
}




\title{
Retention Strategies for Medications for Addiction Treatment in Adults With Opioid Use Disorder: A Rapid Evidence Review
}

\author{
Prepared for: \\ Agency for Healthcare Research and Quality \\ U.S. Department of Health and Human Services \\ 5600 Fishers Lane \\ Rockville, MD 20857 \\ www.ahrq.gov
}

Contract No HHSA 290-2017-00003C

Prepared by:

Scientific Resource Center

Portland, OR

Investigators:

Brian Chan, M.D., M.P.H.

Emily Gean, Ph.D.

Irina Arkhipova-Jenkins, M.D., M.B.A.

Jennifer Gilbert, M.D., M.P.H.

Jennifer Hilgart, M.Sc.

Celia Fiordalisi, M.S.

Kimberly Hubbard, B.A.

Irene Brandt, M.A.

Elizabeth Stoeger, B.S.

Robin Paynter, M.L.I.S.

P. Todd Korthuis, M.D., M.P.H.

Jeanne-Marie Guise, M.D., M.P.H.

AHRQ Publication No. 20-EHC012

July 2020

Errata August 2020 
This report is based on research conducted by the Scientific Resource Center under contract to the Agency for Healthcare Research and Quality (AHRQ), Rockville, MD (Contract No. 290-2017-00003-C). The findings and conclusions in this document are those of the authors, who are responsible for its contents; the findings and conclusions do not necessarily represent the views of AHRQ. Therefore, no statement in this report should be construed as an official position of AHRQ or of the U.S. Department of Health and Human Services.

\section{None of the investigators have any affiliations or financial involvement that conflicts with the material presented in this report.}

The information in this report is intended to help health care decision makers-patients and clinicians, health system leaders, and policymakers, among others-make well-informed decisions and thereby improve the quality of health care services. This report is not intended to be a substitute for the application of clinical judgment. Anyone who makes decisions concerning the provision of clinical care should consider this report in the same way as any medical reference and in conjunction with all other pertinent information, i.e., in the context of available resources and circumstances presented by individual patients.

This report is made available to the public under the terms of a licensing agreement between the author and the Agency for Healthcare Research and Quality. This report may be used and reprinted without permission except those copyrighted materials that are clearly noted in the report. Further reproduction of those copyrighted materials is prohibited without the express permission of copyright holders.

AHRQ or U.S. Department of Health and Human Services endorsement of any derivative products that may be developed from this report, such as clinical practice guidelines, other quality enhancement tools, or reimbursement or coverage policies, may not be stated or implied.

Suggested citation: Chan B, Gean E, Arkhipova-Jenkins I, Gilbert J, Hilgart J, Fiordalisi C, Hubbard K, Brandt I, Stoeger E, Paynter R, Korthuis PT, Guise J-M. Retention Strategies for Medications for Addiction Treatment in Adults With Opioid Use Disorder: A Rapid Evidence Review. (Prepared by the Scientific Resource Center under Contract No. HHSA 290-201700003C). AHRQ Publication No. 20-EHC012. Rockville, MD: Agency for Healthcare Research and Quality. July 2020. Errata August 2020. Posted final reports are located on the Effective Health Care Program search page.

DOI: https://doi.org/10.23970/AHRQEPCRAPIDMAT. 


\section{Errata}

In the original version of this report, there was an omission with respect to the search strategy. Specifically, following the reported primary search conducted on June16, 2019, that included studies published between February 12, 2009, and June 16, 2019, we conducted a "gap search" on August 20, 2019, which was not reported in the original version of the report. No additional included studies were identified from this gap search. We have updated the search strategies portion of the Methods sections of the abstract, evidence summary, and main report to reflect the gap search and updated the Results section of the main report to indicate that no new included studies were identified. 


\section{Preface}

Recognized for excellence in conducting comprehensive systematic reviews, the Agency for Healthcare Research and Quality (AHRQ) Evidence-based Practice Center (EPC) program is expanding its portfolio to include rapid evidence products. The program has begun to develop a range of rapid evidence products to assist end-users in making specific decisions in a limited timeframe.

In 2014, AHRQ EPCs produced a taxonomy of rapid evidence products produced by leading organizations around the world. ${ }^{1-4}$ This taxonomy now informs the development of rapid evidence products. Based on levels of synthesis, the report classified products as evidence inventories, rapid responses, and rapid reviews. On one end of the spectrum, evidence inventories offer an assessment of the quantity and type of evidence without presenting results. On the other end, rapid reviews adapt and streamline traditional systematic review methods to provide a limited evidence synthesis. Rapid responses fall between the two; through examination of the literature but no formal evidence synthesis or conclusion, rapid responses aim to offer the end-user a solution to a targeted problem based on the best available evidence.

To shorten timelines, reviewers must make strategic choices about which processes to abridge. Common adaptations to provide rapid evidence include: narrowly focusing questions, limiting the number of databases searched and/or modifying search strategies, using a single reviewer and/or abstractor with a second to provide verification, and restricting to studies published in the English language. However, the adaptations made for expediency may limit the certainty and generalizability of the findings from the review, particularly in areas with a large literature base. Transparent reporting of the methods used, the resulting limitations of the evidence synthesis, and the strength of evidence of included studies is extremely important. While tradeoffs will likely differ for each topic, they are described so readers can adjudicate the limitations of the findings and conclusions of the review.

While rapid evidence products are often sufficient for decision making on their own, at other times they can uncover a large, complex literature base that encourages end-users to seek a full review. Rapid evidence products can provide a map of the evidence and assist decisionmakers in targeting resources to areas of highest interest and greatest potential value.

AHRQ expects that these rapid evidence products will be helpful to health plans, providers, purchasers, government programs, and the health care system as a whole. Transparency and stakeholder input are essential to the Effective Health Care Program.

If you have comments on this report, they may be sent by mail to the Task Order Officer named below at: Agency for Healthcare Research and Quality, 5600 Fishers Lane, Rockville, MD 20857, or by email to epc@ahrq.hhs.gov. 
Gopal Khanna, M.B.A.

Director

Agency for Healthcare Research and Quality

Stephanie Chang, M.D., M.P.H.

Director

Evidence-based Practice Center Program

Center for Evidence and Practice Improvement

Agency for Healthcare Research and Quality
Arlene Bierman, M.D., M.S.

Director

Center for Evidence and Practice Improvement

Agency for Healthcare Research and Quality

Christine Chang, M.D., M.P.H.

Task Order Officer

Center for Evidence and Practice

Improvement

Agency for Healthcare Research and Quality

\section{References}

1. Hartling L, Guise J-M, Kato E, et al. EPC Methods: An Exploration of Methods and Context for the Production of Rapid Reviews. Rockville (MD): 2015. https://www.ncbi.nlm.nih.gov/pubmed/25654160.

2. Hartling L, Guise J-M, Kato E, et al. A taxonomy of rapid reviews links report types and methods to specific decision-making contexts. J Clin Epidemiol. 2015;68(12):1451-62.e3. PMID: 26278023.

3. Hartling L, Guise J-M, Hempel S, et al. EPC methods: AHRQ End-user perspectives of rapid reviews. Rockville (MD): 2016. https://www.ncbi.nlm.nih.gov/pubmed/27195347.

4. Hartling L, Guise J-M, Hempel S, et al. Fit for purpose: perspectives on rapid reviews from end-user interviews. Systematic Reviews. 2017;6:32. doi: 10.1186/s13643-017-0425-7. PMID: PMC5316162. 


\section{Acknowledgments}

The authors gratefully acknowledge the following individuals for their contributions to this project:

Linda Humphrey, M.D., M.P.H.

Ed Reid, M.S., M.A.T, M.F.A.

Allison Schmidt, M.S.

Mark Helfand, M.D., M.S., M.P.H.

\section{Peer Reviewers}

Prior to publication of the final evidence report, EPCs sought input from independent Peer Reviewers without financial conflicts of interest. However, the conclusions and synthesis of the scientific literature presented in this report does not necessarily represent the views of individual reviewers.

Peer Reviewers must disclose any financial conflicts of interest greater than $\$ 5,000$ and any other relevant business or professional conflicts of interest. Because of their unique clinical or content expertise, individuals with potential nonfinancial conflicts may be retained. The TOO and the EPC work to balance, manage, or mitigate any potential nonfinancial conflicts of interest identified.

The list of Peer Reviewers follows:

Gerald Gartlehner, M.D., M.P.H.

Associate Director

RTI-University of North Carolina at Chapel Hill Evidence-based Practice Center

Chapel Hill, NC

Paula J. Lum, M.D., M.P.H.

Professor of Clinical Medicine

HIV, ID and Global Medicine Division

Department of Medicine

University of California, San Francisco

San Francisco, CA 


\section{Retention Strategies for Medications for Addiction Treatment in Adults With Opioid Use Disorder: A Rapid Evidence Review}

\section{Structured Abstract}

Aims. American deaths from opioid overdose now approach 50,000 annually. While evidence shows that medications for addiction treatment (MAT) save lives, retaining patients in MAT programs is challenging. The U.S. Agency for Healthcare Research and Quality, on behalf of the U.S. Department of Health and Human Services, commissioned a rapid evidence review on the effectiveness of interventions to promote a broader understanding of the published literature on MAT retention among adults with opioid use disorder (OUD).

Methods. We searched MEDLINE and the Cochrane Library from February 12, 2009, through August 20, 2019, for systematic reviews (SRs) and randomized controlled trials (RCTs). We summarized evidence for six retention intervention types: care settings/services/logistical support, contingency management, health information technology (IT), extended-release (XR) medication-based treatment, psychosocial support, and financial support. Our primary outcome was retention, defined as continued medication engagement for at least 3 months after MAT initiation. Secondary outcomes included mortality and harms.

Findings. Key findings from 2 SRs and 39 primary studies include:

- Most studies of MAT for OUD do not focus on retention as the primary outcome, are small (e.g., one to two trials per intervention), and have design flaws.

- Care setting interventions that initiated MAT in soon-to-be-released incarcerated patients improved retention following release.

- Contingency management improved retention when combined with antagonist MAT, but not with agonist forms of MAT. Applicability, however, may be limited due to implementation challenges.

- Preliminary trials suggest that retention in MAT supported with health IT approaches may be no worse than in-person approaches.

- Early studies suggest no difference in retention with XR-buprenorphine in either injectable or implant formulations compared with daily buprenorphine. There were conflicting results with XR-naltrexone injection compared with daily buprenorphine.

- The addition of psychosocial interventions did not improve retention; however, many studies included some form of counseling in the control groups, potentially obscuring evidence of effectiveness.

Harms were infrequently reported across studies except in studies of XR formulations. Similarly, few studies reported whether participant characteristics influenced retention.

Conclusions. While patients who receive longer-term treatment with MAT have improved outcomes, fewer than half of the identified studies measured treatment retention as a primary outcome. Limited evidence suggests criminal justice prerelease MAT initiation and the use of contingency management for patients on antagonist forms of MAT may aid retention. XR 
and daily buprenorphine formulations appear to be equivalent for treatment retention and comparisons of XR-naltrexone versus daily buprenorphine showed conflicting results.

Integrating MAT treatment with medical and social services and the use of health IT did not change retention. Some studies were conducted outside of the United States, where policies and practices differ, focused on highly selected populations and/or conditions that are not fully representative of the spectrum of OUD, or were studied in situations that may not be easily implemented in real-world conditions. There is a critical need for studies that use standardized definitions of retention, include measures of harms as well as benefits, and reflect the full spectrum of real-life conditions. 


\section{Contents}

Evidence Summary ................................................................................................................................ ES-1

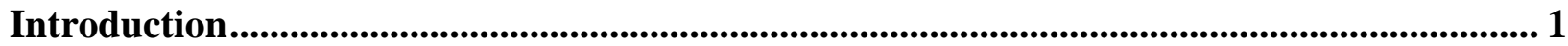

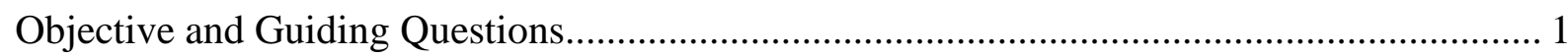

Methods........................................................................................................................................... 2

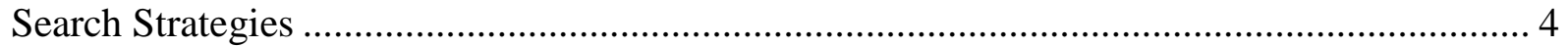

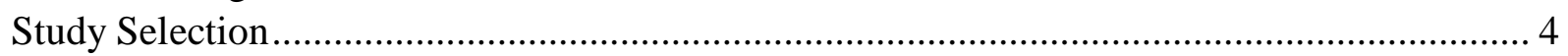

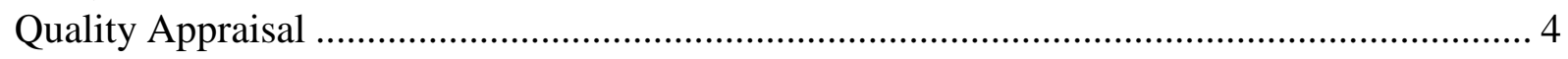

Data Collection and Synthesis....................................................................................... 5

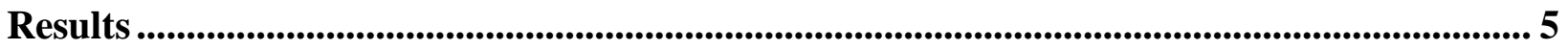

Care Settings, Services, and Logistical Support........................................................................ 7

Care Setting: MAT for Soon-To-Be-Released Incarcerated Populations ............................ 7

Care Setting: Integration of MAT With Psychiatric and Primary Care Services ............... 8

Care Setting: MAT in ED/Hospital Settings .................................................................... 8

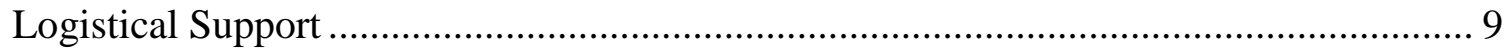

Contingency Management................................................................................................. 10

Health Information Technology …………………….................................................... 11

Commercially Available Mobile Apps ……………………......................................... 14

Extended-Release Medication-Based Treatment for OUD ....................................................... 14

Psychosocial Support ……………………………….................................................... 16

Financial Support ……………………………………............................................... 17

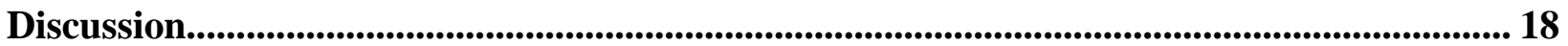

Care Settings/Services/Logistical Support ............................................................................ 18

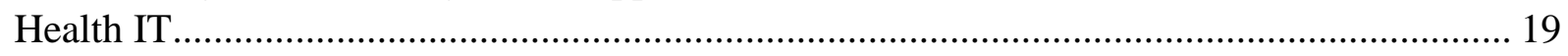

Extended-Release Medication-Based Treatment for OUD ........................................................ 20

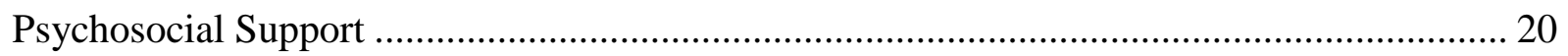

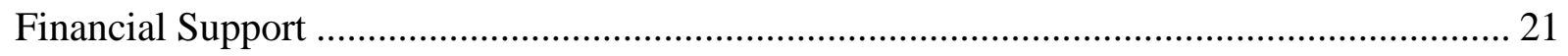

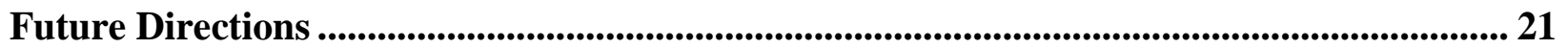

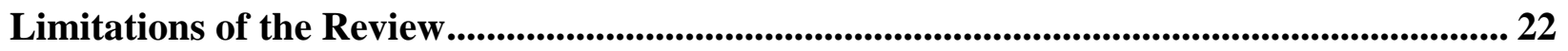

Conclusions...................................................................................................................................... 22

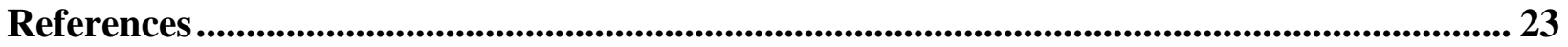

Abbreviations and Acronyms .......................................................................................................... 29

\section{Tables}

Table A. Summary of findings by intervention type ............................................................. ES-2

Table 1. Inclusion and exclusion criteria .................................................................................. 3

Table 2. Summary of findings for care settings / services / logistical support ................................. 7

Table 3. Summary of findings for contingency management ....................................................... 10

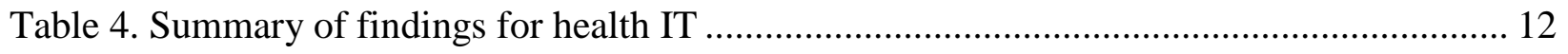

Table 5a. Summary for extended-release versus daily MAT formulations within the same agonist/antagonist drug categories 
Table 5b. Summary for extended-release versus daily MAT formulations across different agonist/antagonist categories .................................................................................................. 15

Table 6. Summary of findings for psychosocial interventions ................................................... 16

Figures

Figure 1. Analytic framework for improving retention in MAT for OUD ................................. 2

Figure 2. Literature flow diagram ................................................................................ 6

Figure 3. Spectrum of IT interventions proposed to increase MAT retention............................ 12

\section{Appendixes}

Appendix A. Search Strategy

Appendix B. Data Tables

Appendix C. Quality Rating Tables 


\section{Evidence Summary}

\section{Main Points}

- Most studies of medications for addiction treatment (MAT) for opioid-use disorder (OUD) do not focus on retention as the primary outcome, are small (e.g., one to two trials per intervention), and have design flaws.

- Care setting interventions that initiated MAT in soon-to-be-released incarcerated patients improved retention following release.

- Contingency management (CM) improved retention when combined with antagonist, but not with agonist, forms of MAT. Applicability, however, may be limited due to implementation challenges.

- Preliminary trials suggest that retention in MAT supported with health information technology (IT) approaches may be no worse than in-person approaches.

- Early studies suggest no difference in retention with XR-buprenorphine in either injectable or implant formulations compared with daily buprenorphine. There were conflicting results with XR-naltrexone injection compared with daily buprenorphine.

\section{Background and Purpose}

To help inform policy across the Department of Health and Human Services, we conducted a rapid evidence review on the effectiveness of interventions to improve MAT retention among OUD patients to inform a broader understanding of the published literature. While evidence indicates that MAT programs are effective and save lives, retention rates are low. The review focused on nonpregnant adults with OUD.

\section{Methods}

This review followed recommendations from the World Health Organization handbook ${ }^{2}$ rapid review methodology and abridged systematic review (SR) processes. Our searches covered publication dates from February 12, 2009 to August 20, 2019. We describe our methods in detail in the full report. The protocol can be found at: [https://effectivehealthcare.ahrq.gov/topics/mat-retention-strategies-oud/rapid-protocol].

\section{Results}

Our search retrieved 1,580 unique titles and abstracts from which we reviewed 258 full-text articles and included 2 SRs and 39 unique primary studies. A partial summary of findings includes the following. 
Table A. Summary of findings by intervention type

\begin{tabular}{|c|c|c|c|c|c|c|}
\hline & Intervention & Comparator & $\begin{array}{c}\text { Number of } \\
\text { Studies }\end{array}$ & $\begin{array}{l}\text { Number of } \\
\text { Participants }\end{array}$ & $\begin{array}{l}\text { Quality of } \\
\text { Evidence }\end{array}$ & $\begin{array}{l}\text { Summary of } \\
\text { Retention } \\
\text { Results }\end{array}$ \\
\hline \multirow[t]{4}{*}{$\begin{array}{l}\text { Care } \\
\text { Settings, } \\
\text { Services, } \\
\text { Logistical } \\
\text { Support }\end{array}$} & $\begin{array}{l}\text { MAT for } \\
\text { soon-to-be-released } \\
\text { incarcerated } \\
\text { populations }\end{array}$ & $\begin{array}{l}\text { No MAT } \\
\text { in prison }\end{array}$ & $\begin{array}{l}1 \mathrm{SR}^{1}+ \\
2 \text { additional } \\
\mathrm{RCTS}^{2,3}\end{array}$ & $\begin{array}{l}\text { SR: } n=834 \\
\text { (range: } \\
\text { 32-446) } \\
\\
2 \text { RCTs: } \\
\text { n=228 (15 } \\
\text { and 213) }\end{array}$ & $\begin{array}{l}\text { SR: good; } \\
1 \text { fair; } \\
1 \text { poor }\end{array}$ & $\begin{array}{l}\text { Benefit with } \\
\text { prerelease MAT } \\
\text { in all studies }\end{array}$ \\
\hline & $\begin{array}{l}\text { Psychiatric \& } \\
\text { primary care } \\
\text { (PC) services }\end{array}$ & $\begin{array}{l}\text { Specialty } \\
\text { outpatient } \\
\text { setting }\end{array}$ & $3 \mathrm{RCTS}^{4-6}$ & $\begin{array}{l}\mathrm{n}=631 \\
\text { (range: } \\
94-316)\end{array}$ & 3 fair & $\begin{array}{l}\text { Inconsistent } \\
\text { ( } 2 \text { psychiatric } \\
\text { studies, benefit } \\
\text { in one and no } \\
\text { difference from } \\
\text { traditional setting } \\
\text { in other; } 1 \text { study } \\
\text { in PC, no } \\
\text { difference from } \\
\text { traditional } \\
\text { setting) }\end{array}$ \\
\hline & $\begin{array}{l}\text { Emergency } \\
\text { department } \\
\text { (ED)/hospital setting }\end{array}$ & TAU & $2 \mathrm{RCTs}^{7,8}$ & $\begin{array}{l}n=429 \\
(139 \text { and } \\
290)\end{array}$ & 2 fair & $\begin{array}{l}\text { ED no worse } \\
\text { than traditional } \\
\text { (1 study with no } \\
\text { difference; } \\
1 \text { study with } \\
\text { benefit for } \\
\text { hospital-initiated } \\
\text { MAT) }\end{array}$ \\
\hline & Logistical support & TAU & $4 \mathrm{RCTs}^{9-12}$ & $\begin{array}{l}\mathrm{n}=709 \\
\text { (range: } \\
97-300)\end{array}$ & $\begin{array}{l}1 \text { good; } \\
3 \text { fair }\end{array}$ & No difference \\
\hline \multirow[t]{2}{*}{$\begin{array}{l}\text { Contingency } \\
\text { Management }\end{array}$} & $\begin{array}{l}\text { Opioid receptor } \\
\text { antagonist MAT }\end{array}$ & $\begin{array}{l}\text { Noncontingent } \\
\text { access to a } \\
\text { reward }\end{array}$ & 3 RCTs $^{13-15}$ & $\begin{array}{l}n=140 \\
\text { (range: } \\
35-67)\end{array}$ & 3 fair & $\begin{array}{l}\text { Benefit for CM } \\
\text { in all studies }\end{array}$ \\
\hline & $\begin{array}{l}\text { Opioid receptor } \\
\text { agonist/partial } \\
\text { agonist MAT }\end{array}$ & $\begin{array}{l}\text { Noncontingent } \\
\text { access to a } \\
\text { reward }\end{array}$ & $\begin{array}{l}1 \mathrm{SR}^{\star 16}+ \\
4 \text { additional } \\
\mathrm{RCTS}^{11,17-19}\end{array}$ & $\begin{array}{l}\text { SR: } n=1616 \\
\text { 4 RCTs: } \\
\text { n=698 } \\
\text { (range: } \\
\text { 98-252) }\end{array}$ & $\begin{array}{l}\text { SR: good; } \\
1 \text { good; } \\
3 \text { fair }\end{array}$ & No difference \\
\hline
\end{tabular}




\begin{tabular}{|c|c|c|c|c|c|c|}
\hline & Intervention & Comparator & $\begin{array}{c}\text { Number of } \\
\text { Studies }\end{array}$ & $\begin{array}{l}\text { Number of } \\
\text { Participants }\end{array}$ & $\begin{array}{l}\text { Quality of } \\
\text { Evidence }\end{array}$ & $\begin{array}{l}\text { Summary of } \\
\text { Retention } \\
\text { Results }\end{array}$ \\
\hline \multirow[t]{3}{*}{ Health IT } & Telehealth & TAU & $\begin{array}{l}3 \text { cohort } \\
\text { studies }^{20-22}\end{array}$ & $\begin{array}{l}n=3965 \\
\text { (range: } \\
55-3733 \text { ) }\end{array}$ & 3 fair & $\begin{array}{l}\text { Telehealth no } \\
\text { worse than } \\
\text { in-person } \\
\text { (2 studies with } \\
\text { no difference, } \\
1 \text { study with } \\
\text { benefit for } \\
\text { telehealth) }\end{array}$ \\
\hline & $\begin{array}{l}\text { Computer-based } \\
\text { education \&/or } \\
\text { support }\end{array}$ & TAU & $3 \mathrm{RCTs}^{23-25}$ & $\begin{array}{l}n=262 \\
\text { (range: } \\
20-160)\end{array}$ & $\begin{array}{l}2 \text { fair; } \\
1 \text { poor }\end{array}$ & No difference \\
\hline & $\begin{array}{l}\text { Multicomponent } \\
\text { mobile and } \\
\text { computer-based } \\
\text { program }\end{array}$ & TAU & $1 \mathrm{RCT}^{26}$ & $n=1426$ & 1 fair & No difference \\
\hline \multirow{4}{*}{$\begin{array}{l}\text { Extended- } \\
\text { Release } \\
\text { Medication- } \\
\text { Based } \\
\text { Treatments }\end{array}$} & $\begin{array}{l}\text { Naltrexone } \\
\text { extended-release } \\
\text { 1-month injection }\end{array}$ & Daily naltrexone & $1 \mathrm{RCT}^{27}$ & $n=60$ & 1 fair & $\begin{array}{l}\text { Benefit for } \\
\text { XR injection }\end{array}$ \\
\hline & $\begin{array}{l}\text { Buprenorphine } \\
\text { extended-release } \\
\text { 1-month injection }\end{array}$ & $\begin{array}{l}\text { Daily SL- } \\
\text { buprenorphine/ } \\
\text { naloxone }\end{array}$ & $1 \mathrm{RCT}^{28}$ & $n=428$ & 1 fair & No difference \\
\hline & $\begin{array}{l}\text { Buprenorphine } \\
\text { extended-release } \\
6 \text {-month implant }\end{array}$ & $\begin{array}{l}\text { Daily SL- } \\
\text { buprenorphine }\end{array}$ & $1 \mathrm{RCT}^{29}$ & $n=177$ & $1 \mathrm{good}$ & No difference \\
\hline & $\begin{array}{l}\text { Naltrexone } \\
\text { extended-release } \\
\text { 1-month injection }\end{array}$ & $\begin{array}{l}\text { Daily SL- } \\
\text { buprenorphine/ } \\
\text { naloxone }\end{array}$ & $2 \mathrm{RCTs}^{30,31}$ & $\begin{array}{l}n=729 \\
(159 \text { and } \\
570)\end{array}$ & $\begin{array}{l}1 \text { good; } \\
1 \text { fair }\end{array}$ & $\begin{array}{l}\text { Inconsistent } \\
\text { (1 study no } \\
\text { difference, } \\
1 \text { study with } \\
\text { benefit for SL- } \\
\text { buprenorphine/ } \\
\text { naloxone) }\end{array}$ \\
\hline $\begin{array}{l}\text { Psychosocial } \\
\text { Support }\end{array}$ & $\begin{array}{l}\text { Including } \\
\text { behavioral, } \\
\text { psychoanalytic, and } \\
\text { counseling } \\
\text { interventions }\end{array}$ & TAU & $\begin{array}{l}1 \mathrm{SR}^{\star 16}+ \\
9 \text { additional } \\
\mathrm{RCTS}^{32-40}\end{array}$ & $\begin{array}{l}\text { SR: } n=3124 \\
\text { (range: } \\
\text { 14-542) } \\
\\
9 \text { RCTs: } \\
\text { n=2483 } \\
\text { (range: } \\
\text { 49-653) }\end{array}$ & $\begin{array}{l}\text { SR: good } \\
2 \text { good; } \\
4 \text { fair; } \\
3 \text { poor }\end{array}$ & $\begin{array}{l}\text { No difference } \\
\text { in all but } \\
\text { one poor-quality } \\
\text { study. Many of } \\
\text { the studies } \\
\text { reviewed } \\
\text { included some } \\
\text { form of } \\
\text { counseling in the } \\
\text { control groups. }\end{array}$ \\
\hline
\end{tabular}

$\mathrm{CM}=$ contingency management; IT=information technology; MAT=medications for addiction treatment; RCT=randomized controlled trial; $\mathrm{SL}=$ sublingual; $\mathrm{SR}=$ systematic review; TAU=treatment as usual; $\mathrm{XR}=$ extended-release

*SR applicable to two intervention types 


\section{Limitations}

We were not able to address every intervention proposed to improve retention in MAT. We did not review studies of potentially promising interventions that used non-MAT comparator groups. Measures of retention varied amongst studies, making comparisons difficult.

\section{Implications and Conclusions}

According to the National Academy of Medicine, patients who receive longer-term treatment with medication for OUD have better outcomes and are less likely to die from overdose; however, fewer than half of the studies identified in this report focused on treatment retention as a primary outcome. Initiating MAT in soon-to-be-released criminal justice populations and the use of CM for people on antagonist MAT may improve retention, although there may be challenges to implementing CM interventions in real-world contexts. MAT treatment programs that include the use of health IT may be equally as effective as those delivered using traditional, exclusively in-person approaches. Studies of XR versus daily buprenorphine formulations showed similar treatment retention, and, while comparisons between XR-naltrexone injection and daily buprenorphine yielded inconclusive findings, additional comparative effectiveness trials are underway. Future research should focus on treatment retention as a primary outcome, use standardized measures of retention, report treatment harms as well as benefits, and consider the effects of participant characteristics on the effectiveness of strategies to improve retention in MAT. 


\section{Introduction}

The United States is in the midst of an opioid crisis. In 2017, 2.1 million Americans 12 years and older met diagnostic criteria for opioid use disorder (OUD) ${ }^{41}$ and 47,600 people died from an opioid-involved overdose. ${ }^{42,43}$ In addition to overdose deaths, OUD is associated with increased rates of comorbid conditions including HIV, hepatitis C, serious bacterial infections, mental health disorders, and other substance use disorders (SUDs). ${ }^{43}$

There is clear evidence, including a recent report from the National Academies of Science, Engineering, and Medicine (NASEM), that medications for addiction treatment (MAT) retention improve outcomes. ${ }^{44-46}$ The U.S. Food and Drug Administration (FDA) has approved three medications - methadone, buprenorphine, and extended-release (XR)-naltrexone-for treatment of OUD. ${ }^{47}$ Despite evidence that these medications successfully treat OUD, intermediate and long-term retention of patients on MAT remains challenging and highly variable, with retention at 3 months ranging from 19 percent to 94 percent. ${ }^{48}$ Potential explanations for the wide variation in retention include-

- Barriers for access to MAT

- Stigma associated with medications

- Costs and logistical issues with obtaining and maintaining medications

- Undertreatment of comorbid psychiatric and medical conditions ${ }^{49}$

- Fragmented systems of care for people with OUD

- Current SUD financing and coverage policies ${ }^{44}$

- Coercion into treatment of people not actively seeking treatment (e.g., drug court settings)

Improving MAT retention can decrease unnecessary deaths. ${ }^{50,51}$ Successfully addressing the opioid crisis will require the American health system to identify, apply, and improve interventions that promote MAT retention.

The U.S. Agency for Healthcare Research and Quality (AHRQ) commissioned this rapid review on behalf of the U.S. Department of Health and Human Services (HHS) agencies to provide an overview of the published literature to assist the offices in research, practice, and policy decision making around strategies to improve MAT retention. HHS partners include the Office of the Assistant Secretary for Health, Center for Drug Evaluation and Research at FDA, the Office of the Assistant Secretary for Mental Health and Substance Use for the Substance Abuse and Mental Health Services Administration (SAMHSA), the Division of Unintentional Injury Prevention in the National Center for Injury Prevention and Control at the Centers for Disease Control and Prevention, the Office of the Assistant Secretary for Planning and Evaluation, the National Institute on Drug Abuse (NIDA) at the National Institutes of Health (NIH), and the Health Resources and Services Administration.

\section{Objective and Guiding Questions}

Our objective was to rapidly identify and summarize latest evidence on interventions to improve MAT retention among adults with OUD in order to inform policy priorities and future research directions. The following questions guided the literature search and inclusion/exclusion criteria:

Key Question 1: What are the effectiveness and comparative effectiveness of strategies to improve retention in MAT among nonpregnant adults with OUD? 
Key Question 2: What are the harms of retention strategies for MAT?

Key Question 3: Does the effectiveness of the MAT retention strategy vary by participant characteristics (e.g., age, gender/sex, socioeconomic status, geographic region, polysubstance use)?

We developed an analytic framework (Figure 1) in consultation with our stakeholders to guide our approach.

Figure 1. Analytic framework for improving retention in MAT for OUD

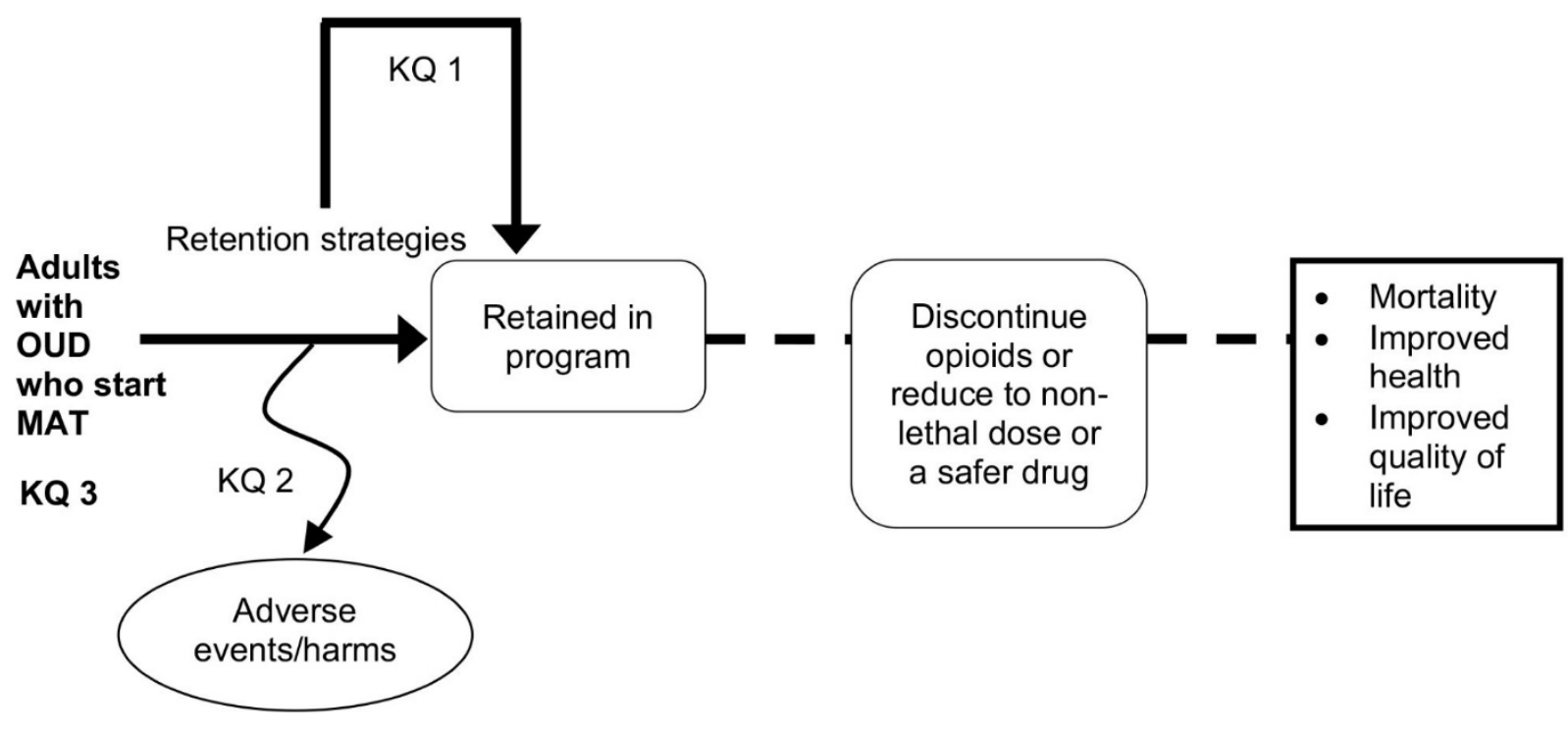

\section{Methods}

This review followed recommendations from the World Health Organization (WHO) handbook rapid review methodology ${ }^{52}$ and abridged systematic review (SR) processes in the following ways:

- Introduction.

- Focused on limited number of topics that were highest priority for partners.

- Searched a limited number of databases.

- One reviewer independently reviewed titles, abstracts, and papers for inclusion with 25 percent independent review by a second reviewer. Disagreements were resolved by group consensus.

- One reviewer abstracted information with second verification.

- Truncated inclusion criteria (Table 1) to include studies:

o Published in English language

o Published in the last 10 years 
o Populations of nonpregnant adults with OUD (excluded studies of HIV, other substance use, etc., unless focus was primarily OUD)

o Focused on retention in MAT (rather than abstinence)

- Main focus on SRs and comparative randomized controlled trials (RCTs) with active controls.

- We were not able to perform strength-of-evidence assessment.

Table 1. Inclusion and exclusion criteria

\begin{tabular}{|c|c|}
\hline PICOTS & Inclusion and Exclusion Criteria \\
\hline Population & $\begin{array}{l}\text { Include: Adults over } 18 \text { years enrolled in MAT program for OUD, people soon to be released } \\
\text { from incarceration (e.g., released to the community during the study) } \\
\text { Exclude: Special populations (e.g., people younger than } 18 \text { years of age, pregnant } \\
\text { people, palliative care/end-of-life, HIV, people incarcerated for the duration of the study) }\end{array}$ \\
\hline Intervention & $\begin{array}{l}\text { Include: Medication formulation (e.g., XR), psychosocial adjuncts (e.g., counseling, CBT, peer } \\
\text { support, 12-step programs, mindfulness therapy), CM, care settings/logistical support (e.g., MAT } \\
\text { setting, low-threshold models), financial support (e.g., MAT medication/program reimbursement), } \\
\text { and health IT }\end{array}$ \\
\hline Comparator & $\begin{array}{l}\text { Include: Comparator groups (e.g., TAU) must also consist of individuals with access to MAT, } \\
\text { including usual referral and enrollment in outpatient in-person treatment programs, daily MAT } \\
\text { formulations, XR formulations }\end{array}$ \\
\hline Outcomes & $\begin{array}{l}\text { Include* } \\
\text { Primary: } \\
\text { Treatment retention } \\
\text { Secondary: } \\
\text { Mortality } \\
\text { Harms }\end{array}$ \\
\hline Timing & Include: Retention in MAT was evaluated for at least 3 months. \\
\hline Setting & $\begin{array}{l}\text { Include: Only studies conducted in countries ranked as Very High Human Development by the } \\
\text { United Nations' Development Programme's } 2018 \text { Statistical Update "Human Development Indices } \\
\text { and Indicators." Outpatient MAT only. }\end{array}$ \\
\hline $\begin{array}{l}\text { Study } \\
\text { design }\end{array}$ & $\begin{array}{l}\text { Include: High-quality SRs, RCTs, observational studies (nonrandomized studies with } \\
\text { control groups) }\end{array}$ \\
\hline Language & Include: English \\
\hline
\end{tabular}

$\mathrm{CBT=cognitive} \mathrm{behavioral} \mathrm{therapy;} \mathrm{CM}=$ contingency management; HIV=human immunodeficiency virus; IT=information technology; MAT=medications for addiction treatment; OUD=opioid use disorder; PICOTS=population, intervention, comparator, outcomes, timing, setting; RCT=randomized controlled trial; SR=systematic review; TAU =treatment as usual; $\mathrm{XR}=$ extended-release

* Systematic reviews and primary studies were included only if they report the primary or secondary outcomes of interest.

We refined the scope of this rapid review in consultation with the partners and a topic expert. The protocol was developed based on input from experts and stakeholders and was registered in the PROSPERO database (CRD42019134739) ${ }^{53}$ and publicly posted on the AHRQ Effective Health Care Program website. ${ }^{54}$

While a rapid review cannot be fully exhaustive or comprehensive, we aimed to provide an overview of the literature pertaining to retention strategies for MAT to inform decision making during a national epidemic. 


\section{Search Strategies}

We searched OVID MEDLINE and the Cochrane Database of Systematic Reviews from February 12, 2009, to June 16, 2019, in consultation with a medical research librarian. We conducted an additional gap search through August 20, 2019. For health information technology (IT), we also searched the Google Play and Apple stores for commercial apps. See Appendix A for search strategies and full list of databases searched.

Because of the broad scope of retention strategy interventions, we consulted with our partners, topic experts, and published and unpublished literature ${ }^{16,44,55,56}$ to develop a classification scheme to aid in synthesis. We classified MAT retention interventions in the following manner:

- Care settings, services, and logistical support

- Contingency management (CM),

- Health IT

- XR medication-based treatments

- Psychosocial support interventions

- Financial support

\section{Study Selection}

We included studies that directly compared MAT retention strategies with each other or treatment as usual (TAU) if TAU included use of and potential access to MAT. We excluded studies that tested interventions that did not use MAT or used controls that did not have access to MAT (i.e., no treatment, placebo, abstinence-only, or nonpharmacologic programs). We also excluded studies of medications that are not currently FDA approved. We defined retention as continued treatment or medication engagement for at least 3 months. In the absence of established definitions of treatment retention for MAT, we considered 3 months as the minimum clinically relevant time interval to assess retention. We were purposefully inclusive of a wide range of study definitions of retention (e.g., retention defined by self-report, medication prescribing, or visits to clinics to receive supportive treatment). In many cases, retention was not clearly defined, and we could not determine the degree to which patients were adherent to MAT, to adjunct services, or abstained from illicit substances. Participants were still considered retained in MAT if they continued to use illicit opioids or missed MAT appointments/medication dosages. We did not equate study retention with treatment retention.

When possible, we focused on SRs and on RCTs published subsequent to SRs. Systematic reviews were included if they addressed MAT retention, searched at least two databases, performed quality assessment of individual studies, and were current (within 10 years of the date of the search). If the SR identified relevant studies but did not provide a synthesis specific to retention, we used the SR to identify RCTs. In cases where there were no/few identified RCTs, we included observational studies.

\section{Quality Appraisal}

SRs were considered good quality and were included if they met four basic criteria: searched more than two databases, performed quality assessment, used predetermined inclusion/exclusion criteria, and described the search strategy used. To balance efficiency, rigor, and inclusivity, we focused on these four critical features common to quality assessment tools for SRs. For RCTs and observational studies, we conducted dual independent review of study quality using criteria developed by the U.S. Preventive Services Task Force. ${ }^{57}$ We did not downgrade studies with 
high attrition in our quality ratings, because it was related to our primary outcome. We did not exclude studies on the basis of study quality; rather, we used study quality to guide our interpretation of results and identify areas for improvement in future research.

To assess the strength of a body of evidence, we relied on published SRs when we could, which meant that assessment tools could differ across intervention sections (e.g., in sections that had SRs as well as individual studies, the SR may have used a different tool from the one we used for individual studies). Also, given the rapid nature of this review, we did not conduct quantitative analyses, which are commonly used to assess precision in formal strength of evidence assessments.

\section{Data Collection and Synthesis}

A team member abstracted details related to study design, setting, population, intervention and followup, outcomes, and harms. We reported retention outcomes for each included study, using intention-to-treat (ITT) analysis; if studies did not report ITT, we calculated this if data were available. We then assessed overall effectiveness for each intervention with a particular focus on the degree to which the literature reflects real-world clinical circumstances. Through iterative discussions with topic experts and SR experts, the study team discussed methodological weaknesses of the body of literature as well as individual studies and determined which studies provided the most reliable evidence. Qualitative synthesis placed emphasis on those studies deemed by the study team to be most reliable and of higher quality.

\section{Results}

Our search retrieved 1,580 unique titles and abstracts from which we reviewed 258 fulltext articles for eligibility and included 2 SRs and 39 unique primary studies. No included studies were identified in the gap search (Figure 2). MAT retention duration ranged from 3 to 24 months. See Appendix C for quality ratings of all included studies. 
Figure 2. Literature flow diagram

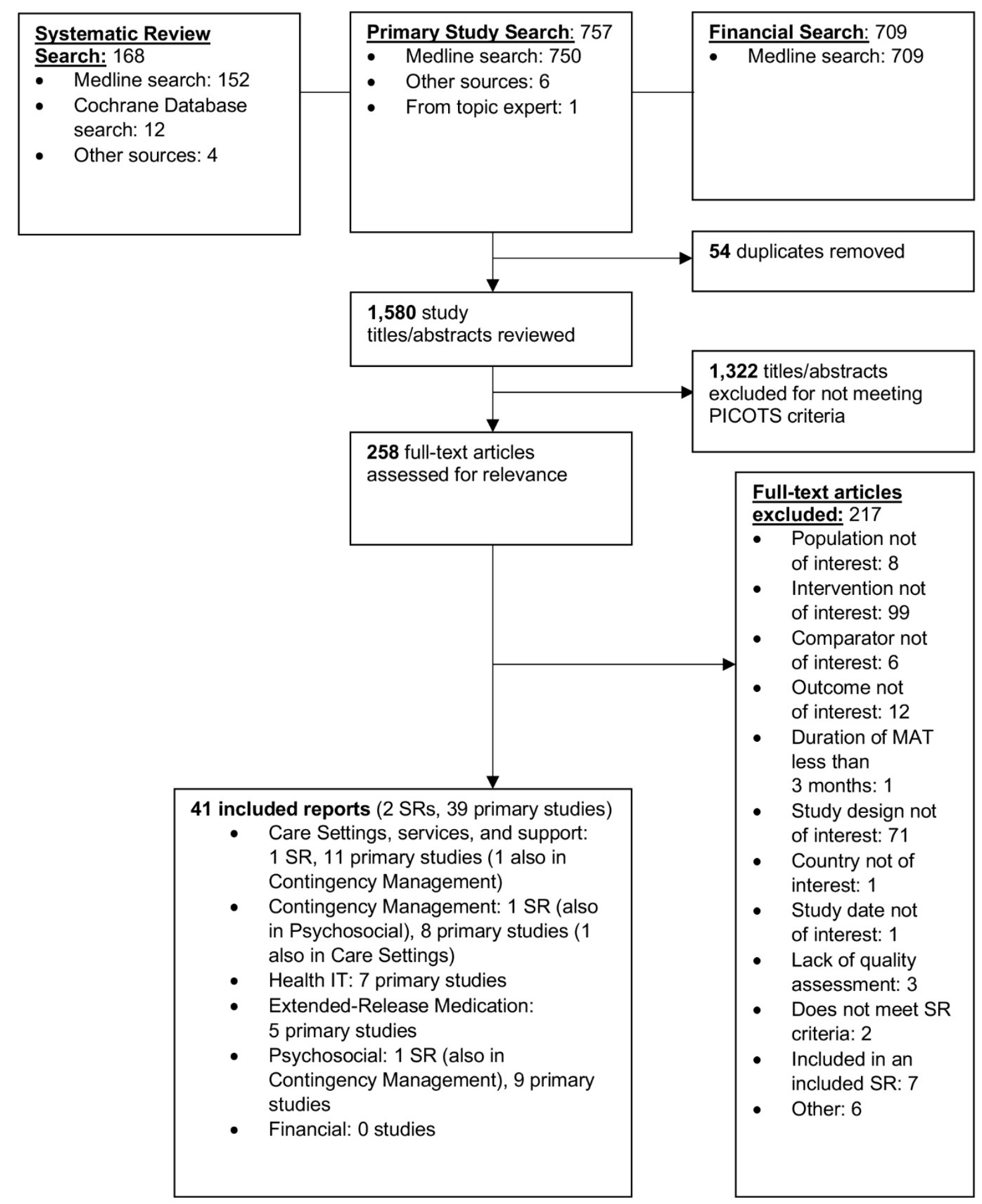




\section{Care Settings, Services, and Logistical Support}

We defined care settings and services as interventions that provide MAT in alternative settings or integrated models, compared with TAU conditions that offered MAT alone through specialty treatment programs. We defined logistical support as interventions that changed the process of MAT initiation and maintenance as compared with TAU, or interventions that provided MAT in conjunction with logistical supports, such as housing with health and social services assistance. We used an existing framework ${ }^{58}$ to further categorize care setting interventions into the following:

- Interventions that initiate MAT for soon-to-be-released incarcerated populations (1 SR of 21 studies, $^{1}$ and 2 additional $\mathrm{RCTs}^{2,3}$ )

- Integration of MAT with psychiatric or primary care services (PC) (three RCTs ${ }^{4-6}$ )

- Integration of MAT in emergency department (ED)/hospital settings (two RCTs ${ }^{7,8}$ )

We identified one good quality SR ${ }^{1}$ and 11 primary studies (one good quality; ${ }^{9}$ nine fair; ${ }^{3-8,10-12}$ and one poor $^{2}$ ) that investigated care setting/logistical support interventions. $^{2-7,9-12}$ Most were downgraded for unblinded outcome assessment or high rates of crossover.

\section{Key Question 1: Effectiveness and Comparative Effectiveness of MAT Retention Strategies}

Table 2 provides a summary of findings across care settings/logistical support, and Appendix B Table 1 and Appendix C Table 1 provide details for included studies.

Table 2. Summary of findings for care settings / services / logistical support

\begin{tabular}{|l|l|l|}
\hline \multicolumn{1}{|c|}{ Care Setting Intervention } & \multicolumn{1}{|c|}{$\begin{array}{c}\text { Studies, Quality } \\
\text { n }\end{array}$} & \multicolumn{1}{|c|}{ Results } \\
\hline $\begin{array}{l}\text { MAT for soon-to-be-released } \\
\text { incarcerated populations }\end{array}$ & $\begin{array}{l}\text { 1 SR of 21 } \text { studies }^{1} \\
2 \text { additional studies } \\
1 \text { poor quality) } \\
\mathrm{n}=228\end{array}$ & Higher retention \\
\hline $\begin{array}{l}\text { Psychiatric or PC service } \\
\text { integration }\end{array}$ & $\begin{array}{l}3 \text { studies }^{4-6} \text { (all fair quality) } \\
\mathrm{n}=631\end{array}$ & $\begin{array}{l}\text { Inconsistent (2 studies, benefit in one and } \\
\text { no difference from traditional setting in other; } \\
1 \text { study in PC, no difference from traditional } \\
\text { setting) }\end{array}$ \\
\hline ED / hospital setting & $\begin{array}{l}2 \text { studies } \\
\mathrm{n}=429\end{array}$ & $\begin{array}{l}\text { ED no worse than traditional setting (1 higher } \\
\text { retention, 1 no difference) }\end{array}$ \\
\hline Logistical support & $\begin{array}{l}\text { quality) } \\
\mathrm{n}=718\end{array}$ & No difference \\
\hline
\end{tabular}

ED=emergency department; MAT=medications for addiction treatment; PC=primary care; SR=systematic review

\section{Care Setting: MAT for Soon-To-Be-Released Incarcerated Populations}

A good quality $\mathrm{SR}^{1}$ of 21 studies (6 RCTs and 15 observational) and 2 additional RCTs ${ }^{2,3}$ examined interventions that initiate MAT in soon-to-be-released incarcerated OUD patients. The SR found that initiating MAT in this population was associated with high levels of postrelease treatment entry and retention compared with TAU controls who did not initiate MAT prior to release (retention rates 50\% [range 27-75\%] vs. 5\% [range 0-9\%]). ${ }^{1}$ The review assessed quality 
using Cochrane guidelines, with the majority of studies of fair quality (nine), followed by good and inadequate (six each). Two additional RCTs conducted in the United States (one poor ${ }^{2}$ and one fair quality ${ }^{3}$ ) similarly reported improved retention with initiation of MAT in soon-to-be-released incarcerated populations. One was a small 6-month study $(n=15)$ that randomized inmates to be offered the first monthly dose of XR injectable naltrexone prior to being released from prison compared with TAU and found that the intervention group had higher retention by multiple measures (mean number of injections received 2.8 (standard deviation $(\mathrm{SD})=1.9)$ vs. $1.3(\mathrm{SD}=1.9 ; 22 \%(2 / 9)$ ) received all 6 monthly injections vs. $0 \%(0 / 6)$; and 46\% vs. $22 \%$ treatment appointments attended, p-values not reported (NR)). ${ }^{2}$ The second study was a $2 \times 2$ factorial design $(n=213)$ that assessed the effect of prerelease buprenorphine treatment compared with an office-based buprenorphine or traditional outpatient treatment program and found that the prerelease buprenorphine group had higher mean number of days retained in treatment at 12 months (65.9 days (standard error (SE) 12.2) vs. 21.8 (SE 7.6), $\mathrm{p}=0.005$ ). ${ }^{3}$ Together, these studies suggest that initiating MAT prior to release from incarceration improves retention.

\section{Care Setting: Integration of MAT With Psychiatric and Primary Care Services}

Three fair-quality RCTs provide conflicting evidence on the effectiveness of integrating psychiatric or PC interventions on MAT retention. ${ }^{4-6}$ All were small studies (n range = 94-316): two of three involved integrating psychiatric care with substance use treatment (one methadone and one buprenorphine) and were conducted in the United States, and one was a study from France that integrated methadone treatment with PC. The largest study is a U.S. study offering psychiatric services on site at a traditional methadone treatment program compared with separate nonintegrated psychiatric and substance use care. While initiation and total days of psychiatric care were improved for onsite integrated services, there was no statistically significant difference in MAT retention at 12 months ( $\mathrm{n}=316,41 \%$ vs. $41 \%, \mathrm{p}=0.96){ }^{4}$

The second study integrating psychiatric care $(n=94)$ was a fair-quality three-arm U.S. trial that offered buprenorphine treatment in psychiatric clinics, a manually matrixed psychosocial model with cognitive behavioral therapy (CBT) in private clinics, and a specialized opioid treatment program. This study reported a significant association between treatment site and retention at 20 weeks ( $\mathrm{p}=0.05$ ), with 33.3 percent retained in the psychiatric setting, 51.5 percent retained in the psychosocial model, and 21.4 percent retained in the specialized outpatient treatment (retention). ${ }^{6}$ The one study in which treatment was integrated into PC was a noninferiority trial conducted across 10 sites in France $(n=195)$ that compared methadone treatment integrated with PC with specialized outpatient methadone treatment programs and found no statistically significant differences at 12 months (88\% retention in PC vs. 69\% in urgent care, $\mathrm{p}=0.13)^{5}$

\section{Care Setting: MAT in ED/Hospital Settings}

We identified two RCTs of fair quality that examined retention after introducing MAT in ED or hospital settings. ${ }^{7,8}$ One study enrolled patients at a U.S. safety-net hospital $(n=139)$ to initiation of buprenorphine with linkage to outpatient treatment within 7 days of discharge compared with TAU (medically supervised withdrawal and community referral to treatment). Patients in the hospital-initiated group reported a 2.4 times higher rate of buprenorphine or 
methadone use over 6 months (incidence rate ratio (IRR), 2.44, 95\% confidence interval [CI], 1.99 to 3.36). At 6-month followup, 12 (16.7\%) patients randomized to linkage compared with two $(3.0 \%)$ to TAU had continued on MAT $(\mathrm{p}=0.007) .{ }^{7}$ The second study was a followup study conducted in the United States of a 3-arm RCT $(n=290)$ of adults with OUD randomized to either 1) ED-initiated buprenorphine with linkage to PC within 72 hours, 2) referral to treatment (TAU), or 3) brief intervention in ED, and assessed retention at 6 and 12 months, defined by self-reported engagement in formal addiction treatment, and found no differences in retention at $6(53 \%$ vs. $60 \%$ vs. $51 \%$, p=0.546) or 12 months ( $49 \%$ vs. $49 \%$ vs. $63 \%$, p $=0.136){ }^{8}$

\section{Logistical Support}

As a whole, studies of logistical interventions enrolled patients with higher addiction severity and did not show improved MAT retention compared with a standard treatment setting. We identified one good- and three fair-quality RCTs (total $n=709$ ) that tested changes in MAT prescribing procedures, such as lessened MAT participation requirements ("low-threshold") or expedited initiation onto MAT treatment ("Script in a Day"), or the provision of housing with social/medical supports, compared with TAU. ${ }^{9-12}$ A U.S. trial of a low-threshold, patient-centered methadone intervention (optional counseling, modified clinic rules, no discharge for administrative violations) compared with TAU found no differences in retention at 12 months ( $n=300,48.6 \%$ vs. $46.3 \%, p=N R$ ). ${ }^{9}$ Similarly, another trial that involved low-threshold initiation intervention that only required once monthly counseling found no statistically significant differences in retention at $90(\mathrm{n}=212,35 \%$ vs. 31\%, $\mathrm{p}=$ not significant (NS)) and 180 days (37\% vs. 29\%, p=NS). ${ }^{11}$ An innovative intervention offering immediate access to methadone from a U.K. syringe exchange followed by transfer to office-based methadone compared with TAU similarly found no differences in retention at 3 months ( $n=100,51 \%$ vs. $47 \%$, $p=N R$ ). Finally, a trial of a Housing First intervention in which participants in Canada experiencing homelessness were assigned to one of three housing with health/social services groups compared with TAU (referral to housing assistance programs and outpatient specialty treatment), assessed retention using medication possession ratio (MPR) over 2 years and found no differences between groups ( $\mathrm{n}=97$, MPR 0.52 vs. 0.57, $\mathrm{p}=0.60) .{ }^{12}$ (See Appendix B Table 1.)

\section{Key Question 2: Harms of MAT Retention Strategies}

Most studies of MAT retention strategies did not evaluate possible harms. Only 4 of the 10 trials of care settings/services/logistical support reported serious harms or adverse events-of these, two did not specify in which arm the events occurred. A trial of a patient-centered methadone intervention reported 67 non-study-related hospitalizations and two non-study-related deaths, one from methadone overdose, out of 149 intervention participants. This compares with 59 hospitalizations, 4 non-study-related deaths, and 2 overdoses out of 151 TAU participants. ${ }^{9}$ In the study of prerelease MAT with XR-naltrexone, six patients in the prerelease MAT arm reported adverse events (two serious, not specified) compared with two (none serious) in the control arm. ${ }^{2}$

\section{Key Question 3: Participant Characteristics Associated With MAT Retention}

The majority of studies did not examine particular population characteristics to explain variation in responses to care settings/services/logistical support. As noted above, patients with OUD in criminal justice populations may benefit from prerelease initiation of MAT. The study 
of the prerelease MAT with office-based buprenorphine in a PC setting found no gender differences in retention outcomes. ${ }^{3}$

\section{Contingency Management}

Table 3 provides a summary of findings across CM interventions, and Appendix B Table 2 and Appendix C Table 2 provide details for included studies.

Table 3. Summary of findings for contingency management

\begin{tabular}{|c|c|c|}
\hline MAT Medication Type & $\begin{array}{c}\text { Studies, Quality } \\
\text { n }\end{array}$ & Results \\
\hline $\begin{array}{l}\text { Opioid receptor } \\
\text { antagonist MAT }\end{array}$ & $\begin{array}{l}2 \text { RCTs, injectable naltrexone (fair quality) })^{13,14} \\
n=73 \\
1 \text { RCT, naltrexone (fair quality) }{ }^{15} \\
n=67\end{array}$ & Higher retention \\
\hline $\begin{array}{l}\text { Opioid receptor } \\
\text { agonist/partial agonist } \\
\text { MAT }\end{array}$ & $\begin{array}{l}1 \text { SR, } 14 \text { CM studies with methadone, buprenorphine, or LAAM }{ }^{16} \\
n=1616 \\
3 \text { RCTs, methadone ( } 1 \text { good, } 2 \text { fair quality) }{ }^{11,17,18} \\
n=562 \\
1 \text { RCT, methadone or buprenorphine (fair quality) } \\
n=136\end{array}$ & No difference \\
\hline
\end{tabular}

CM=contingency management; LAAM=levo-alpha acetyl methadol; MAT=medications for addiction treatment; $\mathrm{RCT}=$ randomized controlled trial; $\mathrm{SR}=$ systematic review

Contingency management interventions involve providing a reward contingent upon the achievement of specified criteria. While CM is sometimes used in conjunction with other psychosocial interventions, we analyzed it separately, similar to the approach used in a prior SR on psychosocial interventions ${ }^{16}$.

One good-quality SR, ${ }^{16}$ and seven RCTs (one with a followup study) ${ }^{11,13-15,17-19}$ of CM interventions assessed retention outcomes among nonpregnant adults who received MAT for OUD. ${ }^{59}$ Contingency management improved retention on antagonist MAT, but not for opioid agonist MAT (Table 3). Appendix B Table 2 provides study details. Sample sizes per study for the seven identified RCTs ranged from 35 to 252 participants and we rated one study as good quality, ${ }^{18}$ and seven fair quality. ${ }^{11,13-15,17,19,59}$ Most were downgraded due to lack of evidence of allocation concealment, lack of similarity of groups at baseline, and lack of blinding.

\section{Key Question 1: Effectiveness and Comparative Effectiveness of MAT Retention Strategies}

A 2011 SR of 35 studies ( $n=4319$ ) that included heterogeneous CM interventions that rewarded opioid abstinence in individuals receiving agonist/partial agonist MAT (methadone, buprenorphine, or levo-alpha acetyl methadol [LAAM]) found no statistically significant difference in retention compared with agonist/partial agonist therapy (methadone, buprenorphine, or LAAM) alone (14 trials, $n=1616$, risk ratio (RR) $1.02[0.96,1.08]) .{ }^{16}$ The evidence included in the SR was assessed with Grading of Recommendations Assessment, Development and Evaluation (GRADE) as being high strength of evidence.

Four of the seven additional trials (of fair to good quality) that we identified also used agonist/partial agonist MAT (methadone or buprenorphine) and confirmed findings of the 
SR. ${ }^{11,17-19}$ The remainder, three fair-quality studies, reported improved retention in MAT. ${ }^{13-15}$ These three studies were conducted at the same site, but with separate populations. They used antagonist therapy (naltrexone), had similar criteria for accessing the reward (participants were required to take naltrexone that was provided free of charge and in close proximity to access to the reward), and provided a similar type of reward (access to a therapeutic workplace where participants earned vouchers to exchange for preferred goods and services). The studies differed in the type of naltrexone formulation administered (two using monthly XR-naltrexone and one using daily naltrexone). Regardless of formulation, retention outcomes were greater in contingency participants compared with participants who were permitted access to the workplace without contingency: injectable, XR-naltrexone (two studies, $n=35,66 \%$ vs. $35 \%$ received all scheduled injections, $\mathrm{p}=0.026^{13} ; \mathrm{n}=38,74 \%$ vs. $26 \%$ received all scheduled injections, $\mathrm{p}=0.004) ;{ }^{14}$ and daily naltrexone ( $\mathrm{n}=67,54 \%$ vs. $16 \%$ retention at end of study, $\left.\mathrm{p}<0.01\right) .{ }^{15} \mathrm{In}$ an additional followup study, the group differences in retention were no longer observed 6 months after the intervention ended $(n=67, p=0.66) .{ }^{59}$

\section{Key Question 2: Harms of MAT Retention Strategies}

The $\mathrm{SR}^{16}$ sought data on adverse events but did not report any, and only one of the eight RCTs reported harms. The 1 RCT that reported harms used daily naltrexone and reported adverse events in 8 out of 67 participants, 6 of whom were in the contingency group. ${ }^{15}$ The adverse events included one lethal opioid overdose in a contingency group participant that occurred a month after study conclusion. Other adverse events included sexual dysfunction, abdominal problems, headache, sleep problems, opioid withdrawal, nausea, chills, rapid heart rate, and shakiness.

\section{Key Question 3: Participant Characteristics Associated With MAT Retention}

The identified studies did not assess differential effectiveness of CM on retention by defined participant characteristics (e.g., gender/sex, socioeconomic status, etc.).

\section{Health Information Technology}

We adopted the Office of the National Coordinator for Health IT Playbook definition and categorization of health IT that defines the scope of IT to include electronic medical record interventions such as prescription drug monitoring, phone apps, e-prescribing, telehealth/teleconsult, and computerized decision aids. ${ }^{56}$ Figure 3 presents an overarching framework, adapted from the Health IT Playbook, for the ways in which health IT interventions are proposed to increase retention in MAT.

Seven unique completed studies (three fair-quality RCTs, one poor-quality RCT, and three fair-quality cohort studies), ${ }^{20-26,60}$ met the inclusion criteria for health IT interventions, including an active control involving in-person MAT as a comparator, and MAT retention as an outcome. Table 4 provides a summary of findings across health IT interventions and Appendix B Table 3 provides details for included studies. 
Figure 3. Spectrum of IT interventions proposed to increase MAT retention

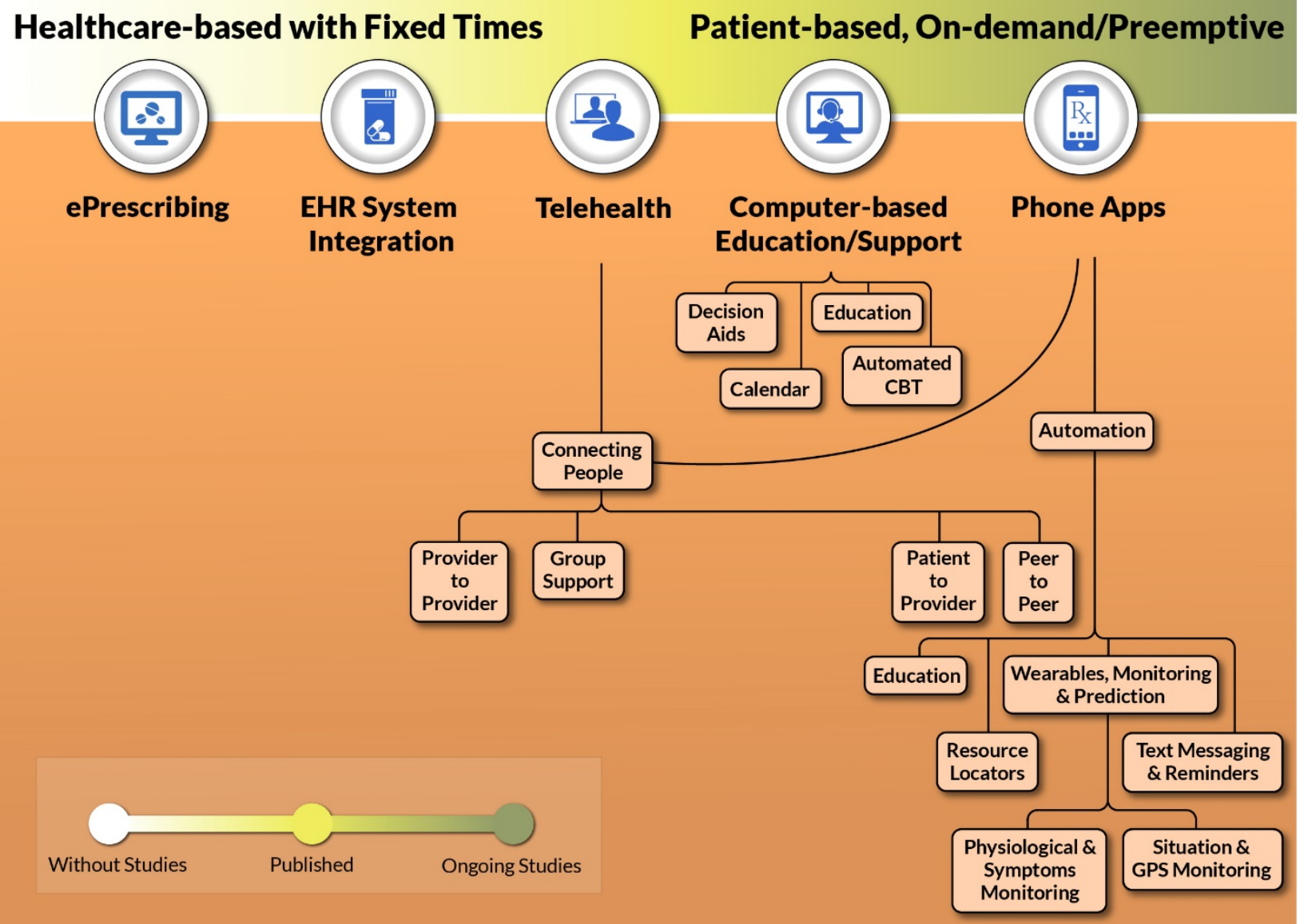

Apps=applications; $\mathrm{CBT}=$ cognitive behavioral therapy; EHR=electronic health record; GPS=global positioning system This figure adapted from the Office of the National Coordinator for Health IT Playbook definition and categorization of health IT. ${ }^{56}$

Table 4. Summary of findings for health IT

\begin{tabular}{|c|c|c|}
\hline Intervention & $\begin{array}{l}\text { Studies, Quality } \\
\text { n }\end{array}$ & Results \\
\hline Telehealth & $\begin{array}{l}0 \text { RCTs; } 3 \text { fair-quality cohort } \\
\text { studies }^{20-22} \\
n=3965\end{array}$ & $\begin{array}{l}\text { Telehealth no worse than in-person (higher } \\
\text { retention in largest study and no difference in } \\
\text { two smaller) }\end{array}$ \\
\hline $\begin{array}{l}\text { Computer-based education } \\
\text { and/or support }\end{array}$ & $\begin{array}{l}2 \text { fair- } 23,24 \text { and } 1 \text { poor-quality } \\
\mathrm{RCT}^{25} \\
\mathrm{n}=262\end{array}$ & No difference \\
\hline $\begin{array}{l}\text { Multicomponent mobile and } \\
\text { computer-based program }\end{array}$ & $\begin{array}{l}1 \text { fair-quality } \mathrm{RCT}^{26} \\
\mathrm{n}=1426\end{array}$ & No difference \\
\hline Phone apps & None & 6 commercially available apps identified \\
\hline
\end{tabular}

IT= information technology; RCT= randomized controlled trial

Key Question 1: Effectiveness and Comparative Effectiveness of MAT Retention Strategies 
Four RCTs (three fair quality ${ }^{24-26}$ and one poor $^{23}$ ) and three fair-quality retrospective cohort studies $^{20-22}$ assessed IT interventions for MAT retention. No RCT found IT intervention to be less effective than in-person approaches.

The largest RCT (five times the size of the others combined) of fair quality ( $n=1426)$ is an industry-sponsored study where patients new to buprenorphine treatment were randomized to receive in-person buprenorphine MAT (TAU) or buprenorphine MAT plus a Here-To-Help (HTH) IT intervention consisting of calls from care coaches and access to online educational materials, treatment calendars, and self-reported information from previous participants. ${ }^{26,60}$ At 12 months, ITT analysis indicated no significant difference between groups (55.0\% HTH vs. 56.1\% TAU, p-value=NR). Planned post-hoc analysis revealed that people who completed a greater number of intervention calls with coaches had a greater probability of retention in MAT (adjusted logistic regression $\operatorname{Exp}(\beta)=1.01, \mathrm{p}<0.001$ ) and 64 percent of participants in the HTH program who completed at least three HTH sessions remained in buprenorphine MAT compared with 56 percent in TAU $(\mathrm{p}<0.025){ }^{26}$

Health IT is relatively new to healthcare and not part of the provision of MAT in the United States, so it is not known, if offered, the degree to which people would use it. While OUD treatment differs widely from the United States, a large retrospective Canadian study ( $\mathrm{n}=3733$ ) suggests that up to half of patients might choose health IT as part of their treatment if offered, without worsened retention. ${ }^{20}$

\section{Key Question 2: Harms of MAT Retention Strategies}

As a whole, harms were not well reported across health IT studies, with the majority not mentioning whether they assessed potential harms. One RCT reported that 12 adverse events occurred in a study of 82 participants (15\% overall; $17 \%$ in intervention group and $12 \%$ in TAU), but no details were provided about the nature of the events. ${ }^{23}$

A small feasibility study that did not report on retention and therefore was not included in our review provides helpful detail on some challenges and harms that may be unique to IT. ${ }^{61}$ These issues included difficulties with computers or internet problems, lack of study staff training in technical support with patient connectivity, difficulties with compatibility with organizational security systems, patient privacy, and loss of clinical care time due to IT issues.

\section{Key Question 3: Participant Characteristics Associated With MAT Retention}

There is inconclusive information to determine which patients are most likely to benefit from IT and which types of IT might be most appropriate for specific patients (e.g., patient-provider communication, treatment, and/or counseling, educational support, reminders, monitoring). The large retrospective cohort study from Ontario, Canada, found a significant association between sex, clinic region (northern vs. southern), age, and peak methadone dose but not for clinic rurality. ${ }^{20}$ Patients who chose treatment delivery via predominantly telemedicine (greater than $75 \%$ of appointments) came from both urban (77\%) and rural (23\%) populations. Findings from a secondary analysis of an RCT that replaced the second half-hour of every in-person counseling session with an IT Therapeutic Educational System found that including a Therapeutic Educational System as part of care was better for patients who were employed, highly anxious,

ambivalent about opioid abstinence, and had crack cocaine use in the past 30 days. $^{62}$ 


\section{Commercially Available Mobile Apps}

Six apps were identified via the Google Play and Apple store (Opioid Addiction Recovery Support, Pear Re-SETO, Thrivee, A-CHESS, COR-12, FlexDek: MATList). There were no published studies about these apps with regard to OUD treatment. All apps have some educational component. Five of six apps contain some feature that allow patients to connect with peers, either through interaction in forums, virtual group therapy, or direct contact, and allow users to track their progress through treatment. At least two apps (A-CHESS and FlexDek MAT) provide patients with resources to identify local Narcotics Anonymous meetings, either through direct Global Positioning System (GPS) locating or by acting as a repository for schedules. We only identified evidence for the A-CHESS app, which was initially developed for alcohol use disorder, but an ongoing RCT is evaluating A-CHESS for OUD.

\section{Extended-Release Medication-Based Treatment for OUD}

Extended-release is a long-acting form of MAT delivered as either injectable or implant-based formulations. The only three XR formulations currently approved by the U.S. FDA for the treatment of OUD are a 1-month buprenorphine injection, a 6-month buprenorphine implant, and a 1-month naltrexone injection.

We identified a total of five fair-to-good-quality RCTs ${ }^{27-31}$ comparing XR formulations (naltrexone injection, buprenorphine injection, and buprenorphine implant) head-to-head against daily MAT formulations (naltrexone, buprenorphine/naloxone, and buprenorphine). Most were downgraded for unblinded treatment or outcome assessment.

Table 5a provides a summary of treatment retention findings for XR and daily formulations for the same drug, while Table $5 \mathrm{~b}$ summarizes retention findings for XR and daily formulations for drugs across different agonist/antagonist categories and formulations (see Appendix B Table 4 and Appendix C Table 4 for details).

Table 5a. Summary for extended-release versus daily MAT formulations within the same agonist/antagonist drug categories

\begin{tabular}{|c|c|c|c|}
\hline Comparison & Studies & Results for Extended-Release & Study Setting \\
\hline $\begin{array}{l}\text { Naltrexone } \\
\text { Extended-Release 1-Month } \\
\text { Injection vs. } \\
\text { Daily Naltrexone }\end{array}$ & $\begin{array}{l}1 \text { study }^{27} \\
\text { fair quality } \\
n=60\end{array}$ & $\begin{array}{l}\text { Higher retention } \\
(57.1 \% \text { vs. } 28.1 \% \text {, hazard } \\
\text { ratio=2.18, } 95 \% \mathrm{Cl}=1.07,4.43 \text {, at } \\
6 \text { months of treatment) }\end{array}$ & $\begin{array}{l}\text { Inpatient followed by } \\
\text { outpatient specialty } \\
\text { treatment center } \\
\text { medicine setting }\end{array}$ \\
\hline $\begin{array}{l}\text { Buprenorphine } \\
\text { Extended-Release 1-Month } \\
\text { Injection vs. Daily SL- } \\
\text { Buprenorphine/Naloxone }\end{array}$ & $\begin{array}{l}1 \text { study }^{28} \\
\text { fair quality } \\
n=428\end{array}$ & $\begin{array}{l}\text { Similar retention } \\
\text { ( } 56.8 \% \text { vs. } 58.1 \%, p \text {-value NR, at } \\
24 \text { weeks) }\end{array}$ & $\begin{array}{l}\text { Outpatient specialty } \\
\text { treatment center }\end{array}$ \\
\hline $\begin{array}{l}\text { Buprenorphine } \\
\text { Extended-Release 6-Month } \\
\text { Implant vs. Daily } \\
\text { SL-Buprenorphine }\end{array}$ & $\begin{array}{l}1 \text { study }^{29} \\
\text { good quality } \\
\mathrm{n}=177\end{array}$ & $\begin{array}{l}\text { Similar retention } \\
\text { (93.1\% vs. 93.3\%, p-value NR, at } \\
6 \text { months) }\end{array}$ & $\begin{array}{l}\text { Outpatient specialty } \\
\text { treatment center }\end{array}$ \\
\hline
\end{tabular}

$\mathrm{CI}=$ confidence interval; MAT=medications for addiction treatment; $\mathrm{NR}=$ not reported; $\mathrm{SL}=$ sublingual 
Table 5b. Summary for extended-release versus daily MAT formulations across different agonist/antagonist categories

\begin{tabular}{|c|c|c|c|}
\hline Comparison & Studies & Results for Extended-Release & Study Setting \\
\hline $\begin{array}{l}\text { Naltrexone } \\
\text { Extended-Release 1-month } \\
\text { Injection vs. Daily SL- } \\
\text { Buprenorphine/Naloxone }\end{array}$ & $\begin{array}{l}2 \text { studies }^{30,31} \text {, } \\
1 \text { fair, } 1 \text { good } \\
\text { quality } \\
n=729 \\
(570,159)\end{array}$ & $\begin{array}{l}\text { Inconclusive } \\
\text { ( } n=570,33.9 \% \text { vs. } 40.0 \%, \\
\text { p-value NR, at } 24 \text { weeks) } \\
\text { (n=159, mean (SD) time } 69.3 \\
\text { (25.9) vs. } 63.7(29.9) \text { days, } \\
\text { p-value NR, at 3-months) }\end{array}$ & $\begin{array}{l}\text { Inpatient followed by } \\
\text { outpatient specialty } \\
\text { treatment center medicine } \\
\text { setting (larger study); } \\
\text { Outpatient specialty } \\
\text { treatment center } \\
\text { (small study) }\end{array}$ \\
\hline
\end{tabular}

MAT=medications for addiction treatment; $\mathrm{NR}=$ not reported; $\mathrm{SL}=$ sublingual

\section{Key Question 1: Effectiveness and Comparative Effectiveness of MAT Retention Strategies}

One fair-quality study $(n=60)^{27}$ compared XR-naltrexone monthly injection with daily naltrexone. Retention was defined as documented clinical contact at 6 months and favored the XR-naltrexone group (57.1\% vs. 28.1\%, hazard ratio $(\mathrm{HR})=2.18,95 \% \mathrm{CI}=1.07,4.43)$.

Two studies compared XR and daily buprenorphine formulations, though neither assessed retention as a primary outcome. ${ }^{28,29}$ One was a good-quality multisite trial $(n=177)$ that randomized participants who were stable on a low dose of daily buprenorphine prior to enrollment to a buprenorphine 6-month implant versus daily sublingual (SL)-buprenorphine and found no difference in rates of treatment retention at 6 months (93.1\% vs. 94.3\%, p-value NR). ${ }^{29}$ The other was a larger fair-quality trial $(n=428)$ of a weekly, followed by monthly, buprenorphine injection compared with daily SL-buprenorphine/naloxone that enrolled treatment-seeking participants and found no difference in retention at 24 weeks $(56.8 \% \mathrm{vs}$. $58.1 \%$, p-value NR). ${ }^{28}$

Two studies comparing XR-naltrexone injection versus daily SL-buprenorphine/naloxone had inconsistent results. ${ }^{30,31}$ One was a good-quality study conducted in Norway $(n=159)$ that recruited patients from outpatient and inpatient settings. ${ }^{31}$ Treatment retention was defined as mean days until dropout from the study medication and did not differ between the two groups (mean (SD) days 69.3 (25.9) XR-naltrexone vs. 63.7 (29.9) days SL-buprenorphine/naloxone, p-value NR) The other was a fair-quality U.S. study that recruited 570 patients from community outpatient treatment programs. ${ }^{30}$ Retention was defined as percentage of patients receiving MAT at 3 months and was lower with XR-naltrexone compared with SL-buprenorphine/naloxone using ITT analysis (33.9\% vs. 40.0\%, p-value NR).

Our synthesis identified study design issues that may have impacted the retention results, particularly for XR-naltrexone formulations. The study that found that XR-naltrexone injection improved retention compared with SL-buprenorphine/naloxone randomized only those participants who successfully completed medically supervised opioid withdrawal. In contrast, the other study that found lower retention with XR-naltrexone randomized patients prior to their completion of supervised withdrawal and had high rates of treatment induction failure (72\% vs. $94 \%, \mathrm{p}<.0001$ ) in the XR-naltrexone compared with the SL-buprenorphine/naloxone group; this could explain the lower retention rates reported. Restrictive study inclusion criteria that exclude participants with alcohol dependence or polysubstance use $\mathrm{e}^{28,31}$ are also likely to affect generalizability of the results.

\section{Key Question 2: Harms of MAT Retention Strategies}


Studies of XR formulations reported a variety of adverse events, ranging from serious fatal and nonfatal adverse events to adverse events presumed secondary to treatment medication. All studies reported nonserious adverse events at XR-naltrexone and XR-buprenorphine injection sites.

Sullivan et al. $2019(\mathrm{n}=60)$ reported one severe adverse drug-related event when one of 28 participants developed hives after receiving XR-naltrexone injection and was removed from the study. ${ }^{27}$ Lee et al. $2018(\mathrm{n}=570)$ reported a total of 28 overdose events among 23 participants. ${ }^{30}$ While these overdose events were not categorized as drug related, 18 (64\%) of the 28 events were among participants randomized to XR-naltrexone, and included eight participants who had failed treatment induction and never received an injection. Five overdose events were fatal and included two participants in the XR-naltrexone arm and three in the SL-buprenorphine/naloxone arm.

\section{Key Question 3: Participant Characteristics Associated With MAT Retention}

There is limited information to determine which patients are most likely to benefit from XR formulations. None of the studies we reviewed noted differences in participant characteristics that predicted retention for XR formulations.

\section{Psychosocial Support}

We used a prior review ${ }^{16}$ to define psychosocial support interventions, which include psychiatric care, psychotherapy, counseling, and social work services that provide psychological support ranging from structured psychotherapies such as CBT and supportive expressive therapy to behavioral interventions. We analyzed CM interventions separately above.

One good-quality SR ${ }^{16}$ and nine additional RCTs ${ }^{32-40}$ (sample size range=49-653) examining psychosocial supports for MAT met inclusion criteria; an additional two studies included IT interventions and are reviewed in that section. ${ }^{24,26}$ We rated two studies as good quality ${ }^{39,40}$; four as fair ${ }^{35-38}$, and three as poor. ${ }^{32-34}$

Most were downgraded due to unblinded outcome assessment. Table 6 provides a summary of findings and Appendix B Table 5 provides study details. Quality ratings for individual studies are reported in Appendix C Table 5.

Table 6. Summary of findings for psychosocial interventions

\begin{tabular}{|c|l|l|}
\hline Psychosocial Intervention & \multicolumn{1}{|c|}{$\begin{array}{c}\text { Studies, Quality } \\
\mathbf{n}\end{array}$} & \multicolumn{1}{c|}{ Results } \\
\hline $\begin{array}{l}\text { Psychosocial interventions: } \\
\text { behavioral (e.g., CBT) } \\
\text { psychoanalytic } \\
\begin{array}{l}\text { (e.g., short-term } \\
\text { interpersonal therapy) } \\
\text { counseling }\end{array}\end{array}$ & $\begin{array}{l}\text { 1 SR of 27 studies, } \mathrm{n}=3124^{16} \text { (SR } \\
\text { rated evidence as high quality } \\
\text { using GRADE) }\end{array}$ & $\begin{array}{l}\text { No difference in retention between } \\
\text { psychosocial intervention and } \\
\text { control groups (SR and RCTs) in all } \\
\text { but one poor quality study }\end{array}$ \\
$\begin{array}{l}\text { (e.g., intensive } \\
\text { outpatient counseling) } \\
\text { other (e.g., 12-step } \\
\text { facilitation therapy) }\end{array}$ & $\begin{array}{l}\text { 9 RCTs, } \mathrm{n}=2483(3 \mathrm{fair}, 35-38 \\
\left.2 \text { good quality }{ }^{39,40}\right)\end{array}$ & $\begin{array}{l}\text { Many of the studies reviewed } \\
\text { included some form of counseling } \\
\text { in the control groups, which may } \\
\text { explain the lack of demonstrated } \\
\text { effectiveness. }\end{array}$ \\
\hline
\end{tabular}

$\mathrm{CBT}=$ cognitive behavioral therapy; GRADE=Grading of Recommendations Assessment, Development and Evaluation; $\mathrm{RCT}=$ randomized controlled trial; $\mathrm{SR}=$ systematic review 


\section{Key Question 1: Effectiveness and Comparative Effectiveness of MAT Retention Strategies}

An SR with meta-analysis found that adding structured psychosocial interventions to MAT did not improve retention compared with standard MAT (27 studies, $\mathrm{n}=3124, \mathrm{RR} 1.03$, 95\% CI 0.98 to 1.07$).{ }^{16}$ The SR assessed the strength of the body of evidence with GRADE and rated it as high quality. Of the nine additional RCTs, eight reported no statistically significant effect of psychosocial interventions. ${ }^{33-40}$ However, many of the studies reviewed included some form of counseling in the control groups, which may explain the lack of effect. One poor-quality study reported significantly higher buprenorphine MAT retention in the intervention group, which included a Community Reinforcement Approach (CRA) component that makes use of an individual's social networks to encourage adherence to the program compared with $\mathrm{CM}$ alone ( $\mathrm{n}=170,80 \%$ CRA vs. 64\% CM-alone; odds ratio (OR) 2.3, 95\%CI 1.15-4.60). ${ }^{32}$

\section{Key Question 2: Harms of MAT Retention Strategies}

The one study in which there was a statistically significant benefit of psychosocial intervention did not report any significant harms ${ }^{32}$ Another study $(\mathrm{n}=300)$ reported significant potential harm from psychosocial intervention. ${ }^{34}$ In this study, when controlling for number of days in treatment, more exposure to counseling was significantly associated with increased frequency of heroin use, cocaine use, and criminal activity (all $p<0.01$ ). The authors suspected that this association was due to confounding by indication as clinicians tended to insist on participation in additional services for patients who were not progressing. This same study also reported higher self-reported burden on participants and found the intervention group reported increased burden compared with the control $(\mathrm{p}<0.05)$. Looking across studies, we found differences in time commitment between intervention and control conditions in six studies that may have affected intervention fidelity, attrition rates, and retention outcomes due to increased treatment burden. ${ }^{32,34,37-40}$

Another study ( $\mathrm{n}=542)$ of pharmacist-delivered motivational interviewing versus normal practice for methadone patients found that self-reported physical health was statistically poorer for the intervention group; they theorized these results were due to increased awareness of health due to increased conversations between participant and pharmacist in the treatment group. ${ }^{33}$ Other studies reported adverse events and non-overdose-related deaths that the study authors judged to be unrelated to the interventions studied. ${ }^{35,38}$

\section{Key Question 3: Participant Characteristics Associated With MAT Retention}

Few included studies provided information about which patients, if any, are most likely to benefit from psychosocial interventions. A study $(n=125)$ of XR-naltrexone coupled with a Behavioral Naltrexone Therapy (BNT) intervention compared with XR-naltrexone coupled with Compliance Enhancement reported a significant interaction $(\mathrm{p}=0.03)$ between condition and severity of OUD. ${ }^{36}$ For low-severity patients (less than six bags of heroin per day), retention was highest in the BNT group (60\% at 6 months). BNT adapted elements of CRA in encouraging positive social reinforcement.

\section{Financial Support}

We defined financial support as individual and system-level interventions to lower financial barriers to MAT, ranging from financial subsidies to assist enrollment in MAT programs to 
expanding MAT coverage by Medicaid and private health plans. We did not identify any SRs or RCTs of financial interventions to improve retention in MAT; expanded searches of observational studies also did not yield relevant studies.

\section{Discussion}

Although MAT improves short- and long-term outcomes for people with OUD and reduces mortality, various reports estimate that fewer than half are retained in MAT treatment at followup. ${ }^{48}$ Overall, we found few studies evaluating interventions to improve retention in MAT and many did not assess retention longer than 3 months. Studies also varied in experimental design, measures of retention, and intervention types, making across-study comparisons difficult. The majority of the studies were downgraded in quality due to a lack of blinding of outcome assessors and high study attrition rates.

\section{Care Settings/Services/Logistical Support}

Our findings suggest that interventions that introduce MAT to soon-to-be-released incarcerated patients are an effective way to improve retention in this high-risk population. Given the high proportion of OUD in criminal justice populations and the exponential increase in overdose risk within the first few weeks of reentry into the community, ${ }^{63,64}$ interventions in this setting have potential to be high impact.

We also found that interventions integrating MAT into hospital and emergency settings prior to discharge were no worse for retention at 3 months than when MAT is delivered in traditional settings, though only two studies were included in our review suggesting additional studies may change conclusions.

Providing healthcare and social services alongside MAT makes intuitive sense to improve convenience and provide patient-centered care, and improve retention, particularly in areas where there are few specialty treatment programs. However, studies supporting MAT delivery in nontraditional settings were small, heterogeneous, or were conducted in non-U.S. settings that have different treatment regulations, so applicability to the United States is uncertain. ${ }^{65}$ Multiple well-designed studies are underway, including the Helping to End Addiction Long-term ${ }^{\mathrm{SM}}$ (HEAL) Initiative that will test a variety of interventions in multiple settings across the States. Study measures will include assessment of retention at 6 months to provide much-needed evidence in this area. ${ }^{6}$

\section{Contingency Management}

Our review found that CM interventions may improve retention for patients taking antagonist MAT, but not agonist MAT. A prior SR similarly did not identify benefit of these interventions with agonist and partial agonist MAT (methadone and buprenorphine). ${ }^{16}$ Our review included studies that used antagonist (naltrexone) MAT.

The type of MAT may be important in CM intervention effectiveness. Introduction of an outside reward may be of limited value in agonist and partial-agonist MAT, in which the medication provides some self-reinforcing effects (i.e., relief from withdrawal symptoms), compared with antagonist MAT, in which the medication does not provide any desired drug effects that may promote continued MAT use. ${ }^{68}$ This could partially explain the positive effects on retention in all studies with a CM intervention for naltrexone treatment, and the noneffect on retention in studies that employed methadone or buprenorphine MAT. 
Additionally, features of the CM intervention used in the studies that demonstrated an effect on retention may have contributed to the effectiveness of the intervention, including the type of response required to meet the contingency and the salience of the reward..$^{69}$ In the studies that reported improved retention, the behavior rewarded was adherence to prescribed MAT medication dosages, whereas, in the studies without effects, the behavior that was rewarded was primarily drug use abstinence. Further, the reward, access to a workplace where participants could gain work skills and earn vouchers to exchange for goods and services, was provided in close proximity to the location of the reward and free of charge, which may have limited some of the barriers to meeting the contingency criteria. Future studies might optimize effectiveness of CM interventions by maximizing the value of the reward to the participant (i.e., individualizing rewards) and optimizing the response required by the participant to meet the contingency (i.e., minimizing MAT costs and transportation effort).

Despite the demonstrated benefit of access to a workplace contingent upon taking naltrexone, these studies were small and were all conducted at one study site (in Baltimore, Maryland), raising concern for applicability to other settings. Further, such interventions may be difficult to implement in real-world settings due to cost, concerns that they may interfere with intrinsic motivation, and durability of effect. ${ }^{67}$

\section{Health IT}

We found very few published studies of IT interventions and no published evaluations of commercially available apps to improve MAT retention. Overall, studies reported no worse retention rates with IT approaches than with in-person approaches. Recognizing that there are few addiction specialists and counselors and that most are concentrated in urban areas, IT is promising for those with access to computers/internet, but questions remain on how to implement these programs at scale. The NIH NIDA Clinical Trials Network (CTN) study "Rural Expansion of Medication Treatment for Opioid Use Disorder" (CTN-102 Rural MOUD) plans to conduct an RCT evaluating the comparative effectiveness between office-based opioid treatment (OBOT) alone and OBOT plus telemedicine in highly impacted rural areas. The primary outcome is number of patient-days of buprenorphine treatment retention in the year following intervention implementation. ${ }^{70}$

Ongoing research is beginning to examine wearables and GPS monitoring capabilities to provide patients with increasing self-management and predictive analytics that can anticipate problems and offer real-time strategies and resources to avoid return to use. The AHRQ-funded project "Increasing Access to Medication-Assisted Treatment of Opioid Abuse in Rural Primary Care Practices” (https://integrationacademy.ahrq.gov/about/opioids-substance-use/ primary-care-medication-assisted-treatment-grantees) leverages smartphone apps, virtual training, telementoring, and consultations through Project Extensions for Community Healthcare Outcomes (Project ECHO) to support rural PC practices in five States in delivering MAT. The project started in 2016 and should have helpful data in the next few years.

It is concerning that commercially available apps do not have published evaluations. Because IT interventions have undergone few trials and many of those are pilots, future research should focus on studies with long-term outcomes (beyond 3 months), with sample sizes adequate to demonstrate true equivalence, and with blinded outcome assessors. Such studies should consider potential harms as well as benefits and process issues (e.g., connectivity or software compatibility) for patients, clinicians, and clinical settings. 


\section{Extended-Release Medication-Based Treatment for OUD}

XR formulations are conceptually attractive to increase MAT retention because they do not require daily administration. One of the two XR medications available in the United States, XR-naltrexone, is a mu opioid receptor antagonist that provides long-lasting blockade of opioid receptors. The other, XR-buprenorphine, is an opioid receptor partial agonist that reduces withdrawal symptoms without decreased opioid tolerance. Unlike naltrexone, buprenorphine does not require a period of complete abstinence from opioids to initiate treatment and is used to manage acute opioid withdrawal and as long-term treatment of OUD.

Similar to a prior review, ${ }^{55}$ we found inconsistent results for treatment retention with XR-naltrexone injection vs. daily MAT formulations. Our review also included recent studies that compared XR and daily buprenorphine that showed no statistically significant differences in retention between the two formulations. $\underline{30}, \underline{31}$

The lack of studies comparing XR formulations head-to-head highlights the need for future comparative effectiveness trials that may change conclusions. We also identified study design issues related to patient selection, timing of randomization relative to completion of supervised withdrawal, and medically supervised withdrawal procedures that affected the study findings' applicability and generalizability. Additional studies of XR-buprenorphine in real-world settings could be useful to address limitations of XR-naltrexone and other antagonist therapies that require a period of complete abstinence from opioids for treatment initiation. Future studies should also use treatment-based controls.

Few studies in our review examined how participant characteristics affected retention, though there was evidence that those with lower opioid use severity or comorbid alcohol use were more likely to complete medically supervised opioid withdrawal and thus may benefit more from XR-naltrexone formulations. ${ }^{30}$ XR formulations could be particularly effective in some patient populations such as those at high risk of unforeseen treatment disruptions (such as homelessness or incarceration), those at risk for medication diversion and misuse, populations at risk for access disruptions or who live in remote areas, and those concerned about the stigma or inconvenience of daily maintenance therapy. Several ongoing trials may add to this evidence. For example, the NIH NIDA CTN “Retention-Duration-Discontinuation” trial (CTN-100 RDD Study) is currently in progress. ${ }^{71}$ This multisite, multi-arm trial enrolls 1,800 participants with OUD across 20 large outpatient OUD treatment clinics nationwide, provides the participants with a choice of buprenorphine or XR-naltrexone, and follows participants for 2 years, with MAT retention at 6 months as the primary retention outcome. ${ }^{72}$ It will assess the optimal duration and discontinuation of MAT. The results of these trials should help demonstrate whether long-acting formulations can improve retention outcomes.

\section{Psychosocial Support}

Our review of psychosocial support interventions (not including CM) largely aligns with the prior SR that found no effect on retention. ${ }^{16}$ The lack of observed differences between the experimental and control groups may be explained by the inclusion of psychosocial support in the control groups. Of note, eight of nine studies reviewed had control groups that received elements of psychosocial support through counseling, ${ }^{32,34-36} 12$-step programs, ${ }^{40}$ self-help groups, ${ }^{37,39}$ or $\mathrm{CM},{ }^{38}$ and one study did not sufficiently describe their control. ${ }^{33}$ Further, researchers could employ attention control groups (e.g., controls that receive an intervention that 
mimics the amount of time and attention received by the treatment group but is not thought to exert effect) to reduce bias that may arise from participant awareness of assignment.

\section{Financial Support}

We did not find studies of financial interventions to improve MAT retention that met our inclusion criteria, suggesting an area for future study. We identified, however, studies of financial interventions that measured other outcomes that may give suggestions for future studies. A mixed-methods study involving stakeholder and focus group interviews examining the impact of out-of-pocket pharmacy costs on medication adherence identified out-of-pocket pharmacy costs for MAT as a barrier for continued treatment retention; ${ }^{73}$ another observational study evaluating the impact of Medicaid expansion of MAT coverage found reductions in opioid use-related healthcare utilization, but did not measure retention. ${ }^{74}$ Similarly, a cohort time-series analysis of a dose-based prior authorization policy for buprenorphine by Massachusetts Medicaid found that the policy implementation led to increased treatment dropout and significant increases in relapse rates among those prescribed higher doses of buprenorphine. ${ }^{75}$

\section{Future Directions}

Our review provides opportunities to inform future research. First, there is a need for a standardized definition of MAT retention. While evidence suggests that retention in MAT may be key in improving OUD outcomes, ${ }^{44}$ MAT retention was the primary outcome in fewer than half of the studies we reviewed. Definitions of retention varied widely, from number of days until dropout from study medication ${ }^{4-6,25,27,30,31,36,38,76}$ to proportion of participants remaining in treatment at 12 months; , 9, 22 there was variability in how investigators assessed retention outcomes, and studies often were not clear in how retention was defined, making comparisons difficult.

Ideally, a standardized definition of retention might have specified parameters around 1) duration of participation in MAT, 2) degree of participation (e.g., if discontinuous, to what degree of discontinuity is acceptable), 3) and measurement of retention (e.g., urine screen for presence of MAT medication, patient self-report).

Second, future research would benefit from study designs that improve applicability and generalizability. Future trials should enroll diverse groups of participants that are representative of the heterogeneous population of OUD patients and be conducted in a variety of practice settings to more closely resemble "real-world" conditions. Additionally, future studies should consider patient preferences for either agonist, partial agonist, or antagonist forms of MAT and design trials to allow for patient preference in assigning treatment. Some studies we reviewed were conducted outside of the United States, where policies and practices differ, limiting generalizability.

In addition to improving generalizability, future studies would benefit from improved internal validity. While blinding of investigators and providers delivering MAT is generally not practical for most interventions, other methodological approaches such as blinding outcome assessors are almost always possible and should be performed. Large-scale ongoing implementation studies, such as the CTN-100 RDD study ${ }^{70}$ that allows for patient preference and compares multiple retention strategies across a diverse array of real-world treatment settings, hold promise to inform clinical practice and public health policy. 


\section{Limitations of the Review}

Our review has several limitations. We were not able to review every intervention proposed to improve retention in MAT. Instead, we focused the scope of our review based on stakeholder input. We did not include non-RCT study designs, with few exceptions, and excluded RCTs that used placebo or non-MAT comparator groups, which required excluding studies of some interventions. We used a rapid review methodology, which involved searching limited databases, not conducting formal meta-analyses, and including findings from existing published SRs. Consistent with the rapid review standard practice, we used existing SRs to define the categories of interventions to include into our review. We did not conduct a formal assessment of strength-of-evidence assessment (e.g., publication bias assessment, differing tools for quality assessment), as we relied on the existing strength-of-evidence assessments provided within the included SRs.

The interventions we reviewed were broad and diverse, which limited comparisons across studies. Further, we included only those studies that measured retention for at least 3 months. A 3-month requirement was recommended by content experts as the minimum clinically relevant study duration to assess retention. Longer studies are needed to ascertain the sustained effects of various interventions on treatment retention; however. few studies identified in our search continued beyond 3 months. Finally, our review focused predominantly on the outcome of treatment retention. When considering healthcare or policy decisions, it would be important to consider other relevant outcomes, such as mortality and morbidity outcomes, access to treatment, as well as quality of life and other patient-centered outcomes.

\section{Conclusions}

In our review of the current evidence, we found few studies that assessed MAT retention as a primary outcome, and less evidence on harms of interventions and patient characteristics associated with differential effectiveness of the interventions. We found that retention in MAT may be improved through several avenues, including use of integrated care settings with criminal justice populations, and use of CM interventions for patients on antagonist MAT. Preliminary studies suggest that alternative means of care delivery (health IT) and integration of medical, psychiatric, and social services with MAT may not worsen retention outcomes. While the few comparative effectiveness studies to date show no difference in retention between XR formulations and SL daily formulations, this evidence is evolving. There are several areas for which future research is needed, given the paucity of controlled studies, including the use of IT interventions, telehealth-delivered MAT, and interventions to reduce the financial barriers to care. Overall, there is a critical need for better quality studies and explicit attention to harms as well as benefits. Because retention is associated with improved outcomes, future OUD research should develop standard measures for retention to be used in reporting results. 


\section{References}

1. Hedrich D, Alves P, Farrell M, et al. The effectiveness of opioid maintenance treatment in prison settings: a systematic review. Addiction. 2012;107(3):501-17. doi: https://dx.doi.org/10.1111/ j.1360-0443.2011.03676.x. PMID: 21955033.

2. Friedmann PD, Wilson D, Hoskinson R, Jr., et al. Initiation of extended release naltrexone (XR-NTX) for opioid use disorder prior to release from prison. J Subst Abuse Treat. 2018;85:45-8. doi: https://dx.doi.org/10.1016/ j.jsat.2017.04.010. PMID: 28527855.

3. Gordon MS, Kinlock TW, Schwartz RP, et al. A randomized clinical trial of buprenorphine for prisoners: Findings at 12-months post-release. Drug and alcohol dependence. 2017;172:34-42. doi: https://dx.doi.org/10.1016/ j.drugalcdep.2016.11.037. PMID: 28107680.

4. Brooner RK, Kidorf MS, King VL, et al. Managing psychiatric comorbidity within versus outside of methadone treatment settings: a randomized and controlled evaluation. Addiction. 2013;108(11):1942-51. doi: https://dx.doi.org/10.1111/add.12269. PMID: 23734943.

5. Carrieri PM, Michel L, Lions C, et al. Methadone induction in primary care for opioid dependence: a pragmatic randomized trial (ANRS Methaville). PLoS ONE [Electronic Resource]. 2014;9(11):e112328. doi: https://dx.doi.org/10.1371/ journal.pone.0112328. PMID: 25393311.

6. Miotto K, Hillhouse M, Donovick R, et al. Comparison of buprenorphine treatment for opioid dependence in 3 settings. J Addict Med. 2012;6(1):68-76. doi: https://dx.doi.org/10.1097/ ADM.0b013e318233d621. PMID: 22105061.
7. Liebschutz JM, Crooks D, Herman D, et al. Buprenorphine treatment for hospitalized, opioid-dependent patients: a randomized clinical trial. JAMA Intern Med. 2014;174(8):1369-76. doi: https://dx.doi.org/10.1001/ jamainternmed.2014.2556. PMID: 25090173.

8. D'Onofrio G, Chawarski MC, O'Connor PG, et al. Emergency Department-Initiated Buprenorphine for Opioid Dependence with Continuation in Primary Care: Outcomes During and After Intervention. Journal of General Internal Medicine. 2017;32(6):660-6. doi: https://dx.doi.org/10.1007/ s11606-017-3993-2. PMID: 28194688.

9. Schwartz RP, Kelly SM, Mitchell SG, et al. Patient-centered methadone treatment: a randomized clinical trial. Addiction. 2017;112(3):454-64. doi: https://dx.doi.org/10.1111/add.13622. PMID: 27661788.

10. Beattie A, Marques EM, Barber M, et al. Script in a Day intervention for individuals who are injecting opioids: a feasibility randomized control trial. J Public Health (Oxf). 2015;38(4):712-21. doi: https://dx.doi.org/10.1093/pubmed/fdv161. PMID: 28158697.

11. Kidorf M, Brooner RK, Leoutsakos JM, et al. Treatment initiation strategies for syringe exchange referrals to methadone maintenance: A randomized clinical trial. Drug and alcohol dependence. 2018;187:343-50. doi: https://dx.doi.org/10.1016/ j.drugalcdep.2018.03.009. PMID: 29709732.

12. Parpouchi M, Moniruzzaman A, Rezansoff SN, et al. The effect of Housing First on adherence to methadone maintenance treatment. The International journal on drug policy. 2018;56:73-80. doi: https://dx.doi.org/10.1016/ j.drugpo.2018.03.012. PMID: 29609153. 
13. Everly JJ, DeFulio A, Koffarnus MN, et al. Employment-based reinforcement of adherence to depot naltrexone in unemployed opioid-dependent adults: a randomized controlled trial. Addiction. 2011;106(7):1309-18. doi: https://dx.doi.org/10.1111/ j.1360-0443.2011.03400.x. PMID: 21320227.

14. DeFulio A, Everly JJ, Leoutsakos JM, et al. Employment-based reinforcement of adherence to an FDA approved extended release formulation of naltrexone in opioid-dependent adults: a randomized controlled trial. Drug and alcohol dependence. 2012;120(1-3):48-54. doi: https://dx.doi.org/10.1016/ j.drugalcdep.2011.06.023. PMID: 21782353.

15. Dunn KE, Defulio A, Everly JJ, et al. Employment-based reinforcement of adherence to oral naltrexone treatment in unemployed injection drug users. Exp Clin Psychopharmacol. 2013;21(1):74-83. doi: https://dx.doi.org/10.1037/a0030743. PMID: 23205722.

16. Amato L, Minozzi S, Davoli M, et al. Psychosocial combined with agonist maintenance treatments versus agonist maintenance treatments alone for treatment of opioid dependence. Cochrane Database Syst Rev. 2011(10):CD004147. doi: https://dx.doi.org/10.1002/ 14651858.CD004147.pub4. PMID: 21975742.

17. Holtyn AF, Koffarnus MN, DeFulio A, et al. The therapeutic workplace to promote treatment engagement and drug abstinence in out-of-treatment injection drug users: a randomized controlled trial. Prev Med. 2014 Nov;68:62-70. doi: https://dx.doi.org/10.1016/ j.ypmed.2014.02.021. PMID: 24607365.

18. Epstein DH, Schmittner J, Umbricht A, et al. Promoting abstinence from cocaine and heroin with a methadone dose increase and a novel contingency. Drug and alcohol dependence. 2009;101(1-2):92-100. doi: https://dx.doi.org/10.1016/ j.drugalcdep.2008.11.006. PMID: 19101098.
19. Specka M, Boning A, Kluwig J, et al. Can reinforcement-based interventions to reduce drug use successfully be adapted to routine opioid maintenance treatment? Ann Ist Super Sanita. 2013;49(4):358-64. doi: https://dx.doi.org/10.4415/ANN_13_04_07. PMID: 24334780.

20. Eibl JK, Gauthier G, Pellegrini D, et al. The effectiveness of telemedicine-delivered opioid agonist therapy in a supervised clinical setting. Drug and alcohol dependence. 2017;176:133-8. doi: https://dx.doi.org/10.1016/ j.drugalcdep.2017.01.048. PMID: 28535455.

21. Weintraub E, Greenblatt AD, Chang J, et al. Expanding access to buprenorphine treatment in rural areas with the use of telemedicine. The American journal on addictions. 2018;27(8):612-7. doi: https://dx.doi.org/10.1111/ajad.12805. PMID: 30265425

22. Zheng $\mathrm{W}$, Nickasch $\mathrm{M}$, Lander L, et al. Treatment Outcome Comparison Between Telepsychiatry and Face-to-face Buprenorphine Medication-assisted Treatment for Opioid Use Disorder: A 2-Year Retrospective Data Analysis. J Addict Med. 2017;11(2):138-44. doi: https://dx.doi.org/10.1097/ ADM.0000000000000287. PMID: 28107210.

23. Moore BA, Buono FD, Lloyd DP, et al. A randomized clinical trial of the Recovery Line among methadone treatment patients with ongoing illicit drug use. J Subst Abuse Treat. 2019;97:68-74. doi: https://dx.doi.org/10.1016/j.jsat.2018. PMID: 30577901.

24. Shi JM, Henry SP, Dwy SL, et al. Randomized pilot trial of Web-based cognitive-behavioral therapy adapted for use in office-based buprenorphine maintenance. Subst Abuse. 2019:1-4. doi: https://dx.doi.org/10.1080/ 08897077.2019.1569192. PMID: 30714880.

25. Marsch LA, Guarino H, Acosta M, et al. Web-based behavioral treatment for substance use disorders as a partial replacement of standard methadone maintenance treatment. J Subst Abuse Treat. 2014;46(1):43-51. doi: https://dx.doi.org/10.1016/ j.jsat.2013.08.012. PMID: 24060350. 
26. Ruetsch C, Tkacz J, McPherson TL, et al. The effect of telephonic patient support on treatment for opioid dependence: outcomes at one year follow-up. Addictive Behaviors. 2012;37(5):686-9. doi:

https://dx.doi.org/10.1016/

j.addbeh.2012.01.013. PMID: 22348921.

27. Sullivan MA, Bisaga A, Pavlicova M, et al. A Randomized Trial Comparing Extended-Release Injectable Suspension and Oral Naltrexone, Both Combined With Behavioral Therapy, for the Treatment of Opioid Use Disorder. Am J Psychiatry. 2019;176(2):129-37. doi:

https://dx.doi.org/10.1176/ appi.ajp.2018.17070732. PMID: 30336703.

28. Lofwall MR, Walsh SL, Nunes EV, et al. Weekly and Monthly Subcutaneous Buprenorphine Depot Formulations vs Daily Sublingual Buprenorphine With Naloxone for Treatment of Opioid Use Disorder: A Randomized Clinical Trial. JAMA Intern Med. 2018;178(6):764-73. doi:

https://dx.doi.org/10.1001/ jamainternmed.2018.1052. PMID: 29799968.

29. Rosenthal RN, Lofwall MR, Kim S, et al. Effect of Buprenorphine Implants on Illicit Opioid Use Among Abstinent Adults With Opioid Dependence Treated With Sublingual Buprenorphine: A Randomized Clinical Trial. JAMA. 2016;316(3):282-90. doi:

https://dx.doi.org/10.1001/jama.2016.9382. PMID: 27434441.

30. Lee JD, Nunes EV, Jr., Novo P, et al. Comparative effectiveness of extended-release naltrexone versus buprenorphine-naloxone for opioid relapse prevention (X:BOT): a multicentre, open-label, randomised controlled trial. Lancet. 2018;391(10118):309-18. doi: https://dx.doi.org/10.1016/ S0140-6736(17)32812-X. PMID: 29150198.
31. Tanum L, Solli KK, Latif ZE, et al. Effectiveness of Injectable Extended-Release Naltrexone vs Daily Buprenorphine-Naloxone for Opioid Dependence: A Randomized Clinical Noninferiority Trial. JAMA Psychiatry. 2017;74(12):1197-205. doi: https://dx.doi.org/10.1001/ jamapsychiatry.2017.3206. PMID: 29049469.

32. Christensen DR, Landes RD, Jackson L, et al. Adding an Internet-delivered treatment to an efficacious treatment package for opioid dependence. J Consult Clin Psychol. 2014;82(6):964-72. doi: https://dx.doi.org/10.1037/a0037496. PMID: 25090043.

33. Jaffray M, Matheson C, Bond CM, et al. Does training in motivational interviewing for community pharmacists improve outcomes for methadone patients? A cluster randomised controlled trial. The International journal of pharmacy practice. 2014;22(1):4-12. doi: https://dx.doi.org/10.1111/ijpp.12049. PMID: 23822820.

34. Mitchell SG, Gryczynski J, Schwartz RP, et al. A randomized trial of intensive outpatient (IOP) vs. standard outpatient (OP) buprenorphine treatment for African Americans. Drug and alcohol dependence. 2013;128(3):222-9. doi: https://dx.doi.org/10.1016/ j.drugalcdep.2012.08.027. PMID: 22999817.

35. Schwartz RP, Kelly SM, O'Grady KE, et al. Randomized trial of standard methadone treatment compared to initiating methadone without counseling: 12-month findings. Addiction. 2012;107(5):943-52. doi: https://dx.doi.org/10.1111/ j.1360-0443.2011.03700.x. PMID: 22029398.

36. Sullivan MA, Bisaga A, Glass A, et al. Opioid use and dropout in patients receiving oral naltrexone with or without single administration of injection naltrexone. Drug and alcohol dependence. 2015;147:122-9. doi: https://dx.doi.org/10.1016/ j.drugalcdep.2014.11.028. PMID: 25555621. 
37. Weiss RD, Potter JS, Fiellin DA, et al. Adjunctive counseling during brief and extended buprenorphine-naloxone treatment for prescription opioid dependence: a 2-phase randomized controlled trial. Arch Gen Psychiatry. 2011;68(12):1238-46. doi: https://dx.doi.org/10.1001/ archgenpsychiatry.2011.121. PMID: 22065255

38. Marsden J, Stillwell G, James K, et al. Efficacy and cost-effectiveness of an adjunctive personalised psychosocial intervention in treatment-resistant maintenance opioid agonist therapy: a pragmatic, open-label, randomised controlled trial. Lancet Psychiatry. 2019;6(5):391-402. doi: https://dx.doi.org/10.1016/ S2215-0366(19)30097-5. PMID: 30952568.

39. Fiellin DA, Barry DT, Sullivan LE, et al. A randomized trial of cognitive behavioral therapy in primary care-based buprenorphine. Am J Med. 2013;126(1):74.e11-7. doi: https://dx.doi.org/10.1016/ j.amjmed.2012.07.005. PMID: 23260506.

40. Stein MD, Herman DS, Moitra E, et al. A preliminary randomized controlled trial of a distress tolerance treatment for opioid dependent persons initiating buprenorphine. Drug and alcohol dependence.

2015;147:243-50. doi:

https://dx.doi.org/10.1016/

j.drugalcdep.2014.11.007. PMID: 25510307.

41. Substance Abuse and Mental Health

Services Administration. TIP 63:

Medications for Opioid Use Disorder

42. Scholl L, Seth P, Kariisa M, et al. Drug and opioid-involved overdose deaths-United States, 2013-2017. MMWR Morbidity and mortality weekly report. 2019;67(5152):1419. doi: https://dx.doi.org/10.15585/ mmwr.mm675152e1. PMID: 30605448

43. Van Handel MM, Rose CE, Hallisey EJ, et al. County-level vulnerability assessment for rapid dissemination of HIV or HCV infections among persons who inject drugs, United States. J Acquir Immune Defic Syndr. 2016;73(3):323. doi: https://dx.doi.org/10.1097/ QAI.0000000000001098. PMID: 27763996
44. National Academies of Sciences, Engineering, and Medicine. Medications for Opioid Use Disorder Save Lives. Washington, DC: The National Academies Press 2019. doi: https://doi.org/10.17226/25310. PMID: 30896911.

45. Ma J, Bao YP, Wang RJ, et al. Effects of medication-assisted treatment on mortality among opioids users: a systematic review and meta-analysis. Mol Psychiatry. 2018;22:22. doi: https://dx.doi.org/10.1038/ s41380-018-0094-5. PMID: 29934549.

46. Sordo L, Barrio G, Bravo MJ, et al. Mortality risk during and after opioid substitution treatment: systematic review and meta-analysis of cohort studies. BMJ. 2017;357:j1550. doi: https://dx.doi.org/10.1136/bmj.j1550. PMID: 28446428

47. Volkow ND, Jones EB, Einstein EB, et al. Prevention and treatment of opioid misuse and addiction: a review. JAMA Psychiatry. 2019;76(2):208-16. doi: https://dx.doi.org/10.1001/ jamapsychiatry.2018.3126. PMID: 30516809

48. Timko C, Schultz NR, Cucciare MA, et al. Retention in medication-assisted treatment for opiate dependence: A systematic review. J of Addict Dis. 2016;35(1):22-35. doi: https://dx.doi.org/10.1080/ 10550887.2016.1100960. PMID: 26467975.

49. Kourounis G, Richards BD, Kyprianou E, et al. Opioid substitution therapy: Lowering the treatment thresholds. Drug and alcohol dependence. 2016;161:1-8. doi: https://dx.doi.org/10.1016/ j.drugalcdep.2015.12.021. PMID: 26832931.

50. Larochelle MR, Bernson D, Land T, et al. Medication for Opioid Use Disorder After Nonfatal Opioid Overdose and Association With Mortality: A Cohort Study. Ann Intern Med. 2018 Aug 7;169(3):137-45. doi: 10.7326/m17-3107. PMID: 29913516.

51. Wakeman SE, Larochelle MR, Ameli O, et al. Comparative Effectiveness of Different Treatment Pathways for Opioid Use Disorder. JAMA Netw Open. 2020 Feb 5;3(2):e1920622. doi: 10.1001/jamanetworkopen.2019.20622. PMID: 32022884. 
52. Tricco AC, Langlois E, Straus SE, et al. Rapid reviews to strengthen health policy and systems: a practical guide: World Health Organization; 2017.

53. Chan B, Gilbert, J., Gean, E., et. al. A rapid evidence review of retention strategies for medications for addiction treatment (MAT) in adults with opioid use disorder. PROSPERO. 2019;CRD42019134739. doi: https://www.crd.york.ac.uk/PROSPERO/ display record.php?RecordID=134739.

54. Chan B, Gean E, Arkhipova-Jenkins I, et al. Protocol: A rapid evidence review of retention strategies for medications for addiction treatment (MAT) in adults with opioid use disorder. A research protocol. Rockville, MD: AHRQ Effective Health Care Program 2019. https://effectivehealthcare.ahrq.gov/ products/retention-strategies-opioid-use -disorder/rapid-protocol. Accessed on October 9, 2019.

55. Jarvis BP, Holtyn AF, Subramaniam S, et al. Extended-release injectable naltrexone for opioid use disorder: a systematic review. Addiction. 2018;113(7):1188-209. doi: https://dx.doi.org/10.1111/add.14180. PMID: 29396985.

56. Office of the National Coordinator for Health IT. Section 4: Opioid epidemic and health IT. In Health IT playbook. 2016. Available from: https://www.healthit.gov/playbook/ opioid-epidemic-and-health-it/.

57. Viswanathan M, Patnode CD, Berkman ND, et al. Assessing the risk of bias in systematic reviews of health care interventions. Methods guide for effectiveness and comparative effectiveness reviews [Internet]. Agency for Healthcare Research and Quality (US); 2017.

58. Korthuis PT, McCarty D, Weimer M, et al. Primary care-based models for the treatment of opioid use disorder: A scoping review. Ann Intern Med. 2017;166(4):268-78. doi: https://dx.doi.org/10.7326/M16-2149. PMID: 27919103.
59. Dunn K, DeFulio A, Everly JJ, et al. Employment-based reinforcement of adherence to oral naltrexone in unemployed injection drug users: 12-month outcomes. Psychology of addictive behaviors : journal of the Society of Psychologists in Addictive Behaviors. 2015 Jun;29(2):270-6. doi: https://dx.doi.org/10.1037/adb0000010. PMID: 25134047.

60. Ruetsch C, Cacciola J, Tkacz J. A national study of a telephone support service for patients receiving office-based buprenorphine medication-assisted treatment: study feasibility and sample description. J Subst Abuse Treat. 2010;39(4):307-17. doi: https://dx.doi.org/10.1016/ j.jsat.2010.07.003. PMID: 20728299.

61. King VL, Brooner RK, Peirce JM, et al. A randomized trial of Web-based videoconferencing for substance abuse counseling. J Subst Abuse Treat. 2014;46(1):36-42. doi: https://dx.doi.org/10.1016/ j.jsat.2013.08.009. PMID: 24035556.

62. Kim SJ, Marsch LA, Guarino H, et al. Predictors of outcome from computer-based treatment for substance use disorders: Results from a randomized clinical trial. Drug and alcohol dependence. 2015 Dec 1;157:174-8. doi: https://dx.doi.org/10.1016/ j.drugalcdep.2015.09.019. PMID: 26433562.

63. Chandler RK, Fletcher BW, Volkow ND. Treating drug abuse and addiction in the criminal justice system: improving public health and safety. Jama. 2009;301(2):183-90.

64. Binswanger IA, Blatchford PJ, Mueller SR, et al. Mortality after prison release: opioid overdose and other causes of death, risk factors, and time trends from 1999 to 2009. Ann Intern Med. 2013;159(9):592-600. doi: https://dx.doi.org/10.7326/ 0003-4819-159-9-201311050-00005. PMID: 24189594

65. Administration SAaMHS. Federal Guidelines for Opioid Treatment Programs. January 2015. doi: https://store.samhsa.gov/system/files/ pep15-fedguideotp.pdf. 
66. National Institute of Health. NIH funds study in four states to reduce opioid related deaths by 40 percent over three years. https://www.nih.gov/news-events/ news-releases/nih-funds-study-four-states -reduce-opioid-related-deaths-40-percent -over-three-years; 2019

67. Petry NM, Alessi SM, Olmstead TA, et al. Contingency management treatment for substance use disorders: How far has it come, and where does it need to go? Psychology of addictive behaviors : journal of the Society of Psychologists in Addictive Behaviors. 2017 Dec;31(8):897-906. doi: 10.1037/adb0000287. PMID: 28639812.

68. Walsh SL, Preston KL, Bigelow GE, et al. Acute administration of buprenorphine in humans: partial agonist and blockade effects. J Pharmacol Exp Ther. 1995;274(1):361-72. PMID: 7542336.

69. Petry NM. A comprehensive guide to the application of contingency management procedures in clinical settings. Drug and alcohol dependence. 2000;58:9-25. doi: https://dx.doi.org/10.1016/ s0376-8716(99)00071-x. PMID: 10669051

70. National Institute of Health. Rural Expansion of Medication Treatment for Opioid Use Disorder (NIH HEAL Initiative). 2019.

https://www.drugabuse.gov/ about-nida/organization/cctn/ctn/ research-studies/rural-expansion -medication-treatment-opioid-use-disorder -nih-heal-initiative.

71. Campbell AN, Nunes EV, Matthews AG, et al. Internet-delivered treatment for substance abuse: a multisite randomized controlled trial. Am J Psychiatry. 2014;171(6):683-90. doi: https://dx.doi.org/10.1176/ appi.ajp.2014.13081055. PMID: 24700332

72. National Institute of Health. Optimizing Retention, Duration, and Discontinuation Strategies for Opioid Use Disorder Pharmacotherapy (NIH HEAL Initiative). 2019. https://www.drugabuse.gov/ about-nida/organization/cctn/ctn/ research-studies/optimizing-retention -duration-discontinuation-strategies-opioid -use-disorder-pharmacotherapy-nih.
73. Leslie DL, Milchak W, Gastfriend DR, et al. Effects of injectable extended-release naltrexone (XR-NTX) for opioid dependence on residential rehabilitation outcomes and early follow-up. American Journal on Addictions. 2015;24(3):265-70. PMID: 25655226.

74. Wen H, Hockenberry JM, Borders TF, et al. Impact of Medicaid Expansion on Medicaid-covered Utilization of Buprenorphine for Opioid Use Disorder Treatment. Med Care. 2017 Apr;55(4):336-41. doi: https://dx.doi.org/10.1097/ mlr.0000000000000703. PMID: 28296674.

75. Clark RE, Baxter JD, Barton BA, et al. The impact of prior authorization on buprenorphine dose, relapse rates, and cost for Massachusetts Medicaid beneficiaries with opioid dependence. Health Serv Res. 2014 Dec;49(6):1964-79. doi: https://dx.doi.org/10.1111/ 1475-6773.12201. PMID: 25040021.

76. Gordon MS, Vocci FJ, Fitzgerald TT, et al. Extended-release naltrexone for pre-release prisoners: A randomized trial of medical mobile treatment. Contemporary Clinical Trials. 2017;53:130-6. PMID: 28011389. 


\section{Abbreviations and Acronyms}

AHRQ

BNT

CBT

CI

$\mathrm{CM}$

CRA

CTN

ECHO

ED

EPC

FDA

GPS

GRADE

HEAL

HHS

HR

$\mathrm{HTH}$

IRR

IT

ITT

LAAM

MAT

NASEM

MOUD

MPR

NIDA

$\mathrm{NIH}$

NR

NS

OBOT

OR

OUD

PC

PICOTS

RCT

RR

SAMHSA
Agency for Healthcare Research and Quality

Behavioral Naltrexone Therapy

cognitive behavioral therapy

confidence interval

contingency management

Community Reinforcement Approach

Clinical Trials Network

Extensions for Community Healthcare Outcomes

emergency department

Evidence-based Practice Center

Food and Drug Administration

Global Positioning System

Grading of Recommendations Assessment, Development and Evaluation

Helping to End Addiction Long-term

Department of Health and Human Services

hazard ratio

Here To Help

incidence rate ratio

information technology

intention-to-treat

levo-alpha acetyl methadol

medication(s) for addiction treatment

National Academies of Sciences, Engineering, and Medicine

medication treatment for opioid use disorder

medication possession ratio

National Institute on Drug Abuse

National Institutes of Health

not reported

not significant

office-based opioid treatment

odds ratio

opioid use disorder

primary care

population, intervention, comparator, outcomes, timing, setting

randomized controlled trial

risk ratio

Substance Abuse and Mental Health Services Administration 
SD

SL

SR

SUD

TAU

TOO

WHO

XR

standard deviationSE standard error

sublingual

systematic review

substance use disorder

treatment as usual

Task Order Officer

World Health Organization

extended-release 


\section{Appendix A. Search Strategy}

Ovid MEDLINE(R) and Epub Ahead of Print, In-Process \& Other Non-Indexed Citations and Daily 2009 to June 16, 2019

\begin{tabular}{|c|c|c|}
\hline$\#$ & Searches & Results \\
\hline 1 & $\begin{array}{l}\text { Opioid-Related Disorders/ or Heroin Dependence/ or Morphine } \\
\text { Dependence/ or Opium Dependence/ or Substance-Related Disorders/ }\end{array}$ & 112848 \\
\hline 2 & $\begin{array}{l}\text { ((carfentanyl or codeine or fentanyl or heroin or hydrocodone or } \\
\text { hydromorphone or morphine or opioid or opiate* or opium or oxycodone } \\
\text { or substance) adj3 (abuse* or addict* or depend* or disorder* or } \\
\text { misuse* or user or users)).ti,ab,kf. }\end{array}$ & 55392 \\
\hline 3 & or/1-2 & 132763 \\
\hline 4 & $\begin{array}{l}\text { Opiate Substitution Treatment/ or Buprenorphine/ or Buprenorphine, } \\
\text { Naloxone Drug Combination/ or Methadone/ or Naloxone/ or } \\
\text { Naltrexone/ or (dt or th or rh or tu).fs. }\end{array}$ & 4399399 \\
\hline 5 & $\begin{array}{l}\text { ("alpha-2 agonist*" or "opioid agonist" or "opioid antagonist" or } \\
\text { buprenorphine or LAAM or "Levomethadyl acetate" or "medication } \\
\text { assisted" or methadone or naloxone or naltrexone or ((opiate* or } \\
\text { opioid*) adj5 (maintenance or pharmacotherap* or pharmaco-therap* or } \\
\text { substitution or therap* or treat*))).ti,ab,kf. }\end{array}$ & 52155 \\
\hline 6 & $\begin{array}{l}\text { (Belbuca or Buprenex or Butrans or Diskets or Dolophine or Evzio or } \\
\text { Lofexidine or Methadose or Narcan or Revia or Suboxone or BUP-XR } \\
\text { or CAM2038 or INDV-6200 or Probuphine or RBP-6000 or Sublocade } \\
\text { or Vivitrol or depot or "extended release" or implant or long-acting or } \\
\text { "slow release" or "sustained release" or XR-NTR).ti,ab,kf. }\end{array}$ & 150777 \\
\hline 7 & or/4-6 & 4512344 \\
\hline 8 & $\begin{array}{l}\text { "Treatment Adherence and Compliance"/ or "Patient Acceptance of } \\
\text { Health Care"/ or Patient Compliance/ or Medication Adherence/ or No- } \\
\text { show Patients/ or Patient Dropouts/ or Recurrence/ or Social Support/ } \\
\text { or Treatment Refusal/ }\end{array}$ & 367217 \\
\hline
\end{tabular}




\begin{tabular}{|c|c|c|}
\hline$\#$ & Searches & Results \\
\hline 9 & $\begin{array}{l}\text { (attend* or attrition or abstain* or abstinen* or adhere* or non-adhere* } \\
\text { or nonadhere* or continu* or discontinu* or dropout* or drop-out* or } \\
\text { engag* or longer or "loss to followup" or "lost to followup" or month or } \\
\text { months or no-show or recovery or reengag* or re-engag* or relaps* or } \\
\text { retain* or retention or shorter or terminat* or year or years or detection } \\
\text { or wearable or wearables).ti,ab,kf. }\end{array}$ & 5973579 \\
\hline 10 & or/8-9 & 6135642 \\
\hline 11 & $\begin{array}{l}\text { exp telemedicine/ or exp "online systems"/ or exp internet/ or "cell } \\
\text { phones"/ or smartphone/ or "text messaging"/ or exp "mobile } \\
\text { applications"/ }\end{array}$ & 119185 \\
\hline 12 & 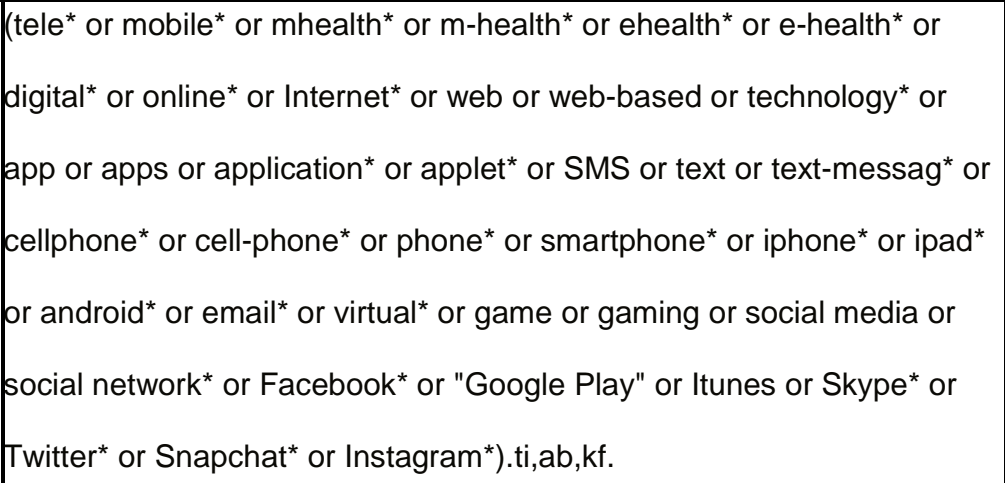 & 1623971 \\
\hline 13 & $\begin{array}{l}\text { ("Addiction CHESS" or "A-CHESS" or "COR-12" or FlexDekor or } \\
\text { "Opioid addiction recovery support app" or OARS or "Pear reSET- } \\
\text { O").ti,ab,kf. }\end{array}$ & 1355 \\
\hline 14 & or/11-13 & 1656439 \\
\hline 15 & 3 and 7 and 10 and 14 & 1913 \\
\hline 18 & limit 15 to $y r=" 2009$-Current" & 1164 \\
\hline
\end{tabular}

EBM Reviews (Ovid) - Cochrane Database of Systematic Reviews 2009 to June 16, 2019

Date searched: June 16, 2019

Searched by: Robin Paynter, MLIS 


\begin{tabular}{|c|c|c|}
\hline \# & Searches & Results \\
\hline 1 & $\begin{array}{l}\text { ((carfentanyl or codeine or fentanyl or heroin or hydrocodone or } \\
\text { hydromorphone or morphine or opioid or opiate* or opium or oxycodone) } \\
\text { adj3 (abuse* or addict* or depend* or disorder* or misuse* or user or } \\
\text { users)).ti,ab,kf. }\end{array}$ & 40 \\
\hline 2 & $\begin{array}{l}\text { ("alpha-2 agonist*" or "opioid agonist" or "opioid antagonist" or } \\
\text { buprenorphine or LAAM or "Levomethadyl acetate" or "medication assisted" } \\
\text { or methadone or naloxone or naltrexone or ((opiate* or opioid*) adj5 } \\
(\text { maintenance or pharmacotherap* or pharmaco-therap* or substitution or } \\
\text { therap* or treat*))).ti,ab,kf. }\end{array}$ & 104 \\
\hline 3 & $\begin{array}{l}\text { (Belbuca or Buprenex or Butrans or Diskets or Dolophine or Evzio or } \\
\text { Lofexidine or Methadose or Narcan or Revia or Suboxone or BUP-XR or } \\
\text { CAM2038 or INDV-6200 or Probuphine or RBP-6000 or Sublocade or } \\
\text { Vivitrol or depot or "extended release" or implant or long-acting or "slow } \\
\text { release" or "sustained release" or XR-NTR).ti,ab,kf. }\end{array}$ & 182 \\
\hline 4 & 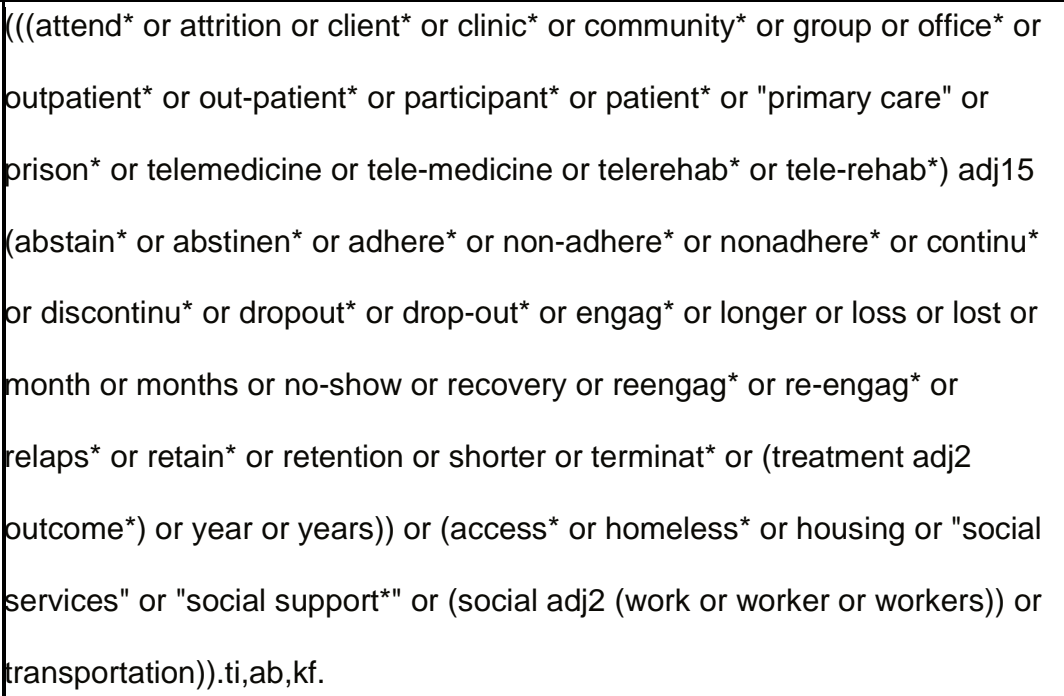 & 2485 \\
\hline 5 & $\mathrm{pr} / 2-3$ & 278 \\
\hline 6 & 1 and 4 and 5 & 12 \\
\hline
\end{tabular}




\section{NIH RePORTer}

Additionally, because both health IT is rapidly expanding and opioids have been a focus of research funding, we also searched NIH RePORTer using advanced search using the terms: medication-assisted treatment" and mobile or telehealth, "Medication-assisted treatment" and opioid and retention, Medication-assisted treatment and opioids and smart phone, "medicationassisted therapy" and opioid and mhealth, "MAT" and opioid and mhealth, "MAT" and opioid and smart phone, and we searched NIH RePORTer Matchmaker using the following terms: opioid, medication-assisted treatment, MAT, medications for addiction treatment, Medicationassisted therapy, opioid, opioids, opioid use disorder, retention, retention, retention, smart phone, smartphone, app, telehealth, Mhealth, mhealth, mobile, IT, retention, retention on June 12,2019.

\section{Google Play Store}

A search of the Google Play store on May 18, 2019 searched the key terms "Opioid Use Disorder" "Medication Assisted Treatment" "Methadone" "Buprenorphine" and/or "Suboxone" to identify potential mobile applications (apps) aimed at increasing retention in MAT. To be included, the Google Play store app description needed to mention retention, be specific to OUD and MAT, and include some sort of interactive program (not be strictly informational). Descriptions of apps in the Google Play store were analyzed to determine key features of apps. 


\section{Appendix B. Data Tables}

Table 1. Published literature on care settings, services, and logistical support

\begin{tabular}{|c|c|c|c|c|c|c|c|}
\hline Topic & $\begin{array}{l}\text { Author, } \\
\text { Year, } \\
\text { Study } \\
\text { Design } \\
\text { Country }\end{array}$ & $\begin{array}{l}\text { Number of } \\
\text { Participants } \\
\text { Participant } \\
\text { Characteristics }\end{array}$ & $\begin{array}{c}\text { MAT } \\
\text { Medications }\end{array}$ & $\begin{array}{l}\text { Timing \& } \\
\text { Outcome }\end{array}$ & Interventions & Results & $\begin{array}{l}\text { Quality } \\
\text { Rating }\end{array}$ \\
\hline \multirow[t]{2}{*}{\begin{tabular}{|l} 
Pre-release \\
MAT settings
\end{tabular}} & $\begin{array}{l}\text { Hedrich, } \\
2012,{ }^{1} \\
\text { SR }\end{array}$ & 27 articles & $\begin{array}{l}\text { Methadone, } \\
\text { buprenorphine } \\
\text { and } \\
\text { methadone, } \\
\text { buprenorphine- } \\
\text { naloxone, levo- } \\
\text { alpha acetyl } \\
\text { methadol } \\
\text { (LAAM) }\end{array}$ & $\begin{array}{l}6 \text { months after } \\
\text { release } \\
\text { Retention: \% } \\
\text { participants } \\
\text { remaining in } \\
\text { MAT }\end{array}$ & $\begin{array}{l}\text { Intervention: MAT in } \\
\text { prison } \\
\text { vs } \\
\text { Control: No MAT in prison }\end{array}$ & $\begin{array}{l}\text { KQ1: More than } 50 \% \text { [range } 27- \\
75 \% \text { ] retained in intervention } \\
\text { group vs fewer than } 5 \% \text { [range } \\
\text { 0-9\%] retained in control group } \\
\text { KQ2: Not reported } \\
\text { KQ3: Not reported }\end{array}$ & Good \\
\hline & $\begin{array}{l}\text { Friedmann, } \\
2018^{2} \\
\text { RCT } \\
\text { USA }\end{array}$ & $\begin{array}{l}15 \\
\text { Pre-release v } \\
\text { Post-release } \\
\mathrm{n}=9 \text { vs } 5 \\
\text { Mean Age= } 38.9 \\
\text { vs } 33.6 \\
\text { Gender: } 7 \% \\
\text { female } \\
\text { Race/Ethnicity: } \\
17 \% \text { non-White } \\
\text { Years education: } \\
11.6 \text { vs } 11.0 \\
\text { Employed: } 14.1 \\
\text { vs } 33.3 \\
\text { ASI drug risk: } 1.9 \\
\text { vs } 1.0\end{array}$ & $\begin{array}{l}\text { Naltrexone (XR } \\
\text { and injection) }\end{array}$ & $\begin{array}{l}6 \text { months } \\
\text { Retention: } \\
\text { 1. Injections } \\
\text { received } \\
\text { 2. Percentage } \\
\text { who received } \\
\text { all } 6 \text { monthly } \\
\text { injections } \\
\text { 3. Treatment } \\
\text { appointments } \\
\text { attended }\end{array}$ & $\begin{array}{l}\text { Pre-release intervention: } \\
\text { Participants received } 1 \\
\text { XR-naltrexone injection 1- } \\
2 \text { weeks prior to release } \\
\text { from prison plus up to } 5 \\
\text { monthly injections in } \\
\text { community } \\
\text { vs } \\
\text { Post-release: No pre- } \\
\text { release injection. Up to } 6 \\
\text { post-release injections in } \\
\text { community }\end{array}$ & $\begin{array}{l}\text { KQ1: Mean (SD) number of } \\
\text { injections received ( } p \text {-values not } \\
\text { reported): } 2.8(1.9) \text { pre-release } \\
\text { vs 1.3(1.9) post-release } \\
\text { Received all } 6 \text { injections: } 2 / 9 \\
(22 \%) \text { in pre-release group vs } \\
\text { 0/6 (0\%) in post-release group } \\
\text { Treatment appointments } \\
\text { attended: } 46 \% \text { pre-release } \\
\text { group vs } 22 \% \text { post-release } \\
\text { group } \\
\text { KQ2: Not reported } \\
\text { KQ3: Not reported }\end{array}$ & Poor \\
\hline
\end{tabular}




\begin{tabular}{|c|c|c|c|c|c|c|c|}
\hline Topic & $\begin{array}{l}\text { Author, } \\
\text { Year, } \\
\text { Study } \\
\text { Design } \\
\text { Country }\end{array}$ & $\begin{array}{l}\text { Number of } \\
\text { Participants } \\
\text { Participant } \\
\text { Characteristics }\end{array}$ & $\begin{array}{c}\text { MAT } \\
\text { Medications }\end{array}$ & $\begin{array}{l}\text { Timing \& } \\
\text { Outcome }\end{array}$ & Interventions & Results & $\begin{array}{l}\text { Quality } \\
\text { Rating }\end{array}$ \\
\hline \begin{tabular}{|l} 
Pre-release \\
MAT settings
\end{tabular} & $\begin{array}{l}\text { Gordon, } \\
2017^{3} \\
2 \times 2 \\
\text { factorial } \\
\text { design RCT } \\
\text { USA }\end{array}$ & $\begin{array}{l}213 \\
\text { Mean Age: } \\
39.08(8.8) \text { years } \\
\text { Gender: } 29.9 \% \\
\text { female } \\
\text { Race/Ethnicity: } \\
70.1 \% \text { African } \\
\text { American; } \\
25.6 \% \text { White } \\
\text { Prior drug } \\
\text { treatment: } 81.9 \% \\
\text { Prior } \\
\text { buprenorphine } \\
\text { treatment: } 15.2 \% \\
\text { \# heroin use } \\
\text { days prior to } \\
\text { incarceration: } \\
\text { 24.45(10.1) }\end{array}$ & Buprenorphine & $\begin{array}{l}12 \text { months } \\
\text { Retention: } \\
\text { Days in } \\
\text { treatment } \\
\text { program post- } \\
\text { release up to } \\
12 \text { months }\end{array}$ & $\begin{array}{l}2 \text { (Pre-release Treatment } \\
\text { Condition: Buprenorphine } \\
\text { Treatment Vs. Counseling } \\
\text { Only) x } 2 \text { (Post-Release } \\
\text { Service Setting: OTP vs. } \\
\text { CHC) } \\
\text { Buprenorphine began } \\
\text { either (1) in prison and } \\
\text { continue care in an OTP } \\
\text { or in (2) an outpatient } \\
\text { substance abuse program } \\
\text { within a CHC; or to begin } \\
\text { buprenorphine after } \\
\text { release from prison (3) in } \\
\text { an OTP or (4) in the CHC } \\
\text { Post-release: titrated dose } \\
\text { to } 8 \text { mg/day, then } 16 \text { mg } \\
3 x / \text { week. }\end{array}$ & $\begin{array}{l}\text { KQ1: Mean (SE) number of days } \\
\text { retained in treatment: } 65.9(12.2) \\
\text { pre-release vs } 21.8(7.6) \text { post- } \\
\text { release ( } p=0.005) \\
\text { KQ2: Not reported } \\
\text { KQ3: No differences in retention } \\
\text { outcomes by gender }\end{array}$ & Fair \\
\hline
\end{tabular}




\begin{tabular}{|c|c|c|c|c|c|c|c|}
\hline Topic & $\begin{array}{l}\text { Author, } \\
\text { Year, } \\
\text { Study } \\
\text { Design } \\
\text { Country }\end{array}$ & $\begin{array}{l}\text { Number of } \\
\text { Participants } \\
\text { Participant } \\
\text { Characteristics }\end{array}$ & $\begin{array}{c}\text { MAT } \\
\text { Medications }\end{array}$ & $\begin{array}{l}\text { Timing \& } \\
\text { Outcome }\end{array}$ & Interventions & Results & $\begin{array}{l}\text { Quality } \\
\text { Rating }\end{array}$ \\
\hline \multirow[t]{2}{*}{$\begin{array}{l}\text { Integrated } \\
\text { MAT into } \\
\text { Primary Care }\end{array}$} & $\begin{array}{l}\text { Brooner, } \\
2013^{4} \\
\text { RCT } \\
\text { USA }\end{array}$ & $\begin{array}{l}316 \\
\text { A vs B: } \\
n=160 \text { vs } 156 \\
\text { Mean Age: } \\
40.2(0.71) \text { vs } \\
39.4(0.68) \\
\text { Gender: } 62.5 \% \\
\text { vs } 62.2 \% \text { female } \\
\text { Race/Ethnicity: } \\
42.5 \% \text { vs } 40.4 \% \\
\text { minority race } \\
\text { Education: } 11.14 \\
\text { vs } 10.88 \\
\text { Employed: } \\
12.5 \% \text { vs } 16.7 \% \\
\text { Cocaine: } 31.9 \% \\
\text { vs } 26.3 \%\end{array}$ & Methadone & $\begin{array}{l}12 \text { months } \\
\text { Retention: } \\
\text { 1. \% } \\
\text { participants } \\
\text { remaining in } \\
\text { substance } \\
\text { abuse } \\
\text { treatment at } \\
12 \text { months } \\
\text { 2. Treatment } \\
\text { days over } 12 \\
\text { months }\end{array}$ & $\begin{array}{l}\text { On-site and integrated } \\
\text { substance abuse and } \\
\text { psychiatric care with } \\
\text { methadone } \\
\text { vs. } \\
\text { Off-site and non- } \\
\text { integrated substance } \\
\text { abuse and psychiatric } \\
\text { care. Traditional specialty } \\
\text { methadone outpatient } \\
\text { treatment program }\end{array}$ & $\begin{array}{l}\text { KQ1: Completed 12-month } \\
\text { substance abuse treatment: } \\
41.3 \% \text { on-site vs } 41.0 \% \text { off-site } \\
(p=0.96) \\
\text { Mean (SE) treatment days: } \\
226.0(10.8) \text { on-site vs } \\
228.7(10.7) \text { off-site }(p=0.89) \\
\text { KQ2: Not reported } \\
\text { KQ3: Not reported }\end{array}$ & Fair \\
\hline & $\begin{array}{l}\text { Carrieri, } \\
2014^{5} \\
\text { RCT } \\
\text { France }\end{array}$ & $\begin{array}{l}195 \\
\text { Primary care } \\
\text { (PC) vs } \\
\text { Specialized care } \\
\text { (SC): } \\
\text { n=147 vs } 48 \\
\text { Mean Age: } \\
32[27-38] \text { vs } \\
30[27-39] \\
\text { Gender: } 14 \% \text { vs } \\
21 \% \text { female }\end{array}$ & Methadone & $\begin{array}{l}12 \text { months } \\
\text { Retention: \% } \\
\text { participants } \\
\text { retained in } \\
\text { methadone } \\
\text { treatment }\end{array}$ & $\begin{array}{l}\text { Integration of methadone } \\
\text { into primary care (PC) } \\
\text { vs. } \\
\text { Methadone received in } \\
\text { specialty clinic setting } \\
\text { (SC) }\end{array}$ & $\begin{array}{l}\text { KQ1: Retention: } 33 / 48(69 \%) \text { in } \\
\text { SC vs } 129 / 147(88 \%) \text { in PC } \\
\text { were still in treatment. pLog } \\
\text { rank=0.13 (per protocol } \\
\text { analysis) } \\
\text { KQ2: Not reported } \\
\text { KQ3: Not reported }\end{array}$ & Fair \\
\hline
\end{tabular}




\begin{tabular}{|c|c|c|c|c|c|c|c|}
\hline Topic & $\begin{array}{l}\text { Author, } \\
\text { Year, } \\
\text { Study } \\
\text { Design } \\
\text { Country }\end{array}$ & $\begin{array}{l}\text { Number of } \\
\text { Participants } \\
\text { Participant } \\
\text { Characteristics }\end{array}$ & $\begin{array}{c}\text { MAT } \\
\text { Medications }\end{array}$ & $\begin{array}{l}\text { Timing \& } \\
\text { Outcome }\end{array}$ & Interventions & Results & \begin{tabular}{|l} 
Quality \\
Rating
\end{tabular} \\
\hline $\begin{array}{l}\text { Integrated } \\
\text { MAT into } \\
\text { Primary Care }\end{array}$ & $\begin{array}{l}\text { Miotto, } \\
2012^{6} \\
\text { RCT } \\
\text { USA }\end{array}$ & $\begin{array}{l}94 \\
\text { Opioid-treatment } \\
\text { program (OTP) } \\
\text { vs psychiatrist's } \\
\text { private practice } \\
\text { (PCS) vs } \\
\text { manualized } \\
\text { matrix model } \\
\text { (MMM): } \\
\text { Mean Age: } \\
34.51(10.47) \text { vs } \\
36.46(9.76) \text { vs } \\
35.24(9.88) \\
\text { Gender: } 32.14 \% \\
\text { vs } 48.48 \% \text { vs } \\
42.42 \% \text { female } \\
\text { Race/Ethnicity: } \\
42.86 \% \text { vs } \\
57.58 \% \text { vs } \\
69.70 \% \text { White } \\
\text { Unemployed: } \\
17.86 \% \text { vs } \\
21.21 \% \text { vs } \\
27.27 \%\end{array}$ & Buprenorphine & $\begin{array}{l}12 \text { months } \\
\text { Retention: } \\
\text { 1. Weeks } \\
\text { retained: } \\
\text { Number of } \\
\text { weeks } \\
\text { between } \\
\text { induction and } \\
\text { the last day } \\
\text { the participant } \\
\text { was assessed } \\
\text { during } \\
\text { treatment } \\
\text { period } \\
\text { 2. \% of group } \\
\text { who were } \\
\text { present at } \\
\text { week } 20\end{array}$ & $\begin{array}{l}\text { PCS: physician provided } \\
\text { supportive and } \\
\text { educational counseling } \\
\text { about drug abuse and } \\
\text { recovery; } \\
\text { vs } \\
\text { Behaviorally oriented } \\
\text { psychosocial treatment } \\
\text { (MMM) using matrix } \\
\text { recovery-relapse } \\
\text { prevention model } \\
\text { vs } \\
\text { Usual care: Outpatient } \\
\text { OTP }\end{array}$ & $\begin{array}{l}\text { KQ1: Mean number of weeks } \\
\text { retained: } 18.52(21.77) \text { PCS vs } \\
\text { 24.85(22.09) MMM vs } \\
\text { 13.96(14.96) OTP ( } p=0.11) \\
\text { Present at week } 20: 33.3 \% \text { PCS } \\
\text { vs } 51.52 \% \text { MMM vs } 21.43 \% \\
\text { OTP ( } p=0.05) \\
\text { KQ2: Not reported } \\
\text { KQ3: Not reported }\end{array}$ & Fair \\
\hline
\end{tabular}




\begin{tabular}{|c|c|c|c|c|c|c|c|}
\hline Topic & $\begin{array}{l}\text { Author, } \\
\text { Year, } \\
\text { Study } \\
\text { Design } \\
\text { Country }\end{array}$ & $\begin{array}{l}\text { Number of } \\
\text { Participants } \\
\text { Participant } \\
\text { Characteristics }\end{array}$ & $\begin{array}{c}\text { MAT } \\
\text { Medications }\end{array}$ & $\begin{array}{l}\text { Timing \& } \\
\text { Outcome }\end{array}$ & Interventions & Results & $\begin{array}{l}\text { Quality } \\
\text { Rating }\end{array}$ \\
\hline \begin{tabular}{|l} 
MAT in \\
ED/Hospital \\
Settings
\end{tabular} & $\begin{array}{l}\text { Liebschutz, } \\
2014^{7} \\
\text { RCT } \\
\text { USA }\end{array}$ & $\begin{array}{l}139 \\
\text { Mean Age: } \\
\text { 40.5(11.8) } \\
\text { Gender: } 18.8 \% \\
\text { female } \\
\text { Race/Ethnicity: } \\
\text { 43.2\% Non- } \\
\text { Hispanic White } \\
\text { Mean Rate of } \\
\text { Opioid Use: } \\
\text { 20.8(9.7) days } \\
\text { Prior OAT } \\
\text { 57(41.0) }\end{array}$ & Buprenorphine & $\begin{array}{l}6 \text { month } \\
\text { outcomes } \\
\text { from } \\
\text { enrollment } \\
\text { assessed } \\
\text { Retention: } \\
1 . \\
\text { Engagement } \\
\text { in outpatient } \\
\text { buprenorphine } \\
\text { treatment at } 6 \\
\text { months } \\
\text { 2. Opioid } \\
\text { agonist } \\
\text { treatment } \\
\text { (OAT) days - } \\
\text { self-reported } \\
\text { in the 30 days } \\
\text { before 3-, 6- } \\
\text { month } \\
\text { interviews } \\
\text { using } \\
\text { standard 30- } \\
\text { day timeline } \\
\text { follow-back }\end{array}$ & $\begin{array}{l}\text { Linkage group: received } \\
12 \text { mg } \\
\text { buprenorphine/naloxone } \\
\text { on day } 2 \text { and } 16 \mathrm{mg} \text { on } \\
\text { day } 3 \text { and remainder of } \\
\text { hospitalization. Linked to } \\
\text { hospital associated } \\
\text { primary care } \\
\text { buprenorphine OAT with } \\
\text { initial intake within } 7 \text { days } \\
\text { of discharge } \\
\text { vs } \\
\text { Treatment as usual (TAU) }\end{array}$ & $\begin{array}{l}\text { KQ1: Engaged in OAT at } 6 \\
\text { months: } 12(16.7 \%) \text { linkage } \\
\text { group vs 2(3\%) TAU group } \\
\text { ( } p=0.007) \\
\text { Self-report days of OAT use per } \\
30 \text { follow-up days: } 16.4 \text { linkage } \\
\text { group vs } 6.4 \text { TAU group, } P<.01 \text {. } \\
\text { KQ2: Not reported } \\
\text { KQ3: Not reported }\end{array}$ & Fair \\
\hline
\end{tabular}




\begin{tabular}{|c|c|c|c|c|c|c|c|}
\hline Topic & $\begin{array}{l}\text { Author, } \\
\text { Year, } \\
\text { Study } \\
\text { Design } \\
\text { Country }\end{array}$ & $\begin{array}{l}\text { Number of } \\
\text { Participants } \\
\text { Participant } \\
\text { Characteristics }\end{array}$ & $\begin{array}{c}\text { MAT } \\
\text { Medications }\end{array}$ & $\begin{array}{l}\text { Timing \& } \\
\text { Outcome }\end{array}$ & Interventions & Results & \begin{tabular}{|l} 
Quality \\
Rating
\end{tabular} \\
\hline $\begin{array}{l}\text { MAT in } \\
\text { ED/Hospital } \\
\text { Settings }\end{array}$ & $\begin{array}{l}\text { D'Onofrio, } \\
2017^{8} \\
\text { RCT } \\
\text { USA }\end{array}$ & $\begin{array}{l}290 \\
\text { Mean Age: } 31.5 \\
\text { Gender: } 24.1 \% \\
\text { female } \\
\text { Race/Ethnicity: } \\
\text { 75.5\% White } \\
\text { Married: 11.0\% } \\
\text { Unemployed: } \\
22.4 \% \\
\text { Unstable } \\
\text { Housing: 8.3\% } \\
\text { Primary Opioid } \\
\text { Heroin: } 75.9 \%\end{array}$ & Buprenorphine & $\begin{array}{l}6 \text { months and } \\
12 \text { months } \\
\text { Retention: } \\
\text { self-reported } \\
\text { formal } \\
\text { engagement } \\
\text { in addiction } \\
\text { treatment } \\
\text { using } \\
\text { Treatment } \\
\text { Services } \\
\text { Review } \\
\text { instrument }\end{array}$ & $\begin{array}{l}\text { ED initiated } \\
\text { buprenorphine with } \\
\text { linkage to outpatient } \\
\text { primary care } \\
\text { vs } \\
\text { Referral (TAU) } \\
\text { vs } \\
\text { Brief Intervention of 10-15 } \\
\text { minute manual-driven } \\
\text { audio taped Brief } \\
\text { Negotiation Interview } \\
\text { conducted by study RA }\end{array}$ & $\begin{array}{l}\text { KQ1: 6-month retention: } 49 / 92 \\
\text { (53\%) 95\% Cl 43-64 vs B. } \\
42 / 70(60 \%) 95 \% \mathrm{Cl} 48-72 \text { vs } \\
\text { C. } 39 / 76(51 \%) 95 \% \mathrm{Cl} 40-63 \text {, } \\
\text { p=0.546 } \\
12 \text { months retention: A. } 42 / 86 \\
(49 \%) 95 \% \mathrm{Cl} 38-60 \text { vs B. } \\
36 / 73(49 \%) 95 \% \mathrm{Cl} 38-61 \text { vs. } \\
\text { C } 49 / 78(63 \%) 95 \% \mathrm{Cl} 52-74, \mathrm{p} \\
=0.136 \\
\text { KQ2: Not reported } \\
\text { KQ3: Not reported }\end{array}$ & Fair \\
\hline
\end{tabular}




\begin{tabular}{|c|c|c|c|c|c|c|c|}
\hline Topic & $\begin{array}{l}\text { Author, } \\
\text { Year, } \\
\text { Study } \\
\text { Design } \\
\text { Country }\end{array}$ & $\begin{array}{l}\text { Number of } \\
\text { Participants } \\
\text { Participant } \\
\text { Characteristics }\end{array}$ & $\begin{array}{c}\text { MAT } \\
\text { Medications }\end{array}$ & $\begin{array}{l}\text { Timing \& } \\
\text { Outcome }\end{array}$ & Interventions & Results & \begin{tabular}{|l|} 
Quality \\
Rating
\end{tabular} \\
\hline \begin{tabular}{|l|} 
Logistical \\
Support
\end{tabular} & $\begin{array}{l}\text { Schwartz, } \\
2017^{9} \\
\text { RCT } \\
\text { USA }\end{array}$ & $\begin{array}{l}300 \\
\text { Mean Age: } \\
\text { 42.7(10.1) } \\
\text { Gender: 41\% } \\
\text { female } \\
\text { Race/Ethnicity: } \\
\text { 42\% African } \\
\text { American; } \\
\text { 41\% White }\end{array}$ & Methadone & $\begin{array}{l}12 \text { months } \\
\text { Retention: } \\
\text { 1. Treatment } \\
\text { retention in } \\
\text { original OTP } \\
\text { at } 12 \text { months } \\
\text { 2. Enrollment } \\
\text { at any MAT } \\
\text { program at } 12 \\
\text { months } \\
\text { *Treatment } \\
\text { retention in } \\
\text { original OTP } \\
\text { was } \\
\text { measured } \\
\text { from program } \\
\text { records and in } \\
\text { any other } \\
\text { OTP or } \\
\text { buprenorphine } \\
\text { treatment } \\
\text { from self- } \\
\text { report }\end{array}$ & $\begin{array}{l}\text { Patient-centered } \\
\text { methadone treatment } \\
\text { (PCM): Encouraged but } \\
\text { not required to attend } \\
\text { individual/group } \\
\text { counseling. Counselors } \\
\text { served solely as } \\
\text { therapists. Modified clinic } \\
\text { rules. No administrative } \\
\text { discharge. } \\
\text { vs } \\
\text { Treatment as usual (TAU) }\end{array}$ & $\begin{array}{l}\text { KQ1: Retention at } 12 \text { months: } \\
\text { 48.6\% PCM group vs } 46.3 \% \\
\text { TAU group, OR=0.91(0.58,1.44) } \\
\text { Risk diff } 0.02(-0.09,0.14) p=0.69 \\
\% \text { enrolled in any OTP or } \\
\text { buprenorphine treatment at } 12 \\
\text { months: } 78.9 \% \text { PCM group vs } \\
76.7 \% \text { TAU group, OR= } \\
0.88(0.48,1.62), p=0.68 \\
\text { KQ2: } 4 \text { non-study related deaths } \\
\text { in TAU. } 2 \text { overdoses in TAU. } \\
\text { PCM had } 2 \text { non-study related } \\
\text { deaths, } 1 \text { from methadone } \\
\text { overdose; } 59 \text { non-study related } \\
\text { hospitalizations in TAU and } 67 \\
\text { in PCM. } \\
\text { KQ3: Not reported }\end{array}$ & Good \\
\hline
\end{tabular}




\begin{tabular}{|c|c|c|c|c|c|c|c|}
\hline Topic & $\begin{array}{l}\text { Author, } \\
\text { Year, } \\
\text { Study } \\
\text { Design } \\
\text { Country }\end{array}$ & $\begin{array}{l}\text { Number of } \\
\text { Participants } \\
\text { Participant } \\
\text { Characteristics }\end{array}$ & $\begin{array}{c}\text { MAT } \\
\text { Medications }\end{array}$ & $\begin{array}{l}\text { Timing \& } \\
\text { Outcome }\end{array}$ & Interventions & Results & \begin{tabular}{|l|} 
Quality \\
Rating
\end{tabular} \\
\hline \begin{tabular}{|l|} 
Logistical \\
Support
\end{tabular} & $\begin{array}{l}\text { Beattie, } \\
2016^{10} \\
\text { RCT } \\
\text { UK }\end{array}$ & $\begin{array}{l}100 \\
\text { Gender: } 16 \% \\
\text { female } \\
\text { Race/Ethnicity: } \\
93.4 \% \text { White; } \\
6.1 \% \\
\text { Caribbean/Asian/ } \\
\text { Other } \\
\text { Had GP: } 69 \% \\
\text { Prior Treatment } \\
\text { SUD: } 90 \% \\
\text { Current Mental } \\
\text { Health Care: } \\
\text { 12\% } \\
\text { Homeless: } 26 \%\end{array}$ & Methadone & $\begin{array}{l}3 \text { months } \\
\text { Retention: } \\
\text { Percentage of } \\
\text { patients on } \\
\text { opioid } \\
\text { substitution } \\
\text { treatment } \\
\text { (OST) at 3- } \\
\text { months after } \\
\text { randomization }\end{array}$ & $\begin{array}{l}\text { Treatment intervention at } \\
\text { a syringe exchange } \\
\text { program (SEP) } \\
\text { Intervention group: Script } \\
\text { in a day" Offers immediate } \\
\text { access to OST through } \\
\text { referral to local specialist } \\
\text { primary care center. Peer } \\
\text { support volunteer } \\
\text { accompanied participant } \\
\text { to office, initiated on } 30-40 \\
\text { mL methadone, and script } \\
\text { for } 6 \text { days for } 21 \text { days, } \\
\text { then transfer to GP } \\
\text { practice } \\
\text { vs } \\
\text { Treatment as usual (TAU) }\end{array}$ & $\begin{array}{l}\text { KQ1: In OST at 3-months: 51\% } \\
\text { intervention group vs 47\% TAU } \\
\text { group (OR } 1.17 \text { 95\% Cl 0.54- } \\
\text { 2.57) } \\
\text { KQ2: Not reported } \\
\text { KQ3: Not reported }\end{array}$ & Fair \\
\hline
\end{tabular}




\begin{tabular}{|c|c|c|c|c|c|c|c|}
\hline Topic & $\begin{array}{l}\text { Author, } \\
\text { Year, } \\
\text { Study } \\
\text { Design } \\
\text { Country }\end{array}$ & $\begin{array}{l}\text { Number of } \\
\text { Participants } \\
\text { Participant } \\
\text { Characteristics }\end{array}$ & $\begin{array}{c}\text { MAT } \\
\text { Medications }\end{array}$ & $\begin{array}{l}\text { Timing \& } \\
\text { Outcome }\end{array}$ & Interventions & Results & \begin{tabular}{|l|} 
Quality \\
Rating
\end{tabular} \\
\hline $\begin{array}{l}\text { Logistical } \\
\text { Support }\end{array}$ & $\begin{array}{l}\text { Kidorf, } \\
2018^{11} \\
3 \text { arm RCT } \\
\text { USA }\end{array}$ & $\begin{array}{l}212 \\
\text { Standard care } \\
\text { intervention } \\
\text { (SCI) vs Voucher } \\
\text { reinforcement } \\
\text { intervention } \\
\text { (VRI) vs Low } \\
\text { threshold } \\
\text { intervention } \\
\text { (LTI): } \\
\text { Mean Age: } \\
40.3(10.9) \text { vs } \\
40.3(10.0) \text { vs } \\
38.8(9.4) \\
\text { Gender: } 54 \% \text { vs } \\
47 \% \text { vs } 65 \% \\
\text { male } \\
\text { Race/Ethnicity: } \\
34 \text { vs } 43 \text { vs } 36 \% \\
\text { White } \\
\text { Education: } \\
11.2(2.1) \text { vs } 11.5 \\
\text { (2.3) vs } 11.3 \\
\text { (2.0) } \\
\text { Employed: } 6 \% \\
\text { vs } 13 \% \text { vs } 6 \% \\
\text { HIV+: } 3 \% \text { vs } 6 \% \\
\text { vs } 9 \%\end{array}$ & Methadone & $\begin{array}{l}6 \text { months } \\
\text { Retention: \% } \\
\text { retained at } 90 \\
\text { days and } 180 \\
\text { days }\end{array}$ & $\begin{array}{l}\text { Treatment intervention at } \\
\text { a syringe exchange } \\
\text { program (SEP) } \\
\text { Voucher reinforcement } \\
\text { intervention (VRI): SCI } \\
\text { supplemented with } \\
\text { contingency management } \\
\text { - contingent on adherence } \\
\text { to daily schedules of } \\
\text { dosing and counseling. } \\
\text { One time per week based } \\
\text { on adherence the prior } \\
\text { week. Initial value } \$ 12 \text {, } \\
\text { maximum } \$ 174, \$ 30 \\
\text { bonus for } 3 \text { weeks of } \\
\text { adherence, earnings were } \\
\text { exchanged for } \\
\text { goods/services from local } \\
\text { community } \\
\text { vs } \\
\text { Low threshold intervention } \\
\text { (LTI): Participants } \\
\text { excluded from adaptive } \\
\text { treatment. Only required } \\
\text { to attend } 1 \text { counseling } \\
\text { session/month. } \\
\text { vs } \\
\text { Standard care intervention } \\
\text { (SCI): Routine program, } \\
\text { evidenced-based adaptive } \\
\text { treatment model }\end{array}$ & $\begin{array}{l}\text { KQ1: } 90 \text { day retention: } 34 \% \text { VRI } \\
\text { vs 35\% LTI vs 31\% SCI } \\
\text { ( } p=0.28) \\
180 \text { day retention: } 34 \% \text { VRI vs } \\
37 \% \text { LTI vs } 29 \% \text { SCI }(p=0.36) \\
\text { KQ2: Not reported } \\
\text { KQ3: Not reported }\end{array}$ & Fair \\
\hline
\end{tabular}




\begin{tabular}{|c|c|c|c|c|c|c|c|}
\hline Topic & $\begin{array}{l}\text { Author, } \\
\text { Year, } \\
\text { Study } \\
\text { Design } \\
\text { Country }\end{array}$ & $\begin{array}{l}\text { Number of } \\
\text { Participants } \\
\text { Participant } \\
\text { Characteristics }\end{array}$ & $\begin{array}{c}\text { MAT } \\
\text { Medications }\end{array}$ & $\begin{array}{l}\text { Timing \& } \\
\text { Outcome }\end{array}$ & Interventions & Results & $\begin{array}{l}\text { Quality } \\
\text { Rating }\end{array}$ \\
\hline \begin{tabular}{|l|} 
Logistical \\
Support
\end{tabular} & $\begin{array}{l}\text { Parpouchi, } \\
2018^{12} \\
\text { RCT } \\
\text { Canada }\end{array}$ & $\begin{array}{l}97 \\
\text { Mean Age: } \\
39.1(8.9) \\
\text { Gender: } 36.5 \% \\
\text { female } \\
\text { Race/Ethnicity: } \\
56.7 \% \text { White; } \\
20.6 \% \\
\text { Indigenous; } \\
22.7 \% \text { Other } \\
\text { Unemployed:94. } \\
\text { 8\% }\end{array}$ & Methadone & $\begin{array}{l}\text { Retention: } \\
\text { Medication } \\
\text { possession } \\
\text { ratio (MPR): } \\
\text { Proportion of } \\
\text { days during } \\
\text { an } \\
\text { observation } \\
\text { period for } \\
\text { which a } \\
\text { person has } \\
\text { been } \\
\text { dispensed } \\
\text { medication } \\
\text { between } \\
\text { randomization } \\
\text { and end of } \\
\text { study period } \\
\text { (March 31, } \\
\text { 2013) or date } \\
\text { of death. }\end{array}$ & $\begin{array}{l}\text { Housing first (HF) model: } \\
3 \text { interventions:1) market } \\
\text { rental apartments with } \\
\text { associated assertive } \\
\text { community treatment } \\
\text { (ACT) teams; 2) market } \\
\text { rental + intensive case } \\
\text { management; 3) } \\
\text { dedicated building with } \\
\text { integrated health and } \\
\text { social service providers } \\
\text { on-site. } \\
\text { vs } \\
\text { Treatment as usual (TAU) } \\
\text { referral to housing }\end{array}$ & $\begin{array}{l}\text { KQ1: Mean MPR: } 0.52 \mathrm{HF} \text { group } \\
\text { vs 0.57 TAU group }(\mathrm{p}=0.559) \\
\text { KQ2: Not reported } \\
\text { KQ3: Not reported }\end{array}$ & Fair \\
\hline
\end{tabular}

MAT= medications for addiction treatment; $\mathrm{SR}=$ systematic review; RCT= randomized controlled trial; n=number of participants; LAAM= levo-alpha acetyl methadol; KQ= key question; $\mathrm{XR}=$ extended-release; $\mathrm{NTX}=$ naltrexone; $\mathrm{SD}=$ standard deviation; $\mathrm{OTP}=$ opioid treatment program; $\mathrm{CHC}=$ community health center; $\mathrm{SE}=$ standard error; $\mathrm{PC}=$ primary care; $\mathrm{SC}=$ specialized care; $\mathrm{PCS}=$ psychiatrist's private practice; $\mathrm{MMM}=$ manualized matrix model; OAT= opioid agonist treatment; TAU= treatment as usual; ED= emergency department; PCM= patient-centered methadone treatment; OST= opioid substitution treatment; SEP= syringe exchange program; $\mathrm{SCI}=$ standard care intervention; VRI= voucher reinforcement intervention; LTI= low threshold intervention; MPR= medication possession ratio; HF= housing first; ACT= assertive community treatment 


\begin{tabular}{|c|c|c|c|c|c|c|}
\hline $\begin{array}{l}\text { Author, Year } \\
\text { Study Design } \\
\text { Country }\end{array}$ & $\begin{array}{l}\text { Number of } \\
\text { Participants } \\
\text { Participant } \\
\text { Characteristics }\end{array}$ & $\begin{array}{l}\text { MAT } \\
\text { Medications }\end{array}$ & Timing \& Outcome & Intervention & Results & $\begin{array}{l}\text { Quality } \\
\text { Rating }\end{array}$ \\
\hline $\begin{array}{l}\text { Amato, } \\
2011^{13} \\
\text { SR }\end{array}$ & 4319 & $\begin{array}{l}\text { Methadone } \\
\text { Buprenorphine } \\
\text { Levo-alpha } \\
\text { acetyl } \\
\text { methadol } \\
\text { (LAAM) }\end{array}$ & $\begin{array}{l}\text { Timing variable (6 - } 48 \\
\text { weeks) } \\
\text { Retention: \# participants in } \\
\text { treatment at the end of the } \\
\text { study }\end{array}$ & $\begin{array}{l}\text { Any psychosocial / } \\
\text { behavioral + any agonist } \\
\text { maintenance treatment } \\
\text { vs } \\
\text { Standard agonist treatment }\end{array}$ & $\begin{array}{l}\text { KQ1: Results do not show } \\
\text { benefit for retention in } \\
\text { treatment ( } 26 \text { studies, } 2582 \\
\text { participants) } \\
\text { KQ2: Not reported } \\
\text { KQ3: Not reported }\end{array}$ & Good \\
\hline $\begin{array}{l}\text { DeFulio, } \\
2012^{14} \\
\text { RCT } \\
\text { USA }\end{array}$ & $\begin{array}{l}38 \\
\text { Contingency group: } \\
\text { Gender: } 58 \% \text { female } \\
\text { Race/Ethnicity: } 84 \% \\
\text { African American } \\
\text { Unemployed over past } \\
3 \text { years: } 74 \% \\
\text { Control group: } \\
\text { Gender: } 26 \% \text { female } \\
\text { Race/Ethnicity: } 95 \% \\
\text { White } \\
\text { Unemployed over past } \\
3 \text { years: } 58 \%\end{array}$ & $\begin{array}{l}\text { Naltrexone } \\
\text { injections }\end{array}$ & $\begin{array}{l}6 \text { months } \\
\text { Retention: \% of participants } \\
\text { who completed entire } \\
\text { course of naltrexone } \\
\text { injections }\end{array}$ & $\begin{array}{l}\text { CM: Access to therapeutic } \\
\text { workplace contingent upon } \\
\text { acceptance of naltrexone } \\
\text { injection } \\
\text { vs } \\
\text { Prescription: Access to } \\
\text { therapeutic workplace } \\
\text { noncontingent upon } \\
\text { acceptance of naltrexone } \\
\text { injection }\end{array}$ & $\begin{array}{l}\text { KQ1: } 74 \% \text { CM group vs } \\
\text { 25\% prescription group, } \\
\text { X2 (1) = 8.53, } p=.004 \\
\text { KQ2: Not reported } \\
\text { KQ3: Not reported }\end{array}$ & Fair \\
\hline
\end{tabular}




\begin{tabular}{|c|c|c|c|c|c|c|}
\hline $\begin{array}{l}\text { Author, Year } \\
\text { Study Design } \\
\text { Country }\end{array}$ & $\begin{array}{l}\text { Number of } \\
\text { Participants } \\
\text { Participant } \\
\text { Characteristics }\end{array}$ & $\begin{array}{l}\text { MAT } \\
\text { Medications }\end{array}$ & Timing \& Outcome & Intervention & Results & $\begin{array}{l}\text { Quality } \\
\text { Rating }\end{array}$ \\
\hline $\begin{array}{l}\text { Dunn, } \\
2013^{15} \\
\text { RCT } \\
\& \\
\text { Dunn, } \\
2015^{16} \\
\text { RCT } \\
\text { USA }\end{array}$ & $\begin{array}{l}67 \\
\text { Mean Age: } 45 \\
\text { Gender: } 39 \% \text { female } \\
\text { Race/Ethnicity: } 86 \% \\
\text { African American }\end{array}$ & $\begin{array}{l}\text { Oral } \\
\text { naltrexone }\end{array}$ & $\begin{array}{l}\text { Retention: } \\
\text { 1. \% of participants who } \\
\text { completed course of } \\
\text { medication. } 26 \text { weeks. } \\
\text { 2. \% of participants who } \\
\text { had naltrexone-positive } \\
\text { urine screens at } 100 \% \text { of } \\
\text { 30-day check-points. } \\
\text { 3. Self-reported drug } \\
\text { treatment in } 30 \text { days before } \\
12 \text { month assessment }{ }^{16}\end{array}$ & 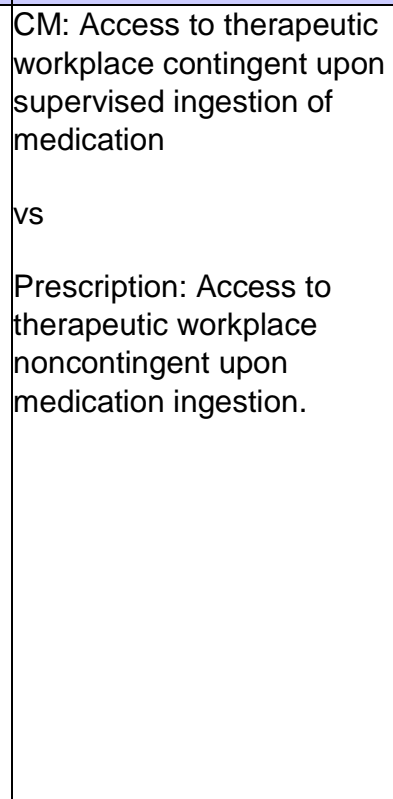 & $\begin{array}{l}\text { KQ1: Completed course of } \\
\text { medication: } 54 \% \text { CM group } \\
\text { vs } 16 \% \text { prescription group } \\
\text { ( } p<0.01) \\
\text { Naltrexone-positive urine } \\
\text { screens at } 100 \% \text { of } 30 \text {-day } \\
\text { check-points: } 43 \% \mathrm{CM} \\
\text { group vs } 3 \% \text { prescription } \\
\text { group ( } p<0.01) \\
\text { Drug treatment at } 12 \\
\text { months: } 17 \% \mathrm{CM} \text { group vs } \\
23 \% \text { prescription group } \\
\text { ( } p=0.45) \\
\text { KQ2: } 1 / 67 \text { deaths in } \\
\text { contingency, } 1 \text { month after } \\
\text { study } \\
\text { KQ3: Not reported }\end{array}$ & Fair \\
\hline
\end{tabular}




\begin{tabular}{|c|c|c|c|c|c|c|}
\hline $\begin{array}{l}\text { Author, Year } \\
\text { Study Design } \\
\text { Country }\end{array}$ & $\begin{array}{l}\text { Number of } \\
\text { Participants } \\
\text { Participant } \\
\text { Characteristics }\end{array}$ & $\begin{array}{l}\text { MAT } \\
\text { Medications }\end{array}$ & Timing \& Outcome & Intervention & Results & $\begin{array}{l}\text { Quality } \\
\text { Rating }\end{array}$ \\
\hline $\begin{array}{l}\text { Epstein, } \\
2009^{17} \\
\text { RCT } \\
\text { USA }\end{array}$ & $\begin{array}{l}252 \\
\text { Gender: 52\% female } \\
\text { Race/Ethnicity: } 66 \% \\
\text { African American } \\
\text { Unemployed: } 18 \%\end{array}$ & Methadone & $\begin{array}{l}20 \text { weeks } \\
\text { Retention: \% of participants } \\
\text { retained in study through } \\
\text { study completion }\end{array}$ & $\begin{array}{l}\text { CM: Vouchers for goods } \\
\text { and services provided for } \\
\text { submitting opioid-negative } \\
\text { urine samples } \\
\text { vs } \\
\text { Non-CM: Vouchers } \\
\text { awarded independent of } \\
\text { urine screen results on a } \\
\text { schedule yoked to the } \\
\text { performance of another } \\
\text { participant }\end{array}$ & $\begin{array}{l}\text { KQ1: No group differences } \\
\text { in retention } \\
\begin{array}{l}\text { Log-rank } x 2=2.51, d f=2, \\
p=0.29\end{array} \\
\text { KQ2: Not reported } \\
\text { KQ3: Not reported }\end{array}$ & Good \\
\hline $\begin{array}{l}\text { Everly, } \\
2011^{18} \\
\text { RCT } \\
\text { USA }\end{array}$ & $\begin{array}{l}35 \\
\text { Mean Age: } 42.5 \% \\
\text { Contingency group: } \\
\text { Gender: } 42.5 \% \text { female } \\
\text { Control group: } \\
\text { Gender: } 53 \% \text { female }\end{array}$ & $\begin{array}{l}\text { Naltrexone } \\
\text { injections }\end{array}$ & $\begin{array}{l}26 \text { weeks } \\
\text { Retention: \% of participants } \\
\text { who accepted all } \\
\text { scheduled naltrexone } \\
\text { injections }\end{array}$ & $\begin{array}{l}\text { CM: Access to therapeutic } \\
\text { workplace contingent upon } \\
\text { acceptance of naltrexone } \\
\text { injections } \\
\text { vs } \\
\text { Prescription: Access to } \\
\text { therapeutic workplace not } \\
\text { contingent upon } \\
\text { acceptance of naltrexone } \\
\text { injections }\end{array}$ & $\begin{array}{l}\text { KQ1: Received all } \\
\text { injections: 66\% CM group } \\
\text { vs 35\% prescription group } \\
\text { X2 }(1)=4.94, p=0.026 ; \mathrm{HR} \\
=0.32 ; 95 \% \mathrm{Cl}=0.117 \text { - } \\
0.874 \\
\text { KQ2: Not reported } \\
\text { KQ3: Not reported }\end{array}$ & Fair \\
\hline
\end{tabular}




\begin{tabular}{|l|l|l|l|l|l|}
\hline $\begin{array}{l}\text { Author, Year } \\
\text { Study Design }\end{array}$ & $\begin{array}{l}\text { Number of } \\
\text { Participants } \\
\text { Participant } \\
\text { Characteristics }\end{array}$ & $\begin{array}{l}\text { MAT } \\
\text { Medications }\end{array}$ & Timing \& Outcome & Intervention & Quality \\
Rating
\end{tabular}




\begin{tabular}{|c|c|c|c|c|c|c|}
\hline $\begin{array}{l}\text { Kidorf, } \\
2018^{11} \\
\text { RCT } \\
\text { USA }\end{array}$ & $\begin{array}{l}212 \\
\text { (Standard care } \\
\text { intervention) vs } \\
\text { (Voucher } \\
\text { reinforcement } \\
\text { intervention) vs (Low } \\
\text { threshold intervention): } \\
\text { Mean Age: } 40.3(10.9) \\
\text { vs } 40.3(10.0) \text { vs } \\
38.8(9.4) \\
\text { Gender: } 54 \% \text { vs } 47 \% \\
\text { vs } 65 \% \text { male } \\
\text { Race/Ethnicity: } 34 \text { vs } \\
43 \text { vs } 36 \% \text { White } \\
\text { Education: } 11.2(2.1) \\
\text { vs } 11.5 \text { (2.3) vs } 11.3 \\
\text { (2.0) } \\
\text { Employed: } 6 \% \text { vs } 13 \% \\
\text { vs } 6 \% \\
\text { HIV+: } 3 \% \text { vs } 6 \% \text { vs } \\
9 \%\end{array}$ & Methadone & $\begin{array}{l}\text { 6-months } \\
\text { Retention: \% retained at } 90 \\
\text { days and } 180 \text { days }\end{array}$ & $\begin{array}{l}\text { Treatment intervention at a } \\
\text { syringe exchange program } \\
\text { (SEP) } \\
\text { Voucher reinforcement } \\
\text { intervention (VRI): SCI } \\
\text { supplemented with } \\
\text { contingency management - } \\
\text { contingent on adherence to } \\
\text { daily schedules of dosing } \\
\text { and counseling. One time } \\
\text { per week based on } \\
\text { adherence the prior week. } \\
\text { Initial value } \$ 12, \text { maximum } \\
\$ 174, \$ 30 \text { bonus for } 3 \\
\text { weeks of adherence, } \\
\text { earnings were exchanged } \\
\text { for goods/services from } \\
\text { local community } \\
\text { vs } \\
\text { Low threshold intervention } \\
\text { (LTI): Participants excluded } \\
\text { from adaptive treatment. } \\
\text { Only required to attend } 1 \\
\text { counseling session/month. } \\
\text { vs } \\
\text { Standard care intervention } \\
\text { (SCI): Routine program, } \\
\text { evidenced-based adaptive } \\
\text { treatment model }\end{array}$ & $\begin{array}{l}\text { KQ1: } 90 \text { day retention: } \\
34 \% \text { VRI vs 35\% LTI vs } \\
31 \% \text { SCI ( } p=0.28) \\
180 \text { day retention: } 34 \% \text { VRI } \\
\text { vs } 37 \% \text { LTI vs } 29 \% \text { SCI } \\
(p=0.36) \\
\text { KQ2: Not reported } \\
\text { KQ3: Not reported }\end{array}$ & $\mathrm{Fa}$ \\
\hline
\end{tabular}




\begin{tabular}{|c|c|c|c|c|c|c|}
\hline $\begin{array}{l}\text { Author, Year } \\
\text { Study Design } \\
\text { Country }\end{array}$ & $\begin{array}{l}\text { Number of } \\
\text { Participants } \\
\text { Participant } \\
\text { Characteristics }\end{array}$ & $\begin{array}{l}\text { MAT } \\
\text { Medications }\end{array}$ & Timing \& Outcome & Intervention & Results & $\begin{array}{l}\text { Quality } \\
\text { Rating }\end{array}$ \\
\hline $\begin{array}{l}\text { Specka, } \\
2013^{20} \\
\text { RCT } \\
\text { Germany }\end{array}$ & $\begin{array}{l}136 \\
\text { Gender: } 67 \% \text { male } \\
\text { Unemployed: } 72 \%\end{array}$ & $\begin{array}{l}\text { Methadone } \\
\text { Buprenorphine }\end{array}$ & $\begin{array}{l}26 \text { weeks } \\
\text { Retention: \% of participants } \\
\text { who completed the study }\end{array}$ & $\begin{array}{l}\text { CM: Received escalating } \\
\text { number of take-home } \\
\text { dosages of medication } \\
\text { contingent upon increasing } \\
\text { number of opioid-free urine } \\
\text { samples } \\
\text { vs } \\
\text { Treatment as usual (TAU): } \\
\text { Received } 4 \text { days of } \\
\text { medication dosages for } 12 \\
\text { consecutive opioid-free } \\
\text { weekly urine screens }\end{array}$ & $\begin{array}{l}\text { KQ1: 62.5\% CM group vs } \\
\text { 64.1\% TAU group }(p=0.85) \\
\text { KQ2: Not reported } \\
\text { KQ3: Not reported }\end{array}$ & Fair \\
\hline
\end{tabular}

management; SEP= syringe exchange program; SCI= standard care intervention; VRI= voucher reinforcement intervention; LTI= low threshold intervention; TAU= treatment as usual 
Table 3. Published literature on health IT for MAT

\begin{tabular}{|c|c|c|c|c|c|c|}
\hline $\begin{array}{l}\text { Author, Year } \\
\text { Study Design } \\
\text { Country }\end{array}$ & $\begin{array}{l}\text { Number of } \\
\text { Participants } \\
\text { Participant } \\
\text { Characteristics }\end{array}$ & $\begin{array}{c}\text { MAT } \\
\text { Medications }\end{array}$ & Timing \& Outcome & Interventions & Results & $\begin{array}{l}\text { Quality } \\
\text { Rating }\end{array}$ \\
\hline $\begin{array}{l}\text { Marsch, } 2014^{21} \\
\text { RCT } \\
\text { USA }\end{array}$ & $\begin{array}{l}160 \\
\text { Mean Age: } 40.7 \\
\text { Gender: } 25 \% \\
\text { female } \\
\text { Race/Ethnicity: } \\
27.4 \% \text { Hispanic } \\
\text { Married: } 9.4 \% \\
\text { Unemployed: } 46.8 \%\end{array}$ & Methadone & $\begin{array}{l}12 \text { months } \\
\text { Retention: \% retained in } \\
\text { treatment over duration of } \\
\text { treatment }\end{array}$ & $\begin{array}{l}\text { Computer-based } \\
\text { education \& support } \\
\text { Intervention: 50\%/50\% } \\
\text { in-person/Therapeutic } \\
\text { Education System (TES) } \\
\text { vs } \\
\text { Treatment as usual } \\
\text { (TAU): MAT + clinic } \\
\text { resources (In-person } \\
\text { counseling \& group } \\
\text { therapy) }\end{array}$ & $\begin{array}{l}\text { KQ1: Retention: 31/80 } \\
\text { (39\%) intervention group vs } \\
\text { 31/80 (39\%) TAU group } \\
\text { p=0.56, OR CI (0.5-1.2) } \\
\text { KQ2: Not reported } \\
\text { KQ3: Not reported }\end{array}$ & Fair \\
\hline $\begin{array}{l}\text { Moore, } 2018^{22} \\
\text { RCT } \\
\text { USA }\end{array}$ & $\begin{array}{l}82 \\
\text { Treatment arm } \\
(n=40): \\
\text { Mean Age: } 43.6 \\
\text { Gender: } 60 \% \text { male } \\
\text { Race/Ethnicity: } \\
65 \% \text { White } \\
\text { Married: } 60 \% \\
\text { Unemployed: } 63 \%\end{array}$ & Methadone & $\begin{array}{l}\text { 3-months } \\
\text { Retention: \% of days of } \\
\text { medication adherence }\end{array}$ & $\begin{array}{l}\text { Computer-based } \\
\text { education \& support } \\
\text { Intervention: Automated, } \\
\text { computer-based, } \\
\text { cognitive behavioral } \\
\text { therapy (CBT) interactive } \\
\text { voice response (IVR) } \\
\text { system } \\
\text { vs } \\
\text { TAU: Methadone + clinic } \\
\text { resources (In-person } \\
\text { counseling \& group } \\
\text { therapy) }\end{array}$ & $\begin{array}{l}\text { KQ1: 94\% } \\
\text { p=0.60 } \\
\text { (retention only reported for } \\
\text { entire study population, not } \\
\text { individual groups) } \\
\text { KQ2: } 12 \text { Adverse Events } \\
\text { not described (7 of } 40 \\
\text { [17\%] Intervention, } 5 \\
\text { Control of } 42 \text { [12\%]); } 1 \\
\text { Control removed from } \\
\text { study due to medical issues } \\
\text { KQ3: Not reported } \\
\text { Greater IVR use, more } \\
\text { days abstinent. } \\
\text { IVR group requested } \\
\text { continued access to IVR } \\
\text { post study. } \\
\text { Qualitative interviews } \\
\text { patients reported just } \\
\text { knowing resource was } \\
\text { available was beneficial. }\end{array}$ & Poor \\
\hline
\end{tabular}




\begin{tabular}{|c|c|c|c|c|c|c|}
\hline $\begin{array}{l}\text { Author, Year } \\
\text { Study Design } \\
\text { Country }\end{array}$ & $\begin{array}{l}\text { Number of } \\
\text { Participants } \\
\text { Participant } \\
\text { Characteristics }\end{array}$ & $\begin{array}{c}\text { MAT } \\
\text { Medications }\end{array}$ & Timing \& Outcome & Interventions & Results & $\begin{array}{l}\text { Quality } \\
\text { Rating }\end{array}$ \\
\hline $\begin{array}{l}\text { Ruetsch, } 2012^{23} \\
\text { RCT } \\
\text { USA }\end{array}$ & $\begin{array}{l}1426 \\
\text { Participant } \\
\text { characteristics not } \\
\text { reported }\end{array}$ & Buprenorphine & $\begin{array}{l}12 \text { months } \\
\text { Retention: Medication } \\
\text { taken at the prescribed } \\
\text { dose on at least } 80 \% \text { of } \\
\text { days ( } 22 / 28 \text { days) based } \\
\text { on participant self-report of } \\
\text { the previous } 28 \text { days }\end{array}$ & $\begin{array}{l}\text { Computer-based } \\
\text { education \& support } \\
\text { Intervention: } \\
\text { Here to Help: online } \\
\text { educational materials, } \\
\text { treatment calendar, peer } \\
\text { stories, telephone } \\
\text { coaching + MAT } \\
\text { vs } \\
\text { TAU: MAT + clinic } \\
\text { resources (In-person } \\
\text { counseling \& group } \\
\text { therapy) }\end{array}$ & $\begin{array}{l}\text { KQ1: 55\% intervention } \\
\text { group vs } 56.1 \% \text { TAU group } \\
\text { ( } p=\text { not reported) } \\
\text { KQ2: Not reported } \\
\text { KQ3: Not reported }\end{array}$ & Fair \\
\hline $\begin{array}{l}\text { Shi, 201924 } \\
\text { RCT } \\
\text { USA }\end{array}$ & $\begin{array}{l}20 \\
\text { Mean Age: 18+ } \\
\text { Gender: } \\
\text { Predominantly male } \\
\text { Race/Ethnicity: } \\
\text { Predominantly } \\
\text { White } \\
\text { Education: Most } \\
\text { completed high } \\
\text { school } \\
\text { Employment: "About } \\
\text { half" }\end{array}$ & Buprenorphine & $\begin{array}{l}\text { 3-months } \\
\text { Retention: Mean number of } \\
\text { days in 12-week protocol }\end{array}$ & $\begin{array}{l}\text { Computer-based } \\
\text { education \& support } \\
\text { Intervention: Web-based } \\
\text { CBT } \\
\text { vs } \\
\text { TAU: MAT + clinic } \\
\text { resources (In-person } \\
\text { counseling \& group } \\
\text { therapy) }\end{array}$ & $\begin{array}{l}\text { KQ1: Mean days in 12- } \\
\text { week protocol: } 83 \text { days } \\
\text { intervention group vs } 69 \\
\text { days TAU group ( } p=0.19 \text { ) } \\
\text { KQ2: Not reported } \\
\text { KQ3: Not reported }\end{array}$ & Fair \\
\hline
\end{tabular}




\begin{tabular}{|c|c|c|c|c|c|c|}
\hline $\begin{array}{l}\text { Author, Year } \\
\text { Study Design } \\
\text { Country }\end{array}$ & $\begin{array}{l}\text { Number of } \\
\text { Participants } \\
\text { Participant } \\
\text { Characteristics }\end{array}$ & $\begin{array}{c}\text { MAT } \\
\text { Medications }\end{array}$ & Timing \& Outcome & Interventions & Results & $\begin{array}{l}\text { Quality } \\
\text { Rating }\end{array}$ \\
\hline $\begin{array}{l}\text { Eibl, } 2017^{25} \\
\text { Retrospective } \\
\text { cohort } \\
\text { Entire Province } \\
\text { of Canada }\end{array}$ & 3733 & $\begin{array}{l}\text { Methadone, } \\
\text { Buprenorphine }\end{array}$ & $\begin{array}{l}\text { 12-months } \\
\text { Retention: At least 1- year } \\
\text { consecutive MAT }\end{array}$ & $\begin{array}{l}\text { Telehealth } \\
\text { Patients stratified by } \\
\text { primary treatment } \\
\text { modality: } \\
>75 \% \text { telehealth } \\
\text { vs. } \\
25-75 \% \text { mixed } \\
\text { vs. } \\
<25 \% \text { in-person }\end{array}$ & $\begin{array}{l}\text { KQ1: } \\
\text { 50\%; aOR } 1.27 \text { (1.14-1.41) } \\
\text { 47\% aOR 1.27 (1.08-1.47) } \\
\text { 39\% (reference) } \\
\text { KQ2: Not reported } \\
\text { KQ3: Receiving care in } \\
\text { Northern clinics was } \\
\text { positively associated with } \\
\text { retention. Significant } \\
\text { associations were also } \\
\text { detected for sex, clinic } \\
\text { region, age, and peak } \\
\text { methadone dose, but not } \\
\text { for clinic rurality. }\end{array}$ & Fair \\
\hline $\begin{array}{l}\text { Weintraub, } \\
2018^{26} \\
\text { Retrospective } \\
\text { chart review } \\
\text { USA }\end{array}$ & $\begin{array}{l}177 \\
\text { Mean Age: } 35.1 \\
\text { Gender: } 89 \% \text { male } \\
\text { Race/Ethnicity: } 82 \% \\
\text { White } \\
\text { Insurance: } 96 \% \\
\text { Medicaid } \\
\text { Self-reported } \\
\text { abstinence at initial } \\
\text { evaluation: } 72 \%\end{array}$ & Buprenorphine & $\begin{array}{l}\text { 3-months } \\
\text { Retention: \% retained in } \\
\text { treatment }\end{array}$ & $\begin{array}{l}\text { Telehealth } \\
\text { Telehealth (to patient), } \\
\text { teleconsult (to provider) } \\
\text { not specified; connection } \\
\text { of academic medical } \\
\text { center to rural treatment } \\
\text { center } \\
\text { Patients were detoxified } \\
\text { prior to study }\end{array}$ & $\begin{array}{l}\text { KQ1: } 57.4 \% \\
\text { KQ2: Not reported } \\
\text { KQ3: Not reported }\end{array}$ & Fair \\
\hline
\end{tabular}




\begin{tabular}{|c|c|c|c|c|c|c|}
\hline $\begin{array}{l}\text { Author, Year } \\
\text { Study Design } \\
\text { Country }\end{array}$ & $\begin{array}{l}\text { Number of } \\
\text { Participants } \\
\text { Participant } \\
\text { Characteristics }\end{array}$ & $\begin{array}{c}\text { MAT } \\
\text { Medications }\end{array}$ & Timing \& Outcome & Interventions & Results & $\begin{array}{l}\text { Quality } \\
\text { Rating }\end{array}$ \\
\hline $\begin{array}{l}\text { Zheng, } 2017^{27} \\
\text { Retrospective } \\
\text { chart review } \\
\text { USA }\end{array}$ & $\begin{array}{l}55^{\star} \\
\text { Mean Age: } 37.2 \text { and } \\
34.4 \\
\text { Race/Ethnicity: } \\
\text { mostly White } \\
\text { Unemployed: mostly } \\
\text { unemployed } \\
\text { *study n= 100, } 55 \\
\text { followed for } 12 \\
\text { months }\end{array}$ & Buprenorphine & $\begin{array}{l}12 \text { months } \\
\text { Retention: \% of patients in } \\
\text { program at } 12 \text { months }\end{array}$ & $\begin{array}{l}\text { Telehealth } \\
\text { Intervention: Telehealth } \\
\text { psychiatry } \\
\text { vs } \\
\text { In-person psychiatry }\end{array}$ & $\begin{array}{l}\text { KQ1: } \\
41.7 \% \\
35.5 \% \\
p=0.55 \\
\text { KQ2: Not reported } \\
\text { KQ3: Not reported }\end{array}$ & Fair \\
\hline
\end{tabular}

IT= informational technology; MAT= medications for addiction treatment; RCT= randomized controlled trial; TES= Therapeutic Education System; TAU= treatment as usual; $\mathrm{KQ}=$ key question; $\mathrm{CBT}=$ cognitive behavioral therapy; IVR= interactive voice response 
Table 4. Published literature on extended-release medication based treatments

\begin{tabular}{|c|c|c|c|c|c|c|}
\hline $\begin{array}{l}\text { Author, Year } \\
\text { Study Design } \\
\text { Country } \\
\text { Funder }\end{array}$ & $\begin{array}{c}\text { Number of participants } \\
\text { Participant } \\
\text { characteristics }\end{array}$ & MAT Medications & Timing \& Outcome & Interventions & Results & $\begin{array}{l}\text { Quality } \\
\text { Rating }\end{array}$ \\
\hline $\begin{array}{l}\text { Tanum, } 2017^{28} \\
\text { RCT } \\
\text { Norway }\end{array}$ & $\begin{array}{l}159 \\
\text { Mean Age: } 35.1 \\
\text { Gender: } 72.3 \% \text { male } \\
\text { Race/Ethnicity: } 89.2 \% \\
\text { White } \\
\text { IV drug users: } 85.5 \% \\
\text { Only participants who } \\
\text { successfully completed } \\
\text { medically supervised } \\
\text { withdrawal were } \\
\text { randomized into the } \\
\text { study }\end{array}$ & $\begin{array}{l}\text { XR NTX monthly } \\
\text { injection } \\
\text { Daily SL buprenorphine/ } \\
\text { naloxone }\end{array}$ & $\begin{array}{l}3 \text { months } \\
\text { Retention: number of } \\
\text { days until dropout from } \\
\text { study medication and by } \\
\text { the number of patients } \\
\text { completing the study at } \\
\text { week } 12 \text {. }\end{array}$ & $\begin{array}{l}\text { XR NTX monthly } \\
\text { injection } \\
\text { vs } \\
\text { Daily SL buprenorphine/ } \\
\text { naloxone }\end{array}$ & $\begin{array}{l}\text { KQ1: Retention, mean } \\
\text { (SD) time: } 69.3(25.9) \\
\text { XR NTX vs } 63.7(29.9) \\
\text { days daily buprenorphine } \\
\text { / naloxone. At } 12 \text { weeks } \\
66 \% \text { participants had } \\
\text { attended all scheduled } \\
\text { follow-up and taken their } \\
\text { medications as } \\
\text { prescribed. } \\
\text { KQ2: Serious adverse } \\
\text { events not different } \\
\text { between the two groups } \\
\text { (8.5\% vs } 4.2 \%, \text { p=0.33). } \\
\text { 10 participants ( } 4 \text { in the } \\
\text { XR NTX group and } 6 \text { in } \\
\text { the buprenorphine/ } \\
\text { naloxone group) exited } \\
\text { the study due to adverse } \\
\text { events: } \\
\text { KQ3: Not reported }\end{array}$ & Good \\
\hline
\end{tabular}




\begin{tabular}{|c|c|c|c|c|c|c|}
\hline $\begin{array}{l}\text { Author, Year } \\
\text { Study Design } \\
\text { Country } \\
\text { Funder }\end{array}$ & $\begin{array}{c}\text { Number of participants } \\
\text { Participant } \\
\text { characteristics }\end{array}$ & MAT Medications & Timing \& Outcome & Interventions & Results & $\begin{array}{l}\text { Quality } \\
\text { Rating }\end{array}$ \\
\hline $\begin{array}{l}\text { Lee, } 2018^{29} \\
\text { RCT } \\
\text { USA }\end{array}$ & $\begin{array}{l}570 \\
\text { Age: } 18+ \\
\text { Gender: } 70.5 \% \text { male } \\
\text { Race/Ethnicity: } 74 \% \\
\text { White } \\
\text { Heroin Users: } 81 \% \\
\text { Prescription Opioid } \\
\text { Users: } 15.5 \% \\
\text { Participants were } \\
\text { randomized into the } \\
\text { study either prior to or } \\
\text { following successful } \\
\text { completion of medically } \\
\text { supervised withdrawal }\end{array}$ & $\begin{array}{l}\text { XR NTX monthly } \\
\text { injection } \\
\text { Daily SL buprenorphine/ } \\
\text { naloxone }\end{array}$ & $\begin{array}{l}6 \text { months } \\
\text { Retention: \% study } \\
\text { participants who } \\
\text { completed } 6 \text { months of } \\
\text { the study }\end{array}$ & $\begin{array}{l}\text { XR NTX monthly } \\
\text { injection } \\
\text { vs } \\
\text { Daily SL buprenorphine/ } \\
\text { naloxone }\end{array}$ & $\begin{array}{l}\text { KQ1: Retention at } 6 \\
\text { months: } 96 / 283 \text { ( } 33.9 \%) \\
\text { XR NTX vs } 115 / 287 \\
\text { (40\%) daily } \\
\text { buprenorphine/ naloxone } \\
\text { ( } p \text { value not reported) } \\
\text { KQ2: serious adverse } \\
\text { events not different } \\
\text { between groups (14\% } \\
\text { and } 11 \%) .28 \text { overdose } \\
\text { events, } 18 \text { (64\%) in the } \\
\text { XR NTX group, including } \\
8 \text { among induction } \\
\text { failures and } 10 \text { among } \\
\text { those who received at } \\
\text { least a single XR NTX } \\
\text { injection. } 5 \text { overdoses } \\
\text { were fatal, including } 2 \text { in } \\
\text { the XR NTX group and } 3 \\
\text { in the daily } \\
\text { buprenorphine/naloxone } \\
\text { group. } \\
\text { KQ3: Not reported }\end{array}$ & Fair \\
\hline
\end{tabular}




\begin{tabular}{|c|c|c|c|c|c|c|}
\hline $\begin{array}{l}\text { Author, Year } \\
\text { Study Design } \\
\text { Country } \\
\text { Funder }\end{array}$ & $\begin{array}{c}\text { Number of participants } \\
\text { Participant } \\
\text { characteristics }\end{array}$ & MAT Medications & Timing \& Outcome & Interventions & Results & $\begin{array}{l}\text { Quality } \\
\text { Rating }\end{array}$ \\
\hline $\begin{array}{l}\text { Sullivan, } 2019^{30} \\
\text { RCT } \\
\text { USA } \\
\text { NIDA }\end{array}$ & $\begin{array}{l}60 \\
\text { Mean Age: } 39.5 \\
\text { Gender: } 83.3 \% \text { male } \\
\text { Race/Ethnicity: } 63.3 \% \\
\text { White } \\
\text { Heroin Users: } 26.7 \% \\
\text { Prescription Opioid } \\
\text { Users: } 85.0 \% \\
\\
\text { Participants were } \\
\text { randomized after } \\
\text { successfully completing } \\
\text { medically supervised } \\
\text { opioid withdrawal }\end{array}$ & $\begin{array}{l}\text { XR NTX monthly } \\
\text { injection } \\
\text { Daily naltrexone }\end{array}$ & $\begin{array}{l}6 \text { months } \\
\text { Retention: \% study } \\
\text { participants who } \\
\text { completed } 6 \text { months of } \\
\text { the study. }\end{array}$ & $\begin{array}{l}\text { XR NTX monthly } \\
\text { injection } \\
\text { vs } \\
\text { Daily naltrexone }\end{array}$ & $\begin{array}{l}\text { KQ1: Retention at } 6 \\
\text { months: } 57.1 \% \text { XR NTX } \\
\text { vs } 28.1 \% \text { daily } \\
\text { naltrexone (HR=2.18, } \\
95 \% \mathrm{Cl}=1.07,4.43) \\
\text { KQ2: } 9 \text { serious adverse } \\
\text { events, including } 5 \text { in the } \\
\text { XR NTX and } 3 \text { in the } \\
\text { daily naltrexone group. } 5 \\
\text { participants were from } \\
\text { the study which included } \\
1 \text { participant who } \\
\text { developed hives after an } \\
\text { XR NTX injection. } \\
\text { KQ3: Not reported }\end{array}$ & Fair \\
\hline $\begin{array}{l}\text { Rosenthal, } \\
2016^{34} \\
\text { RCT } \\
\text { USA } \\
\text { Braeburn } \\
\text { Pharmaceuticals }\end{array}$ & $\begin{array}{l}177 \\
\text { Age: } 18+ \\
\text { Gender: } 59.1 \% \text { male } \\
\text { Race/Ethnicity: } 94.9 \% \\
\text { White, } \\
\text { Heroin Users: } 21.0 \% \\
\text { Prescription Opioid } \\
\text { Users: } 74.4 \%\end{array}$ & $\begin{array}{l}\text { XR Buprenorphine 6- } \\
\text { month implant } \\
\text { Daily SL buprenorphine }\end{array}$ & $\begin{array}{l}6 \text { months } \\
\text { Retention: \% study } \\
\text { participants who } \\
\text { completed } 6 \text { months of } \\
\text { the study. }\end{array}$ & $\begin{array}{l}\text { Clinically stable on daily } \\
\text { buprenorphine for } 6 \\
\text { months before } \\
\text { enrollment: } \\
\text { XR Buprenorphine 6- } \\
\text { month implant } \\
\text { vs } \\
\text { Daily SL buprenorphine }\end{array}$ & $\begin{array}{l}\text { KQ1: Retention: } 81 / 87 \\
(93.1 \%) \text { implant vs } 84 / 90 \\
(94.3 \%) \text { daily } \\
\text { buprenorphine (p-value } \\
\text { not reported) } \\
\text { KQ2: } 5 \text { serious adverse } \\
\text { events reported, } 3 \text { in the } \\
\text { daily buprenorphine and } \\
2 \text { in the buprenorphine } \\
\text { implant group. } 1 \\
\text { participant in the } \\
\text { buprenorphine implant } \\
\text { exited the study. } \\
\text { KQ3: Not reported }\end{array}$ & Good \\
\hline
\end{tabular}




\begin{tabular}{|c|c|c|c|c|c|c|}
\hline $\begin{array}{l}\text { Author, Year } \\
\text { Study Design } \\
\text { Country } \\
\text { Funder }\end{array}$ & $\begin{array}{c}\text { Number of participants } \\
\text { Participant } \\
\text { characteristics }\end{array}$ & MAT Medications & Timing \& Outcome & Interventions & Results & $\begin{array}{l}\text { Quality } \\
\text { Rating }\end{array}$ \\
\hline $\begin{array}{l}\text { Lofwall, 2018 } \\
\text { RCT } \\
\text { USA } \\
\text { Braeburn } \\
\text { Pharmaceuticals } \\
\text { University of } \\
\text { Kentucky }\end{array}$ & $\begin{array}{l}428 \\
\text { Age: } 18+ \\
\text { Gender: } 61.4 \% \text { male } \\
\text { Race/Ethnicity: } 74.2 \% \\
\text { White } \\
\text { Heroin Users: } 70.8 \% \\
\text { Prescription Opioid } \\
\text { Users: } 29.2 \%\end{array}$ & $\begin{array}{l}\text { XR Buprenorphine } \\
\text { monthly injection } \\
\text { Daily SL buprenorphine } \\
\text { Inaloxone }\end{array}$ & $\begin{array}{l}24 \text { weeks } \\
\text { Retention: \% participants } \\
\text { retained on the study } \\
\text { medication regimen at } 24 \\
\text { weeks of treatment }\end{array}$ & $\begin{array}{l}\text { XR Buprenorphine } \\
\text { injections (weekly during } \\
\text { weeks } 1-11, \text { monthly } \\
\text { during weeks } 12-24 \text { ) + } \\
\text { daily SL placebo } \\
\text { vs } \\
\text { Placebo injections } \\
\text { (weekly during weeks 1- } \\
\text { 11, monthly during } \\
\text { weeks } 12-24 \text { ) + daily } \\
\text { SL buprenorphine/ } \\
\text { naloxone }\end{array}$ & $\begin{array}{l}\text { KQ1: Retention: } 56.8 \% \\
\text { XR buprenorphine vs } \\
58.1 \% \text { daily } \\
\text { buprenorphine/naloxone } \\
\text { (p-value not reported) } \\
\text { KQ2: } 18 \text { participants } \\
\text { reported at least } 1 \\
\text { serious non-fatal adverse } \\
\text { event; which lead to } \\
\text { study disenrollment } \\
\text { among } 3.3 \% \\
\text { buprenorphine injection } \\
\text { and 1.4\% daily } \\
\text { buprenorphine } \\
\text { participants. only } 1 \\
\text { serious adverse event } \\
\text { was related to the } \\
\text { buprenorphine injection. } \\
5 \text { daily buprenorphine/ } \\
\text { naloxone participants } \\
\text { reported nonfatal } \\
\text { overdoses. } \\
\text { KQ3: Not reported }\end{array}$ & Fair \\
\hline
\end{tabular}

MAT= medications for addiction treatment; RCT= randomized controlled trial; $\mathrm{IV}=$ intravenous; $\mathrm{XR}=$ extended-release; $\mathrm{NTX}=$ naltrexone; $\mathrm{SL}=$ sublingual; $\mathrm{KQ}=\mathrm{key}$ question; $\mathrm{CI}=$ confidence interval; KCL= King's College London; SLaM= South London and Maudsley; NHS= National Health Service 
Table 5. Published literature on psychosocial support interventions

\begin{tabular}{|c|c|c|c|c|c|c|}
\hline $\begin{array}{l}\text { Author, Year } \\
\text { Study Design } \\
\text { Country }\end{array}$ & $\begin{array}{l}\text { Number of participants } \\
\text { Participant } \\
\text { characteristics }\end{array}$ & MAT Medications & Timing \& Outcome & Interventions & Results & $\begin{array}{l}\text { Quality } \\
\text { Rating }\end{array}$ \\
\hline $\begin{array}{l}\text { Amato, } 2011^{13} \\
\text { SR }\end{array}$ & $\begin{array}{l}4319 \\
\text { Age: } 18+, \text { average } 35 \text {, } \\
\text { range: } 27-45 \text { years } \\
\text { Gender: } 73 \% \text { male } \\
\text { Non-pregnant } \\
\text { Naïve/stable in } \\
\text { treatment: varies at } \\
\text { individual study level }\end{array}$ & $\begin{array}{l}\text { Methadone } \\
\text { Buprenorphine } \\
\text { Levo-alpha acetyl } \\
\text { methadol (LAAM) }\end{array}$ & $\begin{array}{l}\text { Timing variable (6 - } \\
48 \text { weeks) } \\
\text { Retention: \# } \\
\text { participants in } \\
\text { treatment at the end } \\
\text { of the study }\end{array}$ & $\begin{array}{l}\text { Any psychosocial / } \\
\text { behavioral + any } \\
\text { agonist maintenance } \\
\text { treatment } \\
\text { vs } \\
\text { Standard agonist } \\
\text { treatment }\end{array}$ & $\begin{array}{l}\text { KQ1: Results do not } \\
\text { show benefit for } \\
\text { retention in treatment } \\
\text { (26 studies, } 2582 \\
\text { participants) } \\
\text { KQ2: Not reported } \\
\text { KQ3: Not reported }\end{array}$ & $\begin{array}{l}\text { Quality of } \\
\text { included } \\
\text { studies for } \\
\text { outcome } \\
\text { of } \\
\text { retention } \\
\text { assessed } \\
\text { as 'high' } \\
\text { using } \\
\text { GRADE }\end{array}$ \\
\hline $\begin{array}{l}\text { Christensen, } 2014^{36} \\
\text { RCT } \\
\text { USA }\end{array}$ & $\begin{array}{l}170 \\
\text { Mean Age: } 20-63 \\
\text { Non-pregnant } \\
\text { Not incarcerated } \\
\text { Naïve/stable in } \\
\text { treatment: naïve, but } \\
\text { unclear of if any patients } \\
\text { had previous MAT }\end{array}$ & $\begin{array}{l}\text { Buprenorphine } \\
\text { induction } \\
\text { Buprenorphine- } \\
\text { naloxone tablet } \\
\text { maintenance }\end{array}$ & $\begin{array}{l}\text { 3-months } \\
\text { Retention: \% } \\
\text { participants } \\
\text { completed all 3- } \\
\text { months }\end{array}$ & $\begin{array}{l}\text { Web-based } \\
\text { community } \\
\text { reinforcement } \\
\text { approach (CRA) + } \\
\text { contingency } \\
\text { management (CM) + } \\
\text { minimal therapist } \\
\text { counseling + MAT } \\
\text { vs } \\
\text { CM + minimal } \\
\text { therapist counseling } \\
+ \text { MAT }\end{array}$ & $\begin{array}{l}\text { KQ1: Retention: } 80 \% \\
\text { CRA+CM vs 64\% } \\
\text { CM+ counselling } \\
\text { OR }=2.30(1.15,4.60) \\
\text { KQ2: Not reported } \\
\text { KQ3: when stratified } \\
\text { by prior treatment the } \\
\text { hazard of dropping } \\
\text { out for CM-alone } \\
\text { participants was } 6.57 \\
\text { times }(X 2(1)=9.01 \text {, } \\
\text { p=0.003) that for } \\
\text { CRA+ participants. } \\
\text { For treatment-naive } \\
\text { participants, the } \\
\text { hazard for CM-alone } \\
\text { participants was } 1.15 \\
\text { times }(X 2(1)=0.13, \\
p=0.718) \text { that for } \\
\text { CRA+ participants }\end{array}$ & Poor \\
\hline
\end{tabular}




\begin{tabular}{|c|c|c|c|c|c|c|}
\hline $\begin{array}{l}\text { Author, Year } \\
\text { Study Design } \\
\text { Country }\end{array}$ & $\begin{array}{l}\text { Number of participants } \\
\text { Participant } \\
\text { characteristics }\end{array}$ & MAT Medications & Timing \& Outcome & Interventions & Results & $\begin{array}{l}\text { Quality } \\
\text { Rating }\end{array}$ \\
\hline $\begin{array}{l}\text { Fiellin, } 2013^{37} \\
\text { RCT } \\
\text { USA }\end{array}$ & $\begin{array}{l}141 \\
\text { Mean Age: } 33 \\
\text { Gender: }<70 \% \text { male } \\
\text { Race/Ethnicity: <80\% } \\
\text { White } \\
\text { Prescription drug use: } \\
36 \% \\
\text { Prior detox attempt: } \\
49 \%\end{array}$ & $\begin{array}{l}\text { Buprenorphine } \\
\text { Naloxone }\end{array}$ & $\begin{array}{l}6 \text { months } \\
\text { Retention: \% } \\
\text { participants } \\
\text { completed all } 6 \\
\text { months }\end{array}$ & $\begin{array}{l}\text { Physician } \\
\text { management }+ \\
\text { cognitive behavioral } \\
\text { therapy (CBT) } \\
\text { vs } \\
\text { Physician } \\
\text { management alone }\end{array}$ & $\begin{array}{l}\text { KQ1: Retention: } 39 \% \\
\text { CBT vs 45\% } \\
\text { physician } \\
\text { management alone } \\
(p=0.43) \\
\text { KQ2: Not reported } \\
\text { KQ3: Not reported }\end{array}$ & Good \\
\hline $\begin{array}{l}\text { Jaffray, } 2014^{38} \\
\text { RCT } \\
\text { Scotland }\end{array}$ & $\begin{array}{l}542 \\
\text { Mean Age: } 32 \\
\text { Gender: } 64 \% \text { male } \\
\text { Unemployed: } 91 \% \\
\text { Naïve/stable in } \\
\text { treatment: "initiated in } \\
\text { the last } 24 \text { months" - } \\
\text { stable }\end{array}$ & Methadone & $\begin{array}{l}6 \text { months in study; } \\
\text { baseline mean } 9 \\
\text { months in } \\
\text { methadone } \\
\text { Retention: \% } \\
\text { participants still } \\
\text { receiving treatment } \\
\text { at } 6 \text { months }\end{array}$ & $\begin{array}{l}\text { Motivational } \\
\text { interviewing + } \\
\text { resource pack (with } \\
\text { area-specific } \\
\text { information on } \\
\text { available services for } \\
\text { pharmacists) + } \\
\text { normal practice } \\
\text { methadone treatment } \\
\text { vs } \\
\text { Normal practice } \\
\text { methadone treatment }\end{array}$ & $\begin{array}{l}\text { KQ1: Retention: } \\
88 \% \text { intervention vs } \\
81 \% \text { usual care } \\
\text { (Adjusted } \\
\text { p=0.34) } \\
\text { OR = } 1.76(0.55, \\
5.64) \\
\text { KQ2: Physical and } \\
\text { psychological health } \\
\text { of the intervention } \\
\text { group significantly } \\
\text { deteriorated between } \\
\text { baseline and follow- } \\
\text { up, whilst the control } \\
\text { group remained } \\
\text { relatively unchanged } \\
\text { KQ3: Not reported }\end{array}$ & Poor \\
\hline
\end{tabular}




\begin{tabular}{|c|c|c|c|c|c|c|}
\hline $\begin{array}{l}\text { Author, Year } \\
\text { Study Design } \\
\text { Country }\end{array}$ & $\begin{array}{l}\text { Number of participants } \\
\text { Participant } \\
\text { characteristics }\end{array}$ & MAT Medications & Timing \& Outcome & Interventions & Results & $\begin{array}{l}\text { Quality } \\
\text { Rating }\end{array}$ \\
\hline $\begin{array}{l}\text { Marsden, } 2019^{39} \\
\text { RCT } \\
\text { UK }\end{array}$ & $\begin{array}{l}273 \\
\text { Age: } 18+ \\
\text { All participants were } \\
\text { treatment resistant (i.e., } \\
\text { had used illicit or non- } \\
\text { prescribed opioids or } \\
\text { cocaine on one or more } \\
\text { days in the past } 28 \text { days } \\
\text { at study screening, } \\
\text { which was verified by } \\
\text { positive urine drug } \\
\text { screen) }\end{array}$ & $\begin{array}{l}\text { Buprenorphine } \\
\text { Methadone }\end{array}$ & $\begin{array}{l}18 \text { weeks } \\
\text { Retention: \# days } \\
\text { from randomization } \\
\text { to the endpoint or } \\
\text { exit }\end{array}$ & $\begin{array}{l}\text { Personalized } \\
\text { psychosocial } \\
\text { intervention }+ \\
\text { treatment as usual } \\
\text { vs } \\
\text { Treatment as usual } \\
\text { (TAU) }\end{array}$ & $\begin{array}{l}\text { KQ1: No between- } \\
\text { group difference in } \\
\text { retention in either } \\
\text { unadjusted or } \\
\text { adjusted analyses. } \\
\text { KQ2: The number of } \\
\text { adverse events was } \\
\text { similar between } \\
\text { groups, and no } \\
\text { severe adverse } \\
\text { events in either group } \\
\text { were judged to be } \\
\text { treatment related. } \\
\text { KQ3: Not reported }\end{array}$ & Fair \\
\hline $\begin{array}{l}\text { Mitchell, } 2013^{40} \\
\text { RCT } \\
\text { USA }\end{array}$ & $\begin{array}{l}300 \\
\text { Age: 18+ } \\
\text { Race/Ethnicity: African } \\
\text { American population } \\
\text { Newly admitted to } \\
\text { buprenorphine treatment } \\
\text { at one of the } \\
\text { participating treatment } \\
\text { programs }\end{array}$ & Buprenorphine & $\begin{array}{l}6 \text { months } \\
\text { Retention: \% } \\
\text { participants in } \\
\text { buprenorphine } \\
\text { treatment at } 6 \\
\text { months }\end{array}$ & $\begin{array}{l}\text { Intensive outpatient } \\
\text { (IOP) } \\
\text { vs } \\
\text { Standard outpatient } \\
\text { (OP) }\end{array}$ & $\begin{array}{l}\text { KQ1: Retention: } \\
\text { 56.6\% IOP vs 58.7\% } \\
\text { OP } \\
\text { KQ2: Controlling for \# } \\
\text { of days in treatment, } \\
\text { greater counseling } \\
\text { exposure was } \\
\text { associated with } \\
\text { significantly less } \\
\text { improvement for } \\
\text { three outcomes: days } \\
\text { of heroin use, days of } \\
\text { cocaine use, and } \\
\text { days of criminal } \\
\text { activity (however } \\
\text { authors suggest the } \\
\text { association is not } \\
\text { causal) } \\
\text { KQ3: Not reported }\end{array}$ & Poor \\
\hline
\end{tabular}




\begin{tabular}{|c|c|c|c|c|c|c|}
\hline $\begin{array}{l}\text { Author, Year } \\
\text { Study Design } \\
\text { Country }\end{array}$ & $\begin{array}{l}\text { Number of participants } \\
\text { Participant } \\
\text { characteristics }\end{array}$ & MAT Medications & Timing \& Outcome & Interventions & Results & $\begin{array}{l}\text { Quality } \\
\text { Rating }\end{array}$ \\
\hline $\begin{array}{l}\text { Schwartz, 2012 } \\
\text { RCT } \\
\text { USA }\end{array}$ & $\begin{array}{l}230 \\
\text { Mean Age: } 43.2 \\
\text { Gender: } 70 \% \text { male } \\
\text { Race/Ethnicity: } 77.4 \% \\
\text { African American } \\
\text { Married: } 13.5 \% \\
\text { Employed During } 30 \\
\text { Days Prior to Baseline: } \\
32.6 \% \\
\text { Non-pregnant } \\
\text { Opioid dependent for } 1 \\
\text { year+ }\end{array}$ & Methadone & $\begin{array}{l}12 \text { months } \\
\text { Retention: \% } \\
\text { participants retained } \\
\text { in original MTP }\end{array}$ & $\begin{array}{l}\text { Interim methadone } \\
\text { (IM; supervised } \\
\text { methadone with } \\
\text { emergency } \\
\text { counseling only for } \\
\text { the first } 4 \text { months of } \\
\text { treatment) } \\
\text { vs } \\
\text { Restored methadone } \\
\text { (RM; routine } \\
\text { counseling with } \\
\text { smaller case loads } \\
\text { vs } \\
\text { Standard methadone } \\
\text { (SM; with routine } \\
\text { counseling) }\end{array}$ & $\begin{array}{l}\text { KQ1: Retention: } \\
60.6 \% \text { IM vs 37\% RM } \\
\text { vs 54.8\% SM } \\
\text { x2(2) }=4.8 \\
(p>0.05) \\
\text { KQ2: Not reported } \\
\text { KQ3: Not reported }\end{array}$ & Fair \\
\hline $\begin{array}{l}\text { Stein, 2015 } \\
\text { RCT } \\
\text { USA }\end{array}$ & $\begin{array}{l}9 \\
\text { Mean Age: } 41 \\
\text { Gender: } 65.3 \% \text { male } \\
\text { Race/Ethnicity: } 85.7 \% \\
\text { Non-Latino White } \\
\text { Reported they had ever } \\
\text { received prescribed } \\
\text { buprenorphine: } 28.6 \%\end{array}$ & $\begin{array}{l}\text { Buprenorphine- } \\
\text { naloxone induction } \\
\text { Buprenorphine } \\
\text { maintenance }\end{array}$ & $\begin{array}{l}\text { 3-months } \\
\text { Retention: \% } \\
\text { participants retained } \\
\text { in treatment }\end{array}$ & $\begin{array}{l}\text { DT (distress } \\
\text { tolerance) } \\
\text { intervention + } \\
\text { buprenorphine- } \\
\text { naloxone induction } \\
\text { then 3-months } \\
\text { buprenorphine } \\
\text { maintenance } \\
\text { vs } \\
\text { HE (health } \\
\text { education) control + } \\
\text { buprenorphine- } \\
\text { naloxone induction } \\
\text { then 3-months } \\
\text { buprenorphine } \\
\text { maintenance }\end{array}$ & $\begin{array}{l}\text { KQ1: Retention: } 75 \% \\
\text { DT vs 76\% control } \\
\text { Between group mean } \\
\text { difference }(95 \% \mathrm{Cl}) \\
-1.0(-25.1 ; 23.1) \\
\text { KQ2: Not reported } \\
\text { KQ3: Not reported }\end{array}$ & Good \\
\hline
\end{tabular}




\begin{tabular}{|c|c|c|c|c|c|c|}
\hline $\begin{array}{l}\text { Author, Year } \\
\text { Study Design } \\
\text { Country }\end{array}$ & $\begin{array}{l}\text { Number of participants } \\
\text { Participant } \\
\text { characteristics }\end{array}$ & MAT Medications & Timing \& Outcome & Interventions & Results & $\begin{array}{l}\text { Quality } \\
\text { Rating }\end{array}$ \\
\hline $\begin{array}{l}\text { Sullivan, } 2015 \\
\text { RCT } \\
\text { USA }\end{array}$ & $\begin{array}{l}125 \\
\text { Mean Age: } 38 \\
\text { Gender: } 21 \% \text { female } \\
\text { Race/Ethnicity: } 43 \% \\
\text { White } \\
\text { Heavy use (>6 bags } \\
\text { heroin/day): } 34 \%\end{array}$ & $\begin{array}{l}\text { XR Naltrexone } \\
\text { Oral Naltrexone }\end{array}$ & $\begin{array}{l}6 \text { months } \\
\text { Retention: \% of } \\
\text { participants retained } \\
\text { in treatment }\end{array}$ & $\begin{array}{l}\text { Behavioral } \\
\text { Naltrexone Therapy } \\
\text { (BNT) + standard } \\
\text { (oral and injectable } \\
\text { naltrexone) treatment } \\
\text { vs } \\
\text { Compliance } \\
\text { Enhancement (CE) + } \\
\text { standard (oral and } \\
\text { injectable naltrexone) } \\
\text { treatment } \\
\text { vs } \\
\text { Behavioral } \\
\text { Naltrexone Therapy } \\
\text { (BNT) + placebo } \\
\text { injection and oral } \\
\text { naltrexone } \\
\text { vs } \\
\text { Compliance } \\
\text { Enhancement (CE) + } \\
\text { placebo injection and } \\
\text { oral naltrexone }\end{array}$ & $\begin{array}{l}\text { KQ1: Retention: } \\
47.8 \% \text { BNT + } \\
\text { standard Naltrexone } \\
\text { vs } 16.7 \% \text { CE } \\
\text { +standard naltrexone } \\
\text { vs } 23.8 \% \text { BNT + } \\
\text { placebo vs } 14.3 \% \\
\text { CE+placebo } \\
\text { KQ2: Not reported } \\
\text { KQ3: For low-severity } \\
\text { opioid users, } \\
\text { retention was highest } \\
\text { (60\% at } 6 \text { months) in } \\
\text { Behavioral } \\
\text { Naltrexone Therapy } \\
\text { with a single } \\
\text { administration of } \\
\text { injection naltrexone } \\
\text { (XR-naltrexone) post- } \\
\text { detoxification. } \\
\text { For high-severity } \\
\text { opioid users, BNT- } \\
\text { XR-naltrexone + oral } \\
\text { naltrexone did not } \\
\text { perform as well. }\end{array}$ & Fair \\
\hline
\end{tabular}




\begin{tabular}{|c|c|c|c|c|c|c|}
\hline $\begin{array}{l}\text { Author, Year } \\
\text { Study Design } \\
\text { Country }\end{array}$ & $\begin{array}{l}\text { Number of participants } \\
\text { Participant } \\
\text { characteristics }\end{array}$ & MAT Medications & Timing \& Outcome & Interventions & Results & $\begin{array}{l}\text { Quality } \\
\text { Rating }\end{array}$ \\
\hline $\begin{array}{l}\text { Weiss, } 2011^{44} \\
\text { RCT } \\
\text { UK }\end{array}$ & $\begin{array}{l}653 \\
\text { Mean Age: } 32.9 \\
\text { Gender: } 38 \% \text { female } \\
\text { Race/Ethnicity: } 91.5 \% \\
\text { White } \\
\text { Unmarried: } 49.2 \% \\
\text { Employment: } 63.8 \% \\
\text { FTE } \\
\text { Met DSM IV criteria for } \\
\text { current opioid } \\
\text { dependence on } \\
\text { prescription opioids }\end{array}$ & $\begin{array}{l}\text { Buprenorphine- } \\
\text { naloxone }\end{array}$ & $\begin{array}{l}\text { Phase 1: } 4 \text { weeks (2 } \\
\text { week stabilization, } 2 \\
\text { week taper) } \\
\text { Retention: \# of SMM } \\
\text { (standard medical } \\
\text { management) visits } \\
\text { Phase } 2: 16 \text { weeks } \\
\text { (12 week treatment, } \\
4 \text { week taper) }\end{array}$ & $\begin{array}{l}\text { SMM + ODC (opioid } \\
\text { drug counseling) } \\
\text { vs } \\
\text { SMM alone }\end{array}$ & 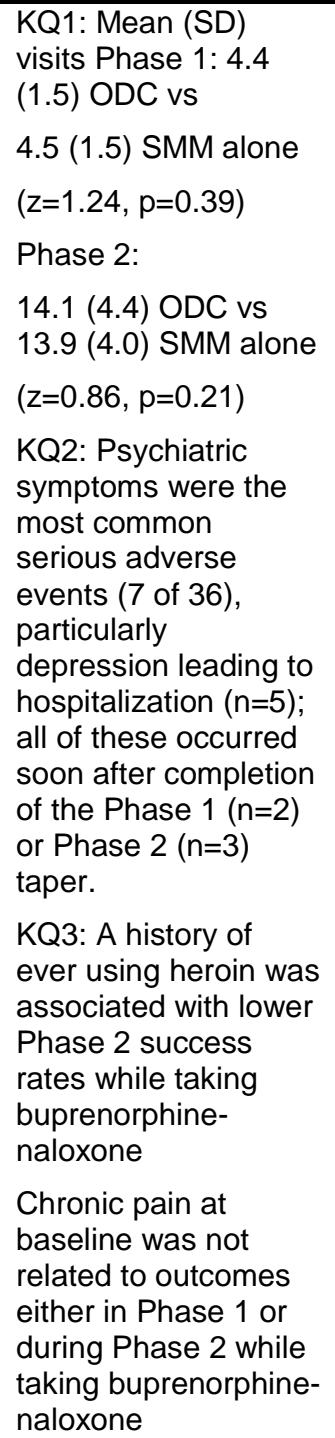 & Fair \\
\hline
\end{tabular}


MAT= medications for addiction treatment; $\mathrm{SR}=$ systematic review; LAAM= levo-alpha acetyl methadol; KQ= key question; GRADE= Grading of Recommendations Assessment, Development and Evaluation; RCT= randomized controlled trial; CRA= community reinforcement approach; $\mathrm{CM}=$ contingency management; $\mathrm{CBT}=$ cognitive behavioral therapy; TAU= treatment as usual; IOP= Intensive outpatient; OP= standard outpatient; MTP= methadone treatment program; IM= interim methadone; RM= restored methadone; $\mathrm{SM}$ = standard methadone; $\mathrm{DT}=$ distress tolerance; $\mathrm{HE}=$ health education; $\mathrm{XR}=$ extended-release; $\mathrm{BNT}=\mathrm{Behavioral}$ Naltrexone Therapy; $\mathrm{CE}=$ compliance enhancement; $\mathrm{SMM}=$ standard medical management; $\mathrm{ODC}=$ opioid drug counseling; $\mathrm{SD}=$ standard deviation 


\section{Appendix C. Quality Rating Tables}

Table 1. Quality ratings for care settings, services, logistical support

\begin{tabular}{|c|c|c|c|c|c|c|c|c|c|c|c|}
\hline Topic & $\begin{array}{l}\text { Author, } \\
\text { Year }\end{array}$ & Randomization & $\begin{array}{c}\text { Allocation } \\
\text { Concealment }\end{array}$ & $\begin{array}{l}\text { Groups } \\
\text { Similar } \\
\text { at } \\
\text { Baseline }\end{array}$ & $\begin{array}{c}\text { Blinded } \\
\text { Outcome } \\
\text { Assessors }\end{array}$ & $\begin{array}{l}\text { Blinded } \\
\text { Care } \\
\text { Provider }\end{array}$ & $\begin{array}{l}\text { Blinded } \\
\text { Patient }\end{array}$ & $\begin{array}{c}\text { Intention } \\
\text {-To-Treat } \\
\text { (ITT) } \\
\text { Analysis }\end{array}$ & $\begin{array}{l}\text { Acceptable } \\
\text { Levels of } \\
\text { Overall } \\
\text { Attrition }\end{array}$ & $\begin{array}{c}\text { Avoidance } \\
\text { of } \\
\text { Selective } \\
\text { Outcomes } \\
\text { Reporting }\end{array}$ & $\begin{array}{c}\text { Final } \\
\text { Quality } \\
\text { Rating }\end{array}$ \\
\hline \multirow{2}{*}{$\begin{array}{l}\text { Pre- } \\
\text { Release } \\
\text { MAT } \\
\text { Models }\end{array}$} & $\begin{array}{l}\text { Friedmann, } \\
2018^{2}\end{array}$ & Unclear & Unclear & Yes & No & No & No & Yes & Yes & No & Poor \\
\hline & $\begin{array}{l}\text { Gordon, } \\
2017^{3}\end{array}$ & Yes & Yes & Yes & Unclear & No & No & Yes & Yes & Yes & Fair \\
\hline \multirow{3}{*}{$\begin{array}{l}\text { MAT } \\
\text { Integrated } \\
\text { into } \\
\text { Primary } \\
\text { Care }\end{array}$} & $\begin{array}{l}\text { Brooner, } \\
2013^{4}\end{array}$ & Yes & Unclear & Yes & Unclear & No & No & Yes & Unclear & Yes & Fair \\
\hline & $\begin{array}{l}\text { Carrieri, } \\
2014^{5}\end{array}$ & Yes & Unclear & Yes & Unclear & No & No & Yes & Yes & Yes & Fair \\
\hline & $\begin{array}{l}\text { Miotto, } \\
2012^{6}\end{array}$ & Yes & Yes & No & No & No & No & Yes & Unclear & Yes & Fair \\
\hline \multirow{2}{*}{$\begin{array}{l}\text { MAT in EDI } \\
\text { Hospital } \\
\text { Settings }\end{array}$} & $\begin{array}{l}\text { Liebschutz, } \\
2014^{7}\end{array}$ & Yes & Unclear & Yes & No & No & No & Yes & Yes & Yes & Fair \\
\hline & D'Onofrio $^{8}$ & Yes & Yes & Yes & Unclear & No & No & No & Yes & Yes & Fair \\
\hline \multirow{4}{*}{$\begin{array}{l}\text { MAT in } \\
\text { Community } \\
\text { Settings/ } \\
\text { Social } \\
\text { Services }\end{array}$} & $\begin{array}{l}\text { Schwartz, } \\
2017^{9}\end{array}$ & Yes & Yes & Yes & No & No & No & No & Yes & Yes & Good \\
\hline & $\begin{array}{l}\text { Beattie, } \\
2016^{10}\end{array}$ & Yes & Yes & Yes & No & No & No & Yes & Yes & Yes & Fair \\
\hline & $\begin{array}{l}\text { Kidorf, } \\
2018^{11}\end{array}$ & Yes & Unclear & Unclear & Unclear & No & No & Yes & Yes & No & Fair \\
\hline & $\begin{array}{l}\text { Parpouchi, } \\
2018^{12}\end{array}$ & Yes & Unclear & Yes & Unclear & No & No & No & Unclear & Yes & Fair \\
\hline
\end{tabular}


Table 2. Quality ratings for contingency management

\begin{tabular}{|c|c|c|c|c|c|c|c|c|c|c|}
\hline $\begin{array}{l}\text { Author, } \\
\text { Year }\end{array}$ & Randomization & $\begin{array}{c}\text { Allocation } \\
\text { Concealment }\end{array}$ & $\begin{array}{c}\text { Groups } \\
\text { Similar at } \\
\text { Baseline }\end{array}$ & $\begin{array}{c}\text { Blinded } \\
\text { Outcome } \\
\text { Assessors }\end{array}$ & $\begin{array}{l}\text { Blinded } \\
\text { Care } \\
\text { Provider }\end{array}$ & $\begin{array}{l}\text { Blinded } \\
\text { Patient }\end{array}$ & $\begin{array}{l}\text { Intention- } \\
\text { To-Treat } \\
\text { (ITT) } \\
\text { Analysis }\end{array}$ & $\begin{array}{l}\text { Acceptable } \\
\text { Levels of } \\
\text { Overall } \\
\text { Attrition }\end{array}$ & $\begin{array}{c}\begin{array}{c}\text { Avoidance } \\
\text { of } \\
\text { Selective } \\
\text { Outcomes } \\
\text { Reporting }\end{array} \\
\end{array}$ & $\begin{array}{c}\text { Final } \\
\text { Quality } \\
\text { Rating }\end{array}$ \\
\hline $\begin{array}{l}\text { DeFulio, } \\
2012^{14}\end{array}$ & Yes & Unclear & Yes & Unclear & No & No & Yes & Yes & Yes & Fair \\
\hline $\begin{array}{l}\text { Dunn, } \\
2013^{15}\end{array}$ & Yes & Unclear & Yes & Unclear & No & No & Yes & Yes & Yes & Fair \\
\hline $\begin{array}{l}\text { Dunn, } \\
2015^{16}\end{array}$ & Yes & Unclear & No & Unclear & No & No & Yes & Yes & Yes & Fair \\
\hline $\begin{array}{l}\text { Epstein, } \\
2009^{17}\end{array}$ & Yes & Yes & Yes & Yes & Yes & Yes & Yes & Yes & Yes & Good \\
\hline $\begin{array}{l}\text { Everly, } \\
2011^{18}\end{array}$ & Yes & Unclear & Yes & Unclear & Unclear & No & Yes & Yes & Yes & Fair \\
\hline $\begin{array}{l}\text { Holtyn, } \\
2014^{19}\end{array}$ & Yes & No & Unclear & Unclear & No & No & Yes & Yes & No & Fair \\
\hline $\begin{array}{l}\text { Kidorf, } \\
2018^{11}\end{array}$ & Yes & Unclear & Unclear & Unclear & No & No & Yes & Yes & No & Fair \\
\hline $\begin{array}{l}\text { Specka, } \\
2013^{20}\end{array}$ & Unclear & Unclear & Unclear & No & No & No & Yes & Yes & Yes & Fair \\
\hline
\end{tabular}


Table 3a. Quality ratings for health IT RCTs

\begin{tabular}{|c|c|c|c|c|c|c|c|c|c|c|}
\hline $\begin{array}{l}\text { Author, } \\
\text { Year }\end{array}$ & Randomization & $\begin{array}{c}\text { Allocation } \\
\text { Concealment }\end{array}$ & $\begin{array}{c}\text { Groups } \\
\text { Similar at } \\
\text { Baseline }\end{array}$ & $\begin{array}{c}\text { Blinded } \\
\text { Outcome } \\
\text { Assessors }\end{array}$ & $\begin{array}{c}\text { Blinded Care } \\
\text { Provider }\end{array}$ & $\begin{array}{l}\text { Blinded } \\
\text { Patient }\end{array}$ & $\begin{array}{l}\text { Intention- } \\
\text { To-Treat } \\
\text { (ITT) } \\
\text { Analysis }\end{array}$ & $\begin{array}{c}\text { Acceptable } \\
\text { Levels of } \\
\text { Overall } \\
\text { Attrition }\end{array}$ & $\begin{array}{c}\begin{array}{c}\text { Avoidance } \\
\text { of } \\
\text { Selective }\end{array} \\
\text { Outcomes } \\
\text { Reporting }\end{array}$ & $\begin{array}{c}\text { Final } \\
\text { Quality } \\
\text { Rating }\end{array}$ \\
\hline $\begin{array}{l}\text { Marsch, } \\
2014^{21}\end{array}$ & Yes & No & Yes & Yes & No & No & Yes & Yes & Unclear & Fair \\
\hline $\begin{array}{l}\text { Moore, } \\
2019^{22}\end{array}$ & Unclear & No & Unclear & No & No & No & Yes & Yes & Unclear & Poor \\
\hline $\begin{array}{l}\text { Reutsch, } \\
2012^{23}\end{array}$ & Yes & Unclear & Yes & Unclear & Unclear & Unclear & Unclear & Yes & Yes & Fair \\
\hline $\begin{array}{l}\text { Shi, } \\
2019^{24}\end{array}$ & Yes & Unclear & Yes & Unclear & No & No & Yes & Yes & Yes & Fair \\
\hline
\end{tabular}

Table 3b. Quality ratings for health IT cohort studies

\begin{tabular}{|c|c|c|c|c|c|c|c|c|c|c|}
\hline $\begin{array}{l}\text { Author, } \\
\text { Year }\end{array}$ & Randomization & $\begin{array}{l}\text { Allocation } \\
\text { Concealment }\end{array}$ & $\begin{array}{l}\text { Groups } \\
\text { Similar at } \\
\text { Baseline }\end{array}$ & $\begin{array}{l}\text { Blinded } \\
\text { Outcome } \\
\text { Assessors }\end{array}$ & $\begin{array}{l}\text { Blinded } \\
\text { Care } \\
\text { Provider }\end{array}$ & $\begin{array}{l}\text { Blinded } \\
\text { Patient }\end{array}$ & $\begin{array}{l}\text { Intention- } \\
\text { To-Treat } \\
\text { (ITT) } \\
\text { Analysis }\end{array}$ & $\begin{array}{l}\text { Acceptable } \\
\text { Levels of } \\
\text { Overall } \\
\text { Attrition }\end{array}$ & $\begin{array}{l}\text { Avoidance } \\
\text { of Selective } \\
\text { Outcomes } \\
\text { Reporting }\end{array}$ & $\begin{array}{l}\text { Final } \\
\text { Quality } \\
\text { Rating }\end{array}$ \\
\hline $\begin{array}{l}\text { Eibl, } \\
2017^{25}\end{array}$ & $\mathrm{~N} / \mathrm{A}$ & Yes & Yes & No & No & No & No & Unclear & Yes & Fair \\
\hline $\begin{array}{l}\text { Weintraub, } \\
2018^{26}\end{array}$ & $\mathrm{~N} / \mathrm{A}$ & Yes & Yes & No & No & No & No & Unclear & Yes & Fair \\
\hline $\begin{array}{l}\text { Zheng, } \\
2017^{27}\end{array}$ & N/A & Yes & Yes & No & No & No & Yes & Unclear & Yes & Fair \\
\hline
\end{tabular}


Table 4. Quality ratings for extended-release medication based treatments

\begin{tabular}{|c|c|c|c|c|c|c|c|c|c|c|}
\hline $\begin{array}{l}\text { Author, } \\
\text { Year }\end{array}$ & Randomization & $\begin{array}{c}\text { Allocation } \\
\text { Concealment }\end{array}$ & $\begin{array}{l}\text { Groups } \\
\text { Similar at } \\
\text { Baseline }\end{array}$ & $\begin{array}{c}\text { Blinded } \\
\text { Outcome } \\
\text { Assessors }\end{array}$ & $\begin{array}{l}\text { Blinded } \\
\text { Care } \\
\text { Provider }\end{array}$ & $\begin{array}{l}\text { Blinded } \\
\text { Patient }\end{array}$ & $\begin{array}{l}\text { Intention- } \\
\text { To-Treat } \\
\text { (ITT) } \\
\text { Analysis }\end{array}$ & $\begin{array}{c}\text { Acceptable } \\
\text { Levels of } \\
\text { Overall } \\
\text { Attrition }\end{array}$ & $\begin{array}{c}\text { Avoidance } \\
\text { of } \\
\text { Selective } \\
\text { Outcomes } \\
\text { Reporting }\end{array}$ & $\begin{array}{c}\text { Final } \\
\text { Quality } \\
\text { Rating }\end{array}$ \\
\hline $\begin{array}{l}\text { Tanum, } \\
2017^{28}\end{array}$ & Yes & Yes & Yes & Yes & No & No & Yes & Yes & Yes & Good \\
\hline $\begin{array}{l}\text { Lee, } \\
2018^{29}\end{array}$ & Yes & Yes & Yes & Unclear & Unclear & Unclear & Yes & No & Yes & Fair \\
\hline $\begin{array}{l}\text { Sullivan, } \\
2019^{30}\end{array}$ & Yes & Unclear & Yes & No & No & No & Yes & Yes & Yes & Fair \\
\hline $\begin{array}{l}\text { Rosenthal, } \\
2016^{34}\end{array}$ & Yes & Yes & Yes & Yes & Yes & Yes & Yes & Yes & Yes & Good \\
\hline $\begin{array}{l}\text { Lofwall, } \\
2018^{35}\end{array}$ & Yes & Yes & Yes & Unclear & Unclear & Unclear & Yes & No & Yes & Fair \\
\hline
\end{tabular}


Table 5. Quality ratings for psychosocial

\begin{tabular}{|c|c|c|c|c|c|c|c|c|c|c|}
\hline $\begin{array}{l}\text { Author, } \\
\text { Year }\end{array}$ & Randomization & $\begin{array}{c}\text { Allocation } \\
\text { Concealment }\end{array}$ & $\begin{array}{l}\text { Groups } \\
\text { Similar at } \\
\text { Baseline }\end{array}$ & $\begin{array}{l}\text { Blinded } \\
\text { Outcome } \\
\text { Assessors }\end{array}$ & $\begin{array}{l}\text { Blinded } \\
\text { Care } \\
\text { Provider }\end{array}$ & $\begin{array}{l}\text { Blinded } \\
\text { Patient }\end{array}$ & $\begin{array}{l}\text { Intention- } \\
\text { To-Treat } \\
\text { (ITT) } \\
\text { Analysis }\end{array}$ & $\begin{array}{l}\text { Acceptable } \\
\text { Levels of } \\
\text { Overall } \\
\text { Attrition }\end{array}$ & $\begin{array}{c}\text { Avoidance } \\
\text { of } \\
\text { Selective } \\
\text { Outcomes } \\
\text { Reporting }\end{array}$ & $\begin{array}{c}\text { Final } \\
\text { Quality } \\
\text { Rating }\end{array}$ \\
\hline $\begin{array}{l}\text { Christensen, } \\
2014^{36}\end{array}$ & No & No & No & No & No & No & Unclear & No & Yes & Poor \\
\hline $\begin{array}{l}\text { Fiellin, } \\
2013^{37}\end{array}$ & Yes & Yes & Yes & Unclear & No & No & Yes & Yes & Yes & Good \\
\hline $\begin{array}{l}\text { Jaffray, } \\
2014^{38}\end{array}$ & Unclear & Unclear & Yes & Unclear & No & Yes & Yes & No & Yes & Poor \\
\hline $\begin{array}{l}\text { Marsden, } \\
2019^{39}\end{array}$ & Yes & No & Yes & No & No & No & Yes & Yes & Yes & Fair \\
\hline $\begin{array}{l}\text { Mitchell, } \\
2013^{40}\end{array}$ & Yes & Yes & No & Unclear & No & No & Yes & No & Unclear & Poor \\
\hline $\begin{array}{l}\text { Schwartz, } \\
2012^{41}\end{array}$ & Yes & Unclear & Yes & Unclear & No & No & Yes & No & Yes & Fair \\
\hline $\begin{array}{l}\text { Stein, } \\
2015^{42}\end{array}$ & Yes & Yes & Yes & Yes & No & No & Yes & Yes & Yes & Good \\
\hline $\begin{array}{l}\text { Sullivan, } \\
2015\end{array}$ & Unclear & Yes & Yes & Unclear & No & Yes & Unclear & No & Yes & Fair \\
\hline $\begin{array}{l}\text { Weiss, } \\
2011^{44}\end{array}$ & Unclear & Unclear & Yes & No & No & No & Yes & Yes & Yes & Fair \\
\hline
\end{tabular}




\section{References}

1. Hedrich D, Alves P, Farrell M, et al. The effectiveness of opioid maintenance treatment in prison settings: a systematic review. Addiction. 2012;107(3):501-17. doi: https://dx.doi.org/10.1111/j.13600443.2011.03676.x. PMID: 21955033.

2. $\quad$ Friedmann PD, Wilson D, Hoskinson R, Jr., et al. Initiation of extended release naltrexone (XR-NTX) for opioid use disorder prior to release from prison. J Subst Abuse Treat. 2018;85:45-8. doi: https://dx.doi.org/10.1016/j.jsat.2017.04.010 . PMID: 28527855.

3. Gordon MS, Kinlock TW, Schwartz RP, et al. A randomized clinical trial of buprenorphine for prisoners: Findings at 12months post-release. Drug Alcohol Depend. 2017;172:34-42. doi:

https://dx.doi.org/10.1016/j.drugalcdep.2016 .11.037. PMID: 28107680.

4. Brooner RK, Kidorf MS, King VL, et al. Managing psychiatric comorbidity within versus outside of methadone treatment settings: a randomized and controlled evaluation. Addiction. 2013;108(11):194251. doi: https://dx.doi.org/10.1111/add.12269. PMID: 23734943.

5. Carrieri PM, Michel L, Lions C, et al. Methadone induction in primary care for opioid dependence: a pragmatic randomized trial (ANRS Methaville). PLoS ONE [Electronic Resource]. 2014;9(11):e112328. doi:

https://dx.doi.org/10.1371/journal.pone.0112 328. PMID: 25393311.

6. Miotto K, Hillhouse M, Donovick R, et al. Comparison of buprenorphine treatment for opioid dependence in 3 settings. J Addict Med. 2012;6(1):68-76. doi: https://dx.doi.org/10.1097/ADM.0b013e318 233d621. PMID: 22105061.

7. Liebschutz JM, Crooks D, Herman D, et al. Buprenorphine treatment for hospitalized, opioid-dependent patients: a randomized clinical trial. JAMA Intern Med. 2014;174(8):1369-76. doi: https://dx.doi.org/10.1001/jamainternmed.20 14.2556. PMID: 25090173.
D'Onofrio G, Chawarski MC, O'Connor PG, et al. Emergency Department-Initiated Buprenorphine for Opioid Dependence with Continuation in Primary Care: Outcomes During and After Intervention. Journal of General Internal Medicine. 2017;32(6):6606. doi: https://dx.doi.org/10.1007/s11606017-3993-2. PMID: 28194688.

9. Schwartz RP, Kelly SM, Mitchell SG, et al. Patient-centered methadone treatment: a randomized clinical trial. Addiction. 2017;112(3):454-64. doi: https://dx.doi.org/10.1111/add.13622. PMID: 27661788.

10. Beattie A, Marques EM, Barber M, et al. Script in a Day intervention for individuals who are injecting opioids: a feasibility randomized control trial. J Public Health (Oxf). 2015;38(4):712-21. doi: https://dx.doi.org/10.1093/pubmed/fdv161. PMID: 28158697

11. Kidorf M, Brooner RK, Leoutsakos JM, et al. Treatment initiation strategies for syringe exchange referrals to methadone maintenance: A randomized clinical trial. Drug Alcohol Depend. 2018;187:343-50. doi:

https://dx.doi.org/10.1016/j.drugalcdep.2018 .03.009. PMID: 29709732.

12. Parpouchi M, Moniruzzaman A, Rezansoff SN, et al. The effect of Housing First on adherence to methadone maintenance treatment. Int J Drug Policy. 2018;56:73-80. doi:

https://dx.doi.org/10.1016/j.drugpo.2018.03. 012. PMID: 29609153.

13. Amato L, Minozzi S, Davoli M, et al. Psychosocial combined with agonist maintenance treatments versus agonist maintenance treatments alone for treatment of opioid dependence. Cochrane Database Syst Rev. 2011(10):CD004147. doi: https://dx.doi.org/10.1002/14651858.CD004 147.pub4. PMID: 21975742. 
14. DeFulio A, Everly JJ, Leoutsakos JM, et al. Employment-based reinforcement of adherence to an FDA approved extended release formulation of naltrexone in opioiddependent adults: a randomized controlled trial. Drug Alcohol Depend. 2012;120(13):48-54. doi: https://dx.doi.org/10.1016/j.drugalcdep.2011 .06.023. PMID: 21782353.

15. Dunn KE, Defulio A, Everly JJ, et al. Employment-based reinforcement of adherence to oral naltrexone treatment in unemployed injection drug users. Exp Clin Psychopharmacol. 2013;21(1):74-83. doi: https://dx.doi.org/10.1037/a0030743. PMID: 23205722.

16. Dunn K, DeFulio A, Everly JJ, et al. Employment-based reinforcement of adherence to oral naltrexone in unemployed injection drug users: 12-month outcomes. Psychol Addict Behav. 2015 Jun;29(2):2706. doi: https://dx.doi.org/10.1037/adb0000010. PMID: 25134047.

17. Epstein DH, Schmittner J, Umbricht A, et al. Promoting abstinence from cocaine and heroin with a methadone dose increase and a novel contingency. Drug Alcohol Depend. 2009;101(1-2):92-100. doi: https://dx.doi.org/10.1016/j.drugalcdep.2008 11.006. PMID: 19101098.

18. Everly JJ, DeFulio A, Koffarnus MN, et al. Employment-based reinforcement of adherence to depot naltrexone in unemployed opioid-dependent adults: a randomized controlled trial. Addiction. 2011;106(7):1309-18. doi: https://dx.doi.org/10.1111/j.13600443.2011.03400.x. PMID: 21320227.

19. Holtyn AF, Koffarnus MN, DeFulio A, et al. The therapeutic workplace to promote treatment engagement and drug abstinence in out-of-treatment injection drug users: a randomized controlled trial. Prev Med. 2014 Nov;68:62-70. doi: https://dx.doi.org/10.1016/j.ypmed.2014.02. 021. PMID: 24607365.
20. Specka M, Boning A, Kluwig J, et al. Can reinforcement-based interventions to reduce drug use successfully be adapted to routine opioid maintenance treatment? Ann Ist Super Sanita. 2013;49(4):358-64. doi: https://dx.doi.org/10.4415/ANN_13_04_07. PMID: 24334780.

21. Marsch LA, Guarino H, Acosta M, et al. Web-based behavioral treatment for substance use disorders as a partial replacement of standard methadone maintenance treatment. J Subst Abuse Treat. 2014;46(1):43-51. doi: https://dx.doi.org/10.1016/j.jsat.2013.08.012 . PMID: 24060350.

22. Moore BA, Buono FD, Lloyd DP, et al. A randomized clinical trial of the Recovery Line among methadone treatment patients with ongoing illicit drug use. J Subst Abuse Treat. 2019;97:68-74. doi:

https://dx.doi.org/10.1016/j.jsat.2018. PMID: 30577901.

23. Ruetsch C, Tkacz J, McPherson TL, et al The effect of telephonic patient support on treatment for opioid dependence: outcomes at one year follow-up. Addictive Behaviors. 2012;37(5):686-9. doi:

https://dx.doi.org/10.1016/j.addbeh.2012.01. 013. PMID: 22348921.

24. Shi JM, Henry SP, Dwy SL, et al. Randomized pilot trial of Web-based cognitive-behavioral therapy adapted for use in office-based buprenorphine maintenance. Subst Abuse. 2019:1-4. doi: https://dx.doi.org/10.1080/08897077.2019.1 569192. PMID: 30714880.

25. Eibl JK, Gauthier G, Pellegrini D, et al. The effectiveness of telemedicine-delivered opioid agonist therapy in a supervised clinical setting. Drug Alcohol Depend. 2017;176:133-8. doi: https://dx.doi.org/10.1016/j.drugalcdep.2017 .01.048. PMID: 28535455.

26. Weintraub E, Greenblatt AD, Chang J, et al. Expanding access to buprenorphine treatment in rural areas with the use of telemedicine. Am J Addict. 2018;27(8):6127. doi: https://dx.doi.org/10.1111/ajad.12805. PMID: 30265425 
27. Zheng W, Nickasch M, Lander L, et al. Treatment Outcome Comparison Between Telepsychiatry and Face-to-face Buprenorphine Medication-assisted Treatment for Opioid Use Disorder: A 2Year Retrospective Data Analysis. J Addict Med. 2017;11(2):138-44. doi: https://dx.doi.org/10.1097/ADM.000000000 0000287. PMID: 28107210.

28. Tanum L, Solli KK, Latif ZE, et al. Effectiveness of Injectable ExtendedRelease Naltrexone vs Daily BuprenorphineNaloxone for Opioid Dependence: A Randomized Clinical Noninferiority Trial. JAMA Psychiatry. 2017;74(12):1197-205. doi: https://dx.doi.org/10.1001/jamapsychiatry.2 017.3206. PMID: 29049469.

29. Lee JD, Nunes EV, Jr., Novo P, et al. Comparative effectiveness of extendedrelease naltrexone versus buprenorphinenaloxone for opioid relapse prevention (X:BOT): a multicentre, open-label, randomised controlled trial. Lancet. 2018;391(10118):309-18. doi: https://dx.doi.org/10.1016/S01406736(17)32812-X. PMID: 29150198.

30. Sullivan MA, Bisaga A, Pavlicova M, et al. A Randomized Trial Comparing ExtendedRelease Injectable Suspension and Oral Naltrexone, Both Combined With Behavioral Therapy, for the Treatment of Opioid Use Disorder. Am J Psychiatry. 2019;176(2):129-37. doi: https://dx.doi.org/10.1176/appi.ajp.2018.170 70732. PMID: 30336703.

31. Krupitsky E, Zvartau E, Blokhina E, et al. Randomized trial of long-acting sustainedrelease naltrexone implant vs oral naltrexone or placebo for preventing relapse to opioid dependence. Arch Gen Psychiatry. 2012;69(9):973-81. doi: https://dx.doi.org/10.1001/archgenpsychiatr y.2012.1a. PMID: 22945623.

32. Strang J, Kelleher M, Mayet S, et al. Extended-release naltrexone versus standard oral naltrexone versus placebo for opioid use disorder: the NEAT three-arm RCT. Health Technol Assess. 2019;23(3):1-72. doi: https://dx.doi.org/10.3310/hta23030. PMID: 30702059.
33. Lobmaier PP, Kunoe N, Gossop M, et al. Naltrexone implants compared to methadone: outcomes six months after prison release. Eur Addict Res. 2010;16(3):139-45. doi: https://dx.doi.org/10.1159/000313336. PMID: 20424458.

34. Rosenthal RN, Lofwall MR, Kim S, et al. Effect of Buprenorphine Implants on Illicit Opioid Use Among Abstinent Adults With Opioid Dependence Treated With Sublingual Buprenorphine: A Randomized Clinical Trial. JAMA. 2016;316(3):282-90. doi:

https://dx.doi.org/10.1001/jama.2016.9382. PMID: 27434441.

35. Lofwall MR, Walsh SL, Nunes EV, et al. Weekly and Monthly Subcutaneous Buprenorphine Depot Formulations vs Daily Sublingual Buprenorphine With Naloxone for Treatment of Opioid Use Disorder: A Randomized Clinical Trial. JAMA Intern Med. 2018;178(6):764-73. doi: https://dx.doi.org/10.1001/jamainternmed.20 18.1052. PMID: 29799968.

36. Christensen DR, Landes RD, Jackson L, et al. Adding an Internet-delivered treatment to an efficacious treatment package for opioid dependence. J Consult Clin Psychol. 2014;82(6):964-72. doi: https://dx.doi.org/10.1037/a0037496. PMID: 25090043.

37. Fiellin DA, Barry DT, Sullivan LE, et al. A randomized trial of cognitive behavioral therapy in primary care-based buprenorphine. Am J Med. 2013;126(1):74.e11-7. doi: https://dx.doi.org/10.1016/j.amjmed.2012.07 .005. PMID: 23260506.

38. Jaffray M, Matheson C, Bond CM, et al. Does training in motivational interviewing for community pharmacists improve outcomes for methadone patients? A cluster randomised controlled trial. Int J Pharm Pract. 2014;22(1):4-12. doi: https://dx.doi.org/10.1111/ijpp.12049. PMID: 23822820. 
39. Marsden J, Stillwell G, James K, et al. Efficacy and cost-effectiveness of an adjunctive personalised psychosocial intervention in treatment-resistant maintenance opioid agonist therapy: a pragmatic, open-label, randomised controlled trial. Lancet Psychiatry. 2019;6(5):391-402. doi:

https://dx.doi.org/10.1016/S22150366(19)30097-5. PMID: 30952568.

40. Mitchell SG, Gryczynski J, Schwartz RP, et al. A randomized trial of intensive outpatient (IOP) vs. standard outpatient (OP) buprenorphine treatment for African Americans. Drug Alcohol Depend. 2013;128(3):222-9. doi: https://dx.doi.org/10.1016/j.drugalcdep.2012 .08.027. PMID: 22999817.

41. Schwartz RP, Kelly SM, O'Grady KE, et al. Randomized trial of standard methadone treatment compared to initiating methadone without counseling: 12-month findings. Addiction. 2012;107(5):943-52. doi: https://dx.doi.org/10.1111/j.13600443.2011.03700.x. PMID: 22029398.

42. Stein MD, Herman DS, Moitra E, et al. A preliminary randomized controlled trial of a distress tolerance treatment for opioid dependent persons initiating buprenorphine. Drug Alcohol Depend. 2015;147:243-50.

doi:

https://dx.doi.org/10.1016/j.drugalcdep.2014 .11.007. PMID: 25510307.

43. Sullivan MA, Bisaga A, Glass A, et al. Opioid use and dropout in patients receiving oral naltrexone with or without single administration of injection naltrexone. Drug Alcohol Depend. 2015;147:122-9. doi: https://dx.doi.org/10.1016/j.drugalcdep.2014 11.028. PMID: 25555621.

44. Weiss RD, Potter JS, Fiellin DA, et al. Adjunctive counseling during brief and extended buprenorphine-naloxone treatment for prescription opioid dependence: a 2phase randomized controlled trial. Arch Gen Psychiatry. 2011;68(12):1238-46. doi: https://dx.doi.org/10.1001/archgenpsychiatr y.2011.121. PMID: 22065255 